NBER WORKING PAPER SERIES

\title{
THE EFFECTS OF THE TAX DEDUCTION FOR POSTSECONDARY TUITION: IMPLICATIONS FOR STRUCTURING TAX-BASED AID
}

\author{
Caroline M. Hoxby \\ George B. Bulman \\ Working Paper 21554 \\ http://www.nber.org/papers/w21554 \\ NATIONAL BUREAU OF ECONOMIC RESEARCH \\ 1050 Massachusetts Avenue \\ Cambridge, MA 02138 \\ September 2015
}

The opinions expressed in this paper are those of the authors alone and do not necessarily represent the views of the U.S. Internal Revenue Service, the U.S. Department of the Treasury, or the National Bureau of Economic Research. This work is a component of a larger project examining the effects of federal tax expenditures and on-budget expenditures related to higher education. Selected, de-identified data were accessed through contract TIR-NO-12-P-00378 with the Statistics of Income (SOI) Division at the U.S. Internal Revenue Service. The authors gratefully acknowledge the help of Barry W. Johnson and Michael Weber of the Statistics of Income Division, Internal Revenue Service. The authors acknowledge very useful comments from Judith Scott-Clayton and Bruce Sacerdote. They also acknowledge help from John Friedman, Raj Chetty, Emmanuel Saez, and Daniel Yagan.

NBER working papers are circulated for discussion and comment purposes. They have not been peerreviewed or been subject to the review by the NBER Board of Directors that accompanies official NBER publications.

(C) 2015 by Caroline M. Hoxby and George B. Bulman. All rights reserved. Short sections of text, not to exceed two paragraphs, may be quoted without explicit permission provided that full credit, including (C) notice, is given to the source. 
The Effects of the Tax Deduction for Postsecondary Tuition: Implications for Structuring

Tax-Based Aid

Caroline M. Hoxby and George B. Bulman

NBER Working Paper No. 21554

September 2015

JEL No. C21,C55,H2,H24,H26,I22,I23,I26

\begin{abstract}
The federal tax deduction for tuition potentially increases investments in postsecondary education at minimal administrative cost. We assess whether it actually does this using regression discontinuity methods on the income cutoffs that govern eligibility for the deduction. Although many eligible households take nearly the maximum deduction allowed, we find no evidence that it affects attending college (at all), attending full- versus part-time, attending four- versus two-year college, the resources experienced in college, the amount paid for college, or student loans. Our analysis suggests that the deduction's inefficacy may be due to issues of salience, timing, and the method of receipt. We argue that the deduction might increase college-going if it were modified in simple ways that would not increase costs but would make it more likely to relax liquidity constraints and be perceived as a price change (which they is) as opposed to an income change. We outline how such modifications could be tested. This study has independent applied econometrics interest because households who would be just above a cut-off manage their incomes so that they fall slightly below it. This income management generates bias due to reverse causality, and we explore how to choose "doughnut-holes" that avoid bias without undue loss of statistical power.
\end{abstract}

\author{
Caroline M. Hoxby \\ Department of Economics \\ Stanford University \\ Landau Building, 579 Serra Mall \\ Stanford, CA 94305 \\ and NBER \\ choxby@stanford.edu \\ George B. Bulman \\ Department of Economics \\ University of California \\ 1156 High Street \\ Santa Cruz, CA 95064 \\ gbulman@ucsc.edu
}




\section{Introduction}

The U.S. federal government has a somewhat bewildering array of programs that help families pay for higher education. Some of these programs, such as the Pell grant for low-income students, receive significant media attention and appear to be salient to families. Others, especially those that operate through the tax code, are less in the public eye. However, all of these programs have the goal of causing people to acquire additional higher education by reducing the price of college and relaxing liquidity constraints. They are usually justified with a return-on-investment argument: By causing people to attain more education than they otherwise would, society benefits because people earn more, pay sufficiently more taxes to finance the programs, and are better citizens in myriad ways. All these arguments depend, however, on the programs' having positive causal effects on college-going. In this paper, we investigate one of the key tax expenditures for higher education: the above-the-line deduction for tuition and fees (DTF). The DTF has features--sharp eligibility cut-offs based on household income--that make it highly susceptible to causal analysis. Since we find no evidence that the DTF has a causal effect on any measure of college-going, we apply economic logic to its structure to explain the likely reasons why it is inefficacious. For instance, we argue that the DTF may perceived as a change in income rather than a change in the price of college (which it actually is). If it is perceived as a change in income, its effect would be negligible, consistent with our results. We suggest simple modifications to the DTF that would not change its cost but that would likely make it more efficacious. We outline how such modifications could be tested.

This study has independent applied econometrics interest because our data are so dense and precise that it is a near perfect application for exploring "doughnut-holes" as a remedy for manipulation of a forcing variable in regression discontinuity analysis. Because estimates of the DTF suffer from reverse causality bias if we do not account for households' tendency to manage their incomes to get slightly below the cutoffs, we produce unbiased causal estimates by applying a statistically appropriate doughnut-hole to each cut-off.

It is reasonable to ask why the federal government has both grant-based and tax-based programs that support individuals' spending on higher education. Programs that operate through the tax code, like the DTF, have the advantage of extremely low paperwork and administrative costs. Form 8917, which a family files for the DTF, has only 6 questions and could take at most a few minutes to complete. In contrast, the Free Application for Federal Student Aid (FAFSA), required for the grant programs, has 105 questions and is time-consuming to complete. To help the Internal Revenue Service (IRS) administer the tax expenditures for higher education, schools issue a 1098-T for every student. But, the cost of doing this plus the IRS's costs of processing the extra lines in the tax code, even if very generously estimated, could not possibly represent more than 0.1 percent of the tax expenditures. In contrast, each college and the U.S. Department of Education maintains an office to administer federal grant aid, and cost of running these offices appears to amount to 10 percent of the total spent on grants. There are also concerns that schools commit fraud when administering grant-based aid. ${ }^{4}$

The negligible cost of administering a tax-based aid program like the DTF is undoubtedly

\footnotetext{
${ }^{4}$ The estimate of the cost of administering federal grant aid is based on authors' calculations. The U.S. Department of Education's budget indicates that the federal administrative cost amounts to about $4.3 \%$ of the total spent on grants. The budgets of higher education institutions suggest that their cost of administering financial aid amounts to about $5.4 \%$ of grants. For the concerns about fraud, see for instance U.S. General Accountability Office (2010).
} 
an advantage, but it may have disadvantages owing its superficial aspects. If a family pays tuition and fees with typical timing, it receives its tax-based aid an average of 10.5 months later. This timing may make the tax-based aid less likely to relax liquidity constraints than grant-based aid which is timed to coordinate with tuition bills. In addition, because tax rules are complex, families may not understand that they are eligible for tax-based aid when they are making college-going decisions. Such non-recognition may limit the causal impact of the programs on educational attainment. In particular, families may fail to perceive the aid as a change in the price of college (which it is) and may instead perceive it as income. If they perceive it as income, the effects of the aid are likely to be negligible. We show that a reasonable upper bound on the income effect of the DTF is an increase in college attendance of a tiny 0.25 percentage points (a quarter of 1 percentage point).

In short, understanding the causal effects of the DTF is both feasible and important. If tax-based aid causally increases college-going, its administrative costs are so low that it might be wise to substitute it for grant-based aid. If the DTF has little or no effect on college-going, economic logic may suggest how the DTF could be modified to increase its causal effects without increasing its potential costs. This is an unusual win-win situation.

We believe this paper contributes in four ways. First, the DTF is an important tax-based aid program that has received virtually no evaluation. ${ }^{5}$ Second, because the DTF lends itself to regression discontinuity analysis and because we employ nearly ideal administrative data, our estimates are precise and bias-free under assumptions that we are able to validate well. Third, our analysis suggests that apparently superficial aspects of the program--its salience, timing, the way it is presented, the way it is received--may crucially change its effects. This is why we may be able to restructure the DTF to make it attain its intended effect without increasing its cost. Finally, our study is ideal for investigating manipulation of the forcing variable and the use of doughnut-holes in regression discontinuity analysis. Although we did not begin this study in an effort to learn about optimal doughnut-holes, our results could inform any such analysis.

The main limitation of this study is that our estimates of the effect of the DTF are local to households with income in the vicinity of one of the eligibility thresholds. ${ }^{6}$ Fortunately, there are several thresholds--as low as $\$ 65,000$ and as high as $\$ 180,000-$-so we do not rely on households in a narrow income range.

In section 2 of this paper, we explain how the DTF works. Section 3 describes our data and the college-going context. Section 4 reviews the regression discontinuity method. We discuss income management and statistically appropriate doughnut-holes in section 5. In section 6, we consider how households perceive the DTF and what this behavioral economics implies for analysis. In section 7, we estimate the DTF's causal effect on numerous college-related outcomes including attendance, college choice, instructional resources, tuition paid, and student loans. In section 8 , we summarize our findings and explain why we should not be surprised that DTF has negligible effects on college-going. In section 9, we posit that simple revisions to the

\footnotetext{
5 For analysis of the federal tax credits for higher education, see Bulman and Hoxby (2015), Turner (2011), Long (2004), Hoxby (1998), and Maag and Rohaly (1997).

6 The most credible studies that examine the effect of grant aid rely on randomization or regression discontinuity. They also produce effects that are local. For instance, most random assignment occurs only among students who are marginal to the program along some dimension such as achievement or family income.
} 
DTF might increase its effects. We propose a rigorous test of these revisions.

\section{The Tax Deduction for Tuition and Fees}

The DTF was enacted as part of the Economic Growth and Tax Relief Reconciliation Act of 2001 (P.L. 107-16). It remains in force today although currently it is less used because the American Opportunity Tax Credit (AOTC), a temporary higher education tax credit enacted in 2009 as part of the Economic Stimulus, is more generous for full-time undergraduate students in many circumstances. ${ }^{7}$ Since a family cannot take both the DTF and one of the higher education tax credits, tax expenditures on the DTF will remain unusually small until 2017 when the AOTC expires. At that time, projecting from pre-AOTC costs, the DTF will be a tax expenditure of about $\$ 4$ billion each year. We focus our analysis on the pre-AOTC tax years (2002 to 2008) because that period reveals the effects of the deduction in a normal year when temporary measures like the AOTC were irrelevant.

Under the DTF, a household that pays tuition and fees for undergraduate or graduate education is eligible to deduct that payment, up to some maximum, from gross income. ${ }^{8}$ The deduction is above-the-line, meaning that the households need not itemize deductions to take the DTF. Eligibility for the DTF depends on a household's modified adjusted gross income (MAGI) which is equal to total income minus all of the other above-the-line deductions. ${ }^{9}$ In 2002 and 2003, joint-filing households with MAGI less than or equal to $\$ 130,000$ and single-filing households with MAGI less than or equal to $\$ 65,000$ were eligible for a $\$ 3,000$ deduction. In 2004, a two threshold system was adopted and the maximum deduction was increased. Joint filers with MAGI less than or equal to $\$ 130,000$ and single filers with MAGI less than or equal to $\$ 65,000$ were eligible for a $\$ 4,000$ deduction. Joint filers with MAGI greater than $\$ 130,000$ but less than or equal to $\$ 160,000$ and single filers with MAGI greater than $\$ 65,000$ but less than or equal to $\$ 80,000$ were eligible for a $\$ 2,000$ deduction. These rules remain in force as of 2015 . We thus have six distinct income cut-offs that can be used to identify the effects of the DTF.

The DTF income thresholds are tens of thousands of dollars distant from the thresholds for the higher education tax credits. This is important. Regression discontinuity-based estimates are based on an identification assumption of continuity. Therefore, the credibility of the estimates could be impaired by the presence of other policies that are discontinuous (have thresholds) in the bandwidths that are statistically relevant for the DTF. Fortunately, the tax

\footnotetext{
7 There was no DTF in the 2006 tax year, but the DTF was reinstated for 2007 and subsequent years. The Lifetime Learning tax credit can also be more generous than the DTF under certain circumstances

8 The deduction is per filer, not per student. The household itself must spend the money for tuition and fees. If some colleges expenses are paid by a tax-free scholarship, fellowship, grant, employer assistance, or veterans' assistance, the qualifying tuition and fees are reduced commensurately.

9 The DTF is computed after all of the other above-the-line deductions have been subtracted from total income. These other deductions vary slightly with the tax year but are: educator expenses, moving expenses, selfemployment taxes, alimony, IRA contributions, student loan interest, penalties on saving withdrawals, Archer medical savings accounts, Health Savings Accounts, self-employed health insurance, self-employed retirement accounts, and business expenses of reservists, performing artists, and certain others.
} 
credits have no such thresholds. ${ }^{10}$

The amount by which the DTF changes a household's tax liability depends on its marginal tax rate. For instance, if a 2004 household had income of $\$ 130,000$ and tuition and fees spending of $\$ 4,000$ or more, it would be eligible for a deduction of $\$ 4,000$. Its marginal tax rate in that year would have been 28 percent, so the DTF would have reduced its taxes by $\$ 1,120$ $(=0.28 \times 4000)$.

The DTF is for expenses paid in the tax year. For instance, a student might pay for the spring of her freshman year in January 2007 and pay for the fall of her sophomore year in September 2007. These two payments would generate a deduction on the taxes due on April 15, 2008. Thus, the tax-based aid associated with the January payment would be received about 12.5 to 16.5 months after the payment was made. The aid associated with the September payment would be received about 4.5 to 8.5 months after the payment was made. On average, households realize the DTF 10.5 months after making tuition payments.

If a household understands the DTF rules and anticipates how they will apply, the household will treat the DTF as a reduction in the price of higher education, which it is. A household that does not understand the DTF may treat it as an increase in income. Therefore, it is important to consider how well households understand the DTF rules.

If a household files its own taxes without software or a tax preparer, it must complete Form 8917 to take the DTF. The form makes the income eligibility cut-offs fairly obvious:

If the result [MAGI] is more than $\$ 80,000$ (\$160,000 if married filing jointly),

STOP. You cannot take the deduction for tuition and fees.

Slightly less obvious language divides filers into those who qualify for the two tiers of deductions:

Is the amount [MAGI] more than $\$ 65,000$ ( $\$ 130,000$ if married filing jointly)?

Yes. Enter the smaller of [tuition and fee spending] or $\$ 2,000$. No. Enter the smaller of [tuition and fee spending] or $\$ 4,000$.

The value of the DTF may be misunderstood even by households who complete Form 8917 since what they transfer to their main tax form is the amount of the deduction (for instance, $\$ 4,000)$. They may fail to understand that they need to multiply the deduction by their marginal tax rate to learn how much it reduces their taxes. Many people do not know their marginal, as opposed to their average, tax rate anyway.

Tax preparation software, such as Turbotax, obscures the DTF rules. Because a household with tuition and fee expenses is potentially eligible for several tax breaks, software first asks whether the household paid tuition and fees and then silently determines which, if any, tax break will benefit it most. Some software alerts a household that it is ineligible for tax-based aid even though it paid tuition and fees. At that point, the household might investigate the DTF rules or use trial and error (adding or subtracting income) to figure out whether it was close to a threshold. Because most software nudges filers to invest in an IRA at the end of the filing process, that nudge might also cause a household to realize that it was close to a DTF

\footnotetext{
${ }^{10}$ We choose bandwidths based on what is statistically appropriate. It just happens that these bandwidths never include thresholds relevant to the higher education tax credits.
} 
threshold. $^{11}$

Although human tax preparers are less mechanical than software, they tend to ask questions and convey information in a manner that is similar to software.

\section{Data, Cohorts and Years, the College-Going Context, and Income Dynamics} A. Data

We use de-identified data from an IRS database that are fully accurate and maximally dense. From Form 8917, we derive the qualified spending on tuition and fees that a tax filer claims. We derive relevant variables from returns: MAGI and filing status. Using data from information returns, we compute income and filing status even for non-filers. We use variables derived from Form 1098-T (the form on which institutions report payments of tuition and fees): tuition and fee payments, whether the student is enrolled at least half-time, whether the student is enrolled in graduate studies, and scholarships and grants received by the student. These variables are available regardless of whether a student actually takes tax-based aid for higher education. ${ }^{12} \mathrm{We}$ derive data on student loan interest from Form 1098-E. For data on colleges' characteristics (two- versus four-year, college resources), we rely on the National Center for Education Statistics' Integrated Postsecondary Education Data System (IPEDS).

\section{B. Cohorts and Years}

We describe individuals by their "cohort" based on the year in which they would graduate from high school if they entered primary school according to their state's compulsory schooling laws and progressed through school strictly on time. For instance the "2004 cohort" are the individuals expected to graduate from high school in June 2004. ${ }^{13}$ We hereafter call the cohort's expected graduation year "year 0, " the next year "year 1," and so on. Year 1 corresponds to the spring of freshman year and fall of sophomore year for people who progress through grade 12 strictly on time. It corresponds to the fall of freshman year for people who enter kindergarten late or otherwise graduate a year late, as about one-third of students do (Deming and Dynarski, 2008). As a factual matter, people are most likely to be enrolled in higher education in year 1 , followed closely by year 0 .

\section{The College-Going Context}

To put the DTF in context, we present relevant summary statistics in Table 1 which classifies households by MAGI. The MAGI intervals are narrower near the DTF thresholds to provide facts we need later. The table shows college attendance, tuition paid, and education resources experienced in year 1 for student from joint filing households in the 2004 cohort. It also shows

\footnotetext{
11 Davis (2002) and Turner (2012) suggest that the complexity of the higher education tax benefits may make eligible people fail to take the most advantageous benefit or to take a benefit at all.

12 In some cases, the 1098-T-derived variables generate a less than completely accurate calculation of the DTF for which the filer is eligible. In particular, a scholarship can pay for qualified tuition and fees but can also pay for other expenses such as room and board. Only the part of scholarship that pays for tuition and fees should be subtracted from the payment made by the student's family, but schools can report the entire scholarship on the 1098-T.

13 We use the compulsory schooling dates for each state to identify when a child would typically start school. For instance, a state might specify that any child who is age 6 by December 31 must be enrolled in the school year that begins in September of that calendar year.
} 
student loan interest paid in years 1 through 7 (2005 through 2011). We focus on the 2004 cohort because it is similar to the cohorts who would start college in 2002 and 2003 (potentially affected by the first version of the DTF) and to the cohorts who would start college in 2004 through 2008 (potentially affected by the second version of the DTF). Appendix Table 1 shows additional outcomes, such as scholarships and grants received, for the same students. Appendix Table 2 shows the full array of outcomes for students from single filing households.

Table 1 and Appendix Tables 1 and 2 reveal a few things that help us interpret our findings. First, there are many more joint filers near the income cut-offs than there are single filers. Second, college attendance (at all), four-year college attendance, college tuition paid, list tuition, and instructional resources rise (nearly) monotonically with income. That is, students not only switch from no-college to four-year college as income rises but they also "upgrade" from two- to four-year college and from colleges with fewer resources to colleges with more resources. Third, grants and scholarships first fall with income (as need-based aid falls), then rise in income (reflecting the fact that upper-middle income students attend more expensive schools and are more likely to receive merit aid), and then fall in income again (because affluent households receive little aid of any kind). Fourth, student loan interest rises and then falls with income. Low-income households receive more generous need-based grants and have little borrowing capacity. Thus, loans peak for households in the $\$ 90,000$ to $\$ 110,000$ range and thereafter fall, presumably because more affluent households do not need to borrow much to finance college education.

\section{Income Dynamics}

The DTF income thresholds have remained the same in nominal dollars but the incomes of households in the vicinity of the eligibility cutoffs tended to grow, in nominal terms at least, over the years we study. Therefore, if a household with a prospective college student gets near an income cut-off, it typically crosses as its income rises. These income dynamics are relevant to regression discontinuity analysis because a household that is close to but below a threshold (eligible, in other words) in year 0 is fairly likely to cross that threshold sometime before year 4 .

To see this, consider income dynamics for the 2002 cohort's households whose MAGI was $\$ 0$ to $\$ 10,000$ below $\$ 120,000$ in the year they should have graduated from high school. We deliberately examine this "placebo threshold" rather than an actual DTF threshold because we are interested in income dynamics that are unaffected by income management.

We find that households who had MAGI $\$ 0$ to $\$ 10,000$ below the placebo threshold in year 0 had a 42 percent probability of being (placebo) eligible in that year only. The households had a 21 percent probability of being eligible in years 0 and 1, a 10 percent probability of being eligible in years 0 through 2 , and a 27 percent probability of being eligible for all four years from 0 to 3 . Over years 0 through 3 , only 6 percent of households cross the placebo threshold first in an upwards and later in a downwards direction.

In short, a student who is near a DTF threshold but treated in his freshman year (the 0-1 school year) has a high probability of being treated in his sophomore year (the 1-2 school year), a good chance of being treated in his junior year (the 2-3 school year), but only a small chance of being treated in his senior year (the 3-4 school year). It will be useful to remember these dynamics when interpreting the regression discontinuity results.

\section{The Regression Discontinuity Method}

Our regression discontinuity analysis is based on the assumption that other factors that affect 
college-going change continuously through the income eligibility thresholds while, as already shown, the DTF changes very discontinuously. Following the standard formulation (Hahn, Todd, and van der Klaauw, 2001), we specify that the causal effect of the DTF on college outcome $Y$ can be expressed by the following equation, where $d$ is the distance between MAGI and the eligibility cutoff.

$$
\lim _{d \downarrow c} E[Y \mid d]-\lim _{d \dagger c} E[Y \mid d]=\beta+\lim _{d \downarrow c} E[\varepsilon \mid d]-\lim _{d \dagger c} E[\varepsilon \mid d]
$$

If other factors that affect college outcomes, å, do not change discontinuously at the cutoff:

$$
\lim _{d \mid c} E[\varepsilon \mid d]-\lim _{d 1 c} E[\varepsilon \mid d]=0
$$

then $\beta$, the change in the college outcome at the eligibility threshold, is the causal effect of the DTF. This implies the standard estimating equation:

$$
Y_{i h}=f\left(d_{h}\right)+\beta \cdot \text { Eligible }_{h}+\varepsilon_{i h}
$$

where $i$ indexes potential students, $h$ indexes tax filing households, $f$ is a continuous function such as a polynomial, and Eligible is a indicator for the household being eligible for the DTF on the basis of its MAGI. There are no time subscripts in the equation yet. This is an issue we discuss below.

We follow the recommended procedure (Lee and Lemieux 2010) and estimate results for alternative polynomials in distance and alternative bandwidths that encompass the optimal bandwidth ranges (Imbens and Kalyanaraman, 2012).

\section{The Suitability of the Tax Deduction for Regression Discontinuity Analysis}

Regression discontinuity methods work best in an environment where (i) a threshold in a continuous forcing variable (income) generates a large change in a policy variable (the amount of DTF for which a student qualifies); (ii) the threshold is strictly enforced; (iii) there are very dense data near the threshold for the forcing, policy, and outcome variables; (iv) other factors that might affect college-going do not change discontinuously at the threshold; (v) people do not manipulate the forcing variable near the threshold in an attempt to make themselves eligible.

Below, we show that our setting easily satisfies conditions (i) through (iv). Now, however, we focus attention on condition (v) because it is crucial for what follows.

A. Income Management

To analyze the DTF using regression discontinuity, we need the forcing variable, MAGI, to be free of manipulation or "management" near the threshold. While such management may be perfectly legal, it can generate serious reverse causality bias because the only people who have an incentive to manage MAGI are those who pay tuition and fees during the tax year. Thus, 100 percent of "managers" who end up just below the cutoff have a student attending college while only a share of "non-managers" who remain above the cut-off have a student in college. For managing households, the DTF does not cause college attendance. Rather, the reverse is true: college attendance causes households to practice income management so that they can take the DTF. This reverse causality means that if we do not fully eliminate the effects of income 
management, our estimates will be biased in favor of finding that the DTF raises college-going.

Some forms of income management require the household to foresee that it will be above the cutoff in the absence of management. For instance, if a household decides to delay the receipt of some income, it must do this before December 31st. On the other hand, a household can deposit money in an IRA right up until April 15 of, say, 2004 and still have that deposit reduce its 2003 MAGI. Thus, a household that does not realize that it is above the cutoff for the DTF until it actually files its taxes could manage its income at late as the day on which it files so long it has not already exhausted its annual IRA contribution limit. Most forms of illegal evasion, such as overreporting business or moving expenses, could also occur as late as tax filing day. Of course, all forms of income management impose some implicit or explicit costs on the household. The greater the DTF that a household would receive if eligible (that is, the greater the tuition and fees it paid), the greater its incentive to manage income.

The test for management of the forcing variable is whether there is displacement of the MAGI distribution from above to below the eligibility cutoff. We show such tests in Figure 1 and Appendix Figures 1 through 5 using income bins that are \$500 wide. (We show year 1 because it is the year in which people are most likely to be enrolled in higher education. Similar figures for years $0,2,3$, and 4 may be obtained from the authors.)

It is visually obvious that households manage their incomes to make themselves eligible for the DTF if they would otherwise be just above the cut-off. For instance, in Figure 1 (joint filers in 2002 and 2003 near the $\$ 130,000$ cutoff), mass is missing from the bins between $\$ 130,001$ to $\$ 133,000$. Mass is added to the added to the 127,001 to $\$ 130,000$ bins. The parallel Appendix Figures 1 and 2 (for 2004 through 2008) show similar displacement within $\$ 3,000$ on each side of the cut-off.

For single filers at all three thresholds (Appendix Figures 3 through 5), there is evidence of income management but only for the bins that are within $\$ 1,500$ on each side of the cut-off. Of course, given single filers' lower incomes, a $\$ 1,500$ change in income is as consequential in percentage terms as a $\$ 3,000$ change for joint filers.

If we do not exclude the data in the region subject to income management, we will overestimate the effects of the DTF on college enrollment, the amount spent on tuition and fees, and the college resources that students experience. To avoid this reverse causality-induced bias, we must impose a doughnut-hole around each cut-off so that our estimates do not rely on the households most likely to practice income management. Currently, there is no econometric theory of optimal doughnut-holes (although one of the authors is working on this problem with an econometrician). However, the basic logic is as follows. We want to impose a doughnut-hole that is sufficiently wide to eliminate reverse causality bias. The wider the doughnut-hole, though, the more reduced is our statistical power. This is because, as we widen the doughnuthole, we cannot widen the bandwidth unthinkingly. The plausibility of our model of the continuous relationship between income and college-going deteriorates as we draw observations further from the threshold. This is fundamental to the logic of regression discontinuity identification.

To choose a doughnut-hole that is sufficiently wide to eliminate bias from income management but not so wide as to eliminate statistical power, we proceed as follows. We estimate the bias in each small income range by running a local regression of density $(g)$ on 
MAGI--omitting $\$ 5,000$ on either side of each cut-off. ${ }^{14}$ This gives us a prediction of what density would be in the absence of income management. Thus, we also have an estimate of the excess or missing density at each MAGI. We then take the base rate of college-going around each threshold from Table 1. (For instance, the base rate of college attendance is 80 percent for individuals from joint filing households near the $\$ 130,000$ threshold. ) We assume that all of the excess and missing density is associated with individuals who have a 100 percent probability of attending college since only they have an incentive to practice income management.

Then, for each possible doughnut-hole and each outcome, we have estimates of the bias due to income management and of the standard error of the effect of DTF eligibility. If the bias is such that it would be statistically significantly different from zero, a larger doughnut-hole is needed.

For instance, using the $\$ 130,000$ threshold for the 2002 and 2003 cohorts, the estimated effect of the DTF on college attendance would be upward biased by 2.4 percentage points (0.024) with no doughnut-hole. Since the standard error is as small as 0.003 (with a quartic polynomial and $\$ 20,000$ bandwidth), this bias would be highly statistically significant and misleading. With a $\$ 1,000$ doughnut-hole, the bias is 1.6 percentage points $(0.016)$ and the standard error is as small as 0.004 so we would again have the appearance of a statistically significant effect where there is none. With a $\$ 2,000$ doughnut-hole, the estimated bias is 1.3 percentage points and the standard error is between 0.007 and 0.018 depending on the polynomial and bandwidth. Thus, the bias would be statistically significantly different from zero in some cases. With a $\$ 3,000$ doughnut-hole, we estimate the bias to be 1 percentage point and, in all cases, the standard errors are such that this bias would not be statistically significantly different from zero. This suggests that we need a $\$ 3,000$ doughnut-hole at this threshold.

We estimate that we need $\$ 3,000$ doughnut-holes for all the joint filing thresholds and $\$ 1,500$ doughnut-holes for the single filing thresholds. It is reasonable that larger doughnutholes in absolute dollars are needed for joint filers' thresholds because the doughnut-holes they need are about the same percentage of income as the single filers'. For the remainder of the paper, we call the doughnut-hole we need the "base case" and use bold type face to emphasize the base case estimates in tables where we show results for a variety of doughnut-holes. (We could show estimates only for the base case since we think that only those estimates are free of bias. However, by showing estimates for a variety of doughnut-holes, we allow readers to gauge the extent of reverse causality bias caused by income management.) Doughnut-holes larger than the base case needlessly reduce statistical power.

Recall that MAGI is equal to total income minus the other above-the-line deductions. We therefore investigated the channels through which income management occurs. We found no evidence that other deductions, such as the IRA deduction, jump discontinuously at the MAGI threshold. This suggests that other deductions are not the primary channel for income management. However, deductions vary so greatly that they might matter a lot and still not generate compelling evidence. On the other hand, we observe displacement in total income that is similar to what we observe in MAGI. In addition, we observe that income management appears to be non-existent among households that report only wage and salary income. ${ }^{15}$ Thus,

\footnotetext{
${ }^{14}$ In practice, a local regression with a quadratic in MAGI has very high explanatory power.

15 The evidence mentioned in this paragraph is available from the authors.
} 
we conclude that most of the income management visible in Figure 1 and Appendix Figures 1 through 5 operates through channels such as schedule $\mathrm{C}$ business income, capital gains, rental income, partnership income, $\mathrm{S}$ corporation income, farm income, and the like.

\section{B. Changes in Aid at the Income Eligibility Thresholds}

Figures 2 and 3 and Appendix Figures 6 through 10 show that the income eligibility thresholds for the DTF are strictly enforced and that the deductions fall by large amounts at the threshold. All the figures use year 1 data, employ $\$ 500$ wide MAGI bins, and show kernel-weighted local polynomial regressions. The local polynomial regressions are shown in two ways: (i) using all of the observations, (ii) using all the observations except those in the base case doughnut-hole around the threshold. The figures are mirrored by Tables 2 and 3 which show regression discontinuity estimates of the effect of income eligibility on, respectively, DTF take up and the deduction amount (unconditional on take up). To aid interpretation, the final line of Table 3 shows the average deduction amount taken by households at each income eligibility threshold conditional on taking the DTF. Appendix Tables 3 and 4 are extended versions of Tables 2 and 3: they show results for a wider variety of bandwidths and polynomials.

Figures 2 and 3 show, that for the 2002 and 2003 cohorts, the share of joint filers who took the DTF in year 1 is 58 percent with the base case doughnut-hole. The average DTF is $\$ 1,573$ at the threshold which means that households near the threshold who were taking it were taking a deduction of $\$ 2,646$, close to the maximum allowable DTF of $\$ 3,000$ in 2002 and 2003.

Appendix Figure 6 and Tables 2 and 3 tell a similar story for the 2004 through 2008 cohorts. Joint filers' take-up of the top tier DTF rate drops by 55 percent at the lower cut-off if we use the base case doughnut-hole. The average deduction drops by $\$ 1,023$ at the lower cut-off in the base case. This means that households just below the threshold who were taking the DTF were taking a deduction $\$ 1,498$ larger than that of households just above the lower cut-off.

Appendix Figure 7 and the fourth column of Tables 2 and 3 show the upper cut-off among 2004 through 2008 cohorts who file jointly. Their take-up rate falls by 64 percent with the base year doughnut-hole. The average deduction drops by $\$ 1,199$ at the upper cut-off in the base case. This means that households just below the upper cut-off who were taking the DTF were taking a deduction of $\$ 1,860$, close to the maximum of $\$ 2,000$.

Appendix Figures 8 through 10 and the remaining columns of Tables 2 and 3, for single filers, also exhibit sharp discontinuities in the receipt of aid at the cut-offs and income management in the immediate vicinity of the cut-offs. Focusing on year 1 and our base case doughnut-holes for single filers, we estimate that 24 percent of those in the 2002 and 2003 cohorts who were just below the cut-off took the DTF and their average deduction--conditional on taking a deduction--was $\$ 2,279$. For the 2004 through 2008 cohorts, single filers' take-up of the top tier DTF fell by 19 percent at the $\$ 65,000$ cut-off and their average deduction-conditional on taking a deduction--fell by $\$ 1,178$ there. Their take-up rate fell by 30 percent at the $\$ 80,000$ cut-off and their average deduction--conditional on taking one--was by $\$ 1,755$, the maximum being $\$ 2,000$.

It is notable that single filers are less likely to take the DTF and take slightly lower deductions, when they take one, than joint filers. This is mainly because students from single filing households tend to attend less expensive schools.

C. Summing Up the Usefulness of the "Experiments"

So far, we have focused on the year 1 effects of the income thresholds with the base case doughnut-hole, a quintic polynomial, and a bandwidth of $\$ 20,000$ for joint filers and $\$ 10,000$ for 
single filers. (Because they are about the same share of income at the income at the threshold, the base case has a $\$ 20,000$ bandwidth for the joint filers and a \$10,000 bandwidth for single filers.) We show this case in bold in the top row of Tables 2 and 3. We use the other rows of the tables and Appendix Tables 3 and 4 to demonstrate a few other points. First, the estimated effects of income eligibility are sensitive to the width of the doughnut-hole. The effects with a zero doughnut-hole are very often statistically significantly larger than the effects with the base case doughnut-holes. This is evidence of income management. Second, although wider bandwidths substantially reduce our standard errors, they do not much change the estimated effects of income eligibility on take-up or the deduction amount. This is not a surprise because it is visually obvious in Figure 1 and Appendix Figures 1 through 5: The relationships between the DTF variables and MAGI tend to be flat near the income cut-offs so bandwidth is unimportant. Third, the estimated effects of eligibility on take-up and the deduction amount do not depend much on the order of the polynomial that we use. This suggests that, apart from income management and the rule-driven discontinuity, the MAGI-deduction relationship is smooth enough to be modeled well with a quintic polynomial. We do not need a higher order one.

In short, the doughnut-holes matter. The order of the polynomial and the bandwidth are less important.

Table 4 shows the effects of the income thresholds on take-up and the amount of the DTF for all of years 0 through 4 . For conciseness, they show only the base case. The effects are always greatest in year 1. This is to be expected since year 1 picks up the school years in which people are most likely to enroll in postsecondary education. The effects rise from year 0 to year 1 and then fall away gradually from year 1 to year 2, year 3, and year 4 . In other words, the DTF is most relevant in the years in which people are most likely to attend college.

We take away a few conclusions. First, all of the estimated effects on DTF take-up are highly statistically significant. For the base case, the t-statistics for the effect of the DTF threshold on take-up range from 43 to 80 for joint filers and range from 13 to 25 for single filers. (Recall that there are fewer single filers near the thresholds than joint filers.) Thus, we do not lack statistically strong "experiments." Second, the amount of the deduction taken by those who are just short of an income cut-off is consistently between 75 and 93 percent of the maximum allowable ( $\$ 2,000$ to $\$ 4,000$ depending on the cut-off) for joint filers and 59 to 88 percent for single filers. Thus, the changes in aid experienced at the thresholds are substantial. Third, the estimated effects are insensitive to the polynomial and bandwidth but sensitive to the width of the doughnut-hole. Thus, we will only obtain plausibly causal effects of the DTF on collegegoing if we apply the base case doughnut-holes.

\section{Anticipation and Salience: Price versus Income Effects}

The timing of DTF filing and receipt affect how we implement the regression discontinuity method and interpret its results. Consider four cases: (i) households who always understand the DTF rules; (ii) households who are not aware of the DTF rules until they find themselves eligible for it but who thereafter understand the rules; (iii) households who never understand the DTF rules and simply accept the extra income as an exogenous "helicopter drop;" (iv) households who never understand the DTF rules but expect to be eligible in this tax year if they were eligible in the last tax year.

We are mainly concerned with what these cases imply for our analysis. However, the discussion also has substantial behavioral economics interest. How families actually think about 
the DTF matters. It is not enough to know what a rational economist trained in tax rules would think.

Among relevant households who understand the DTF rules, 2003 eligibility matters for 2003 college decisions, 2004 eligibility for 2004 decisions, and so on. Thus, the regression discontinuity should be set up with year $t$ choices as the dependent variables and year $t$ eligibility and distance from the cutoff as the independent variables:

$$
Y_{i h t}=f\left(d_{h t}\right)+\beta \cdot \text { Eligible }_{h t}+\varepsilon_{i h t}
$$

where â should be interpreted as the effect of a change in the price of college equal to the certainty equivalent of the DTF.

If households are initially ignorant of the DTF rules but learn them once they take the DTF, they will fail to respond in their first year of eligibility but, after that, start behaving like always-knowledgeable households. Thus, the appropriate regression discontinuity equation is the same. However, we expect â to be greater if a household has DTF experience.

If households never learn the DTF rules but simply find themselves with extra income, they will experience a pure income effect in the tax year after they are eligible. The appropriate regression discontinuity specification has the previous year's distance and eligibility as the independent variables:

$$
Y_{i h t}=g\left(d_{h, t-1}\right)+\gamma \cdot \text { Eligible }_{h, t-1}+\varepsilon_{i h t}
$$

and ã represents the pure income effect of the DTF. This income effect is likely to be very small because it is logically bounded by the income-college relationships shown in Table 1 . The statistics shown in the table are almost surely upward biased indicators of the causal effect of income on college-going because wealth, parents' education, and other factors that increase college are positively correlated with income and are not controlled in the table. For instance, near the $\$ 130,000$ joint filing threshold, a $\$ 3,000$ DTF that increases a household's income by about $\$ 1,000(\$ 3,000 \mathrm{DTF}$ with a 28 percent marginal tax rate) could have at most a 0.14 percentage point effect on college attendance and a 0.18 percentage point effect on 4-year college attendance (conditional on attending). ${ }^{16}$ These numbers are crucial for understanding our results: the DTF's causal effect on college-going must necessarily be tiny if it runs through an income effect rather than a price effect.

Finally, if households never learn the rules but expect to remain eligible once they have received the DTF, the DTF should act like a change in the price of college in the year after the household is eligible. Thus, the appropriate regression discontinuity specification is same as in the previous case but ã now represents the effect of a perceived (not necessarily actual) change in the price of college.

Since households may be of all the types described above, we first estimate the all-in-thesame-tax-year regression (equation 4) with a doughnut-hole:

\footnotetext{
${ }^{16}$ To see this, observe the statistics in Table 1a on either side of the $\$ 130,000$ threshold. Then observe that (80.8\% $79.4 \%) / 10=0.14 \%$ and that $(72 \%-70.2 \%) / 10=0.18 \%$.
} 


$$
Y_{i h}=f\left(d_{h t}\right)+\beta \cdot \text { Eligible }_{h t}+\varepsilon_{i h t}
$$

$$
\left\{h: r<d_{h t}<b\right\}
$$

where $r$ is the radius of the doughnut-hole (for instance, $\$ 3,000$ on either side of the cut-off) and $b$ is the bandwidth (for instance, $\$ 20,000$ on either side of the cut-off). We then estimate a regression that allows the previous year's eligibility to matter:

$$
Y_{i h t}=f\left(d_{h t}\right)+g\left(d_{h, t-1}\right)+\alpha \cdot \text { Eligible }_{h t}+\gamma \cdot \text { Eligible }_{h, t-1}+\varepsilon_{i h t}
$$

where $g$ is a polynomial in the previous tax year's MAGI distance from the cutoff. We estimate this equation using only the data within the bandwidth but outside the doughnut-hole in both years $t$ and $t-1$ :

$$
\left\{h: r<d_{h t}<b \wedge r<d_{h, t-1}<b\right\}
$$

We impose a doughnut-hole on both years because we do not know which type each household is, and this is thus the only way to exclude bias due to income management.

\section{The Effects of the Deduction for Tuition and Fees}

A. Differentiating Visually between Causal Effects and Income Management

Before examining figures based on actual data, it is useful to illustrate how one would differentiate visually between a causal effect of the DTF and income management. Figure 4 shows what a causal effect of the DTF on college attendance would look like in its left panel. Its right panel shows what income management would look like.

At the eligibility threshold, a household's potential DTF falls and this may exert a price, income, or liquidity effect that causes a downward shift in the level of attendance. Crucially, this shift should affect a wide array of households above the cut-off, not merely households in the doughnut-hole. Thus, we obtain a picture like that shown in the left panel, where the income-attendance relationship exhibits a vertical shift downwards at the threshold but otherwise maintains its shape.

In contrast, income management would produce an upward "flick" of the incomeattendance relationship just before the threshold and a downward flick just after the threshold. The flicks would be contained in the doughnut-hole. These flicks are the symptom of households who would contain a college student in any case managing their incomes to gain DTF eligibility. Apart from these flicks (and outside the doughnut hole), the income-attendance relationship would appear as though the threshold did not exist.

Of course, a figure might show evidence of both a causal effect (the downwards shift) and income management (the flicks).

B. The Current Year Effects of the Deduction for Tuition and Fees In this subsection, we focus on year 1 and the all-in-the-same-tax-year specification (6). That is, we focus on the specification that assumes families understand the DTF well enough for it to exert a price effect. Since we are examining year 1 effects, about half of the families eligible for the DTF will have been eligible in the previous year (year 0). Thus, even if families have to experience the DTF in a previous year to understand it as a price effect, we may find evidence of 
all-in-the-same-tax-year effects.

Figures 5 through 8, Appendix Figures 11 through 14, and Tables 5 and 6 present the effects of the DTF on attending postsecondary school (at all) and on attending four-year college (conditional on attending). Our definition of postsecondary attendance (at all) is whether a person is a student for whom "qualified" tuition and fees were paid or billed. That is, our definition is aligned with the DTF rules. As in the previous figures, we employ $\$ 500$ MAGI bins and show kernel-weighted local polynomial regressions using (i) all of the observations, (ii) the observations except those in the base case doughnut-holes. We show other outcomes, years, and specifications in subsequent tables.

The figures provide no visual evidence that the DTF affects either attendance or fouryear college. On the other hand, the figures do provide clear visual evidence of income management. The flicks are small but visible especially in the four-year figures for married filers. For instance, Figures 6 and 8 make it obvious that households with students attending four-year college manage their incomes to get just below the income threshold. The visual evidence indicates that these managing households would have had incomes above the threshold but within $\$ 3,000$ of it. It is harder to see the flicks in the figures for single filers because all effects are smaller for them, but close inspection suggests that they manage income too.

Of course, visual evidence is not precise so we now turn to regression estimates. The top row of Table 5 shows the effects of the DTF on attendance in our base case. Without exception, the estimated effects are not statistically significantly different from zero. The standard errors are such that we cannot rule out very small effects such as a 1 percentage point effect. However, we can rule out effects of 2 percentage points.

Indeed, examining all the rows of Table 5 and Appendix Table 5 (which is an extended version that shows a wider array of bandwidths and polynomials), we see a consistent story. If we ignore income management and set the doughnut-hole to $\$ 0$, the DTF apparently raises attendance and four-year college. However, this apparent effect is certainly reverse causality bias because it disappears as the doughnut-hole increases from $\$ 0$ (implausible) to the base case that eliminates the effects of income management. Any apparent effect is pure bias.

Although the estimates are sensitive to the width of the doughnut-hole, they are not notably sensitive to the polynomial or bandwidth. This is not surprising because, as shown in the figures, the relationships are quite smooth apart from the flicks in the doughnut-holes. In estimates not shown but available, we find that increasing the bandwidth merely generates more precisely estimated null effects.

Table 6 repeats the exercise for four-year college attendance, conditional on attending at all. For the base case (top row), the estimated effects of the DTF on four-year college are never statistically significantly different from zero. The standard errors are such that we cannot rule out small effects of about 2 percentage points for joint filers. The remaining rows of Table 6 and Appendix Table 6 (which shows more specifications) tell a consistent story: Income management generates estimates that are substantially upward biased if we apply a $\$ 0$ doughnuthole. Thus, a naive analysis might suggest that the DTF has a causal effect on college-going. This suggestion disappears when we apply doughnut-holes that plausibly eliminate reverse causality bias.

Table 7 shows the base case regression discontinuity results for years 0 through 4 for joint and single filers. Broadly, these confirm the year 1 results: A few estimates suggest that the DTF has a statistically significant causal effect on attending (at all), but the ratio of 
statistically significant estimates to all estimates is about what we would expect to occur if the true effect were zero given 90 and 95 percent confidence intervals. There are no estimates that suggest that the DTF causes students to attend four-year college (conditional on attending).

Table 8 shows the base case regression discontinuity effects of DTF eligibility on further college-related outcomes. There is little or no evidence that the DTF has a statistically significant causal effect on attending full-time (conditional on attending), on two-year college (conditional on attending), the instructional spending of the college attended, the core studentrelated expenditure of the college attended (an indicator of the school's resources), the "sticker price" tuition of the college attended (an indicator of how expensive it is for a full-pay student), the tuition actually paid (net of grant aid), or grants and scholarships received.

Interestingly, the DTF also does not statistically significantly affect the interest paid on student loans in years 1 through 7. (For instance, we sum interest paid in 2003 through 2009 for the 2002 cohort.) This lack of an effect on interest paid suggests that when families receive the DTF, it does not reduce their student debt. Of course, the DTF unambiguously increases the family's income so it must increase consumption, increase saving, or reduce debt other than student loans (credit card debt, for instance).

C. Effects of Taking the Deduction for Tuition and Fees in the Current and Previous Year We found no evidence that the DTF affects college-going outcomes in the year in which it is taken. There are several possible explanations, some of which we consider only in the next section. Here, however, let us consider whether families who receive the DTF in year $t-1$ act as though they qualify for a discounted price of college in year $t$--even though this is not the way the DTF works. If this is so, estimates of equation (7) should show them reacting to lagged DTF eligibility.

Because it requires a household's income to have been in the vicinity of a DTF threshold in two subsequent years, we have fewer observations to estimate the lagged specification given by (7). Therefore, we focus on a $\$ 20,000$ bandwidth even for single filers. We also focus on the $\$ 65,000$ single and $\$ 130,000$ joint thresholds because, by combining all available years across the two DTF regimes, we can include four cohorts: 2002, 2003, 2004, 2007. ${ }^{17}$ Finally, we focus on years 0,1 , and 2 in which people are most likely to attend college. (Results available from the authors show similar effects for years 3 and 4.

Table 9 provides no indication that lagged or current eligibility for the DTF affects college attendance (at all), attending full-time (conditional on attending), attending four-year college (conditional on attending), attending two-year college (conditional on attending), the instructional spending of the college attended, the core student-related expenditure of the college attended, the sticker price of the college attended, the tuition actually paid, grants and scholarships received, or the interest paid on student loans in years 1 through 7 . None of the estimated effects is statistically significantly different from zero. However, because the standard errors are larger with the lagged specification, the effects that we cannot rule out are slightly larger. For instance, we cannot rule out attendance effects of 2 percentage points for joint filers or 3 percentage points for single filers.

\footnotetext{
17 Recall that there was no DTF in the 2006 tax year. Thus, both the 2005 and 2006 cohorts must be omitted from the specification (7) with lagged eligibility. Estimates for the $\$ 80,000$ and $\$ 160,000$ thresholds can employ only the 2004 and 2007 cohorts. As a result, those estimates, while similar, have standard errors that are larger than desirable. These results are available from the authors.
} 


\section{Discussion}

\section{A. Our Findings, Summarized}

After testing a broad array of possibly affected outcomes using a method, regression discontinuity, that imposes minimal assumptions, we find no evidence that the DTF affects college-going. This conclusion is robust to choices about the polynomial and bandwidth used for the regression discontinuity specification.

We find that the DTF is taken up by a substantial share of households and that they take deductions close to the maximum allowed. They accurately apply the DTF rules to the MAGI they report to the Internal Revenue Service. As a result, many households that are paying tuition and fees $d o$ have higher net-of-tax incomes as a result of the DTF. They are spending or saving this income in some way, but it is evidently some way that does not affect college-going more than negligibly.

We find that households near the income eligibility cut-off for the DTF manage their MAGI so as to push it slightly below the cut-off. This income management need not be illegal evasion: Various legal forms of avoidance could generate the same result. Moreover, although income management is a nuisance for implementation of the regression discontinuity method, its implications for tax revenue and tax fairness are small. Most of the households who are practicing income management would have MAGI just above the cut-off report MAGI just below the cut-off. Put another way, the reason that we exercise considerable vigilance about income management--by imposing doughnut-holes--is that we wish to avoid producing estimates that suffer from reverse causality bias. If we were not concerned with producing causal estimates and were only concerned about lost tax revenue, such vigilance would make little difference.

B. What Explains the Tax Deduction's Lack of Effect on College-Going? One explanation for the DTF's lack of effect on college-going is that households in the vicinity of the income cut-offs may be insensitive to the price of postsecondary education. That is, the elasticity of their college-going behaviors with respect to the price may be so low that it is indistinguishable from zero. This explanation is not implausible because families near the cutoffs are fairly affluent and may therefore be insensitive to prices. ${ }^{18}$ Moreover, the vast majority of the cost of college for most students is the opportunity cost, not tuition and fees. Perhaps we would not be surprised if we learned that a $\$ 1,000$ decrease in the opportunity cost of college produced a negligible change in college-going among people from households near the income cut-offs. If so, we should also not be surprised to learn that a DTF worth $\$ 1,000$ produced a negligible change in college-going among people from the same households.

However, it is possible that these households are sensitive to the price of college but that the DTF is structured in a way that makes it inefficacious. This possibility is especially interesting because the DTF's structure could be altered, without changing its potential cost, to make it more likely to achieve its intended, causal effects.

To see this, consider four interrelated aspects of the DTF that may make it inefficacious: the lack of salience of the DTF rules, the timing with which households become aware of the deduction for which they are eligible, the timing with which the deduction is received, and

\footnotetext{
18 Table 1 indicates that the eligibility cut-off occurs at the 82th percentile of income among joint filers with a 17 year-old in year -1 and the 89 th percentile among single filers with a 17 year-old in year -1 .
} 
aspects of the DTF that make it likely to be perceived as additional income rather than a change in the price of college.

As noted earlier, the DTF rules are not obvious. This likely lack of salience matters because of the DTF's timing. Consider the time line for a typical prospective student who applies to college for the first time. In the third quarter of year $t-1$ or early in the first quarter of year $t$, she applies to colleges. Also in the first quarter of year $t$, she completes the Free Application for Federal Student Aid. In April of year $t$, she learns which schools have admitted her and what financial aid packages she has been offered. In May of year $t$, she accepts an admissions offer. This is also when she makes decisions about whether to take out loans and/or accept a work-study job. Some schools require a deposit on tuition and fees at this time. In August or September of year $t$, she pays tuition and fees for the fall term. In December of year $t$ or in the first quarter of $t+1$, she pays tuition and fees for the spring term(s). Finally, by April 15 of year $t+1$, she or--more likely--her parents file their taxes. When they do so, they realize the deduction or, at a minimum, learn its income implications.

In short, the prospective student makes all of her college-going decisions--where to apply, which college to accept, which financial aid package to take, what loans to assume--10 to 18 months before the deduction is realized. Thus, if she fails to predict the DTF well in advance, her decisions may be unaffected or affected in some way that produces a negligible causal effect.

Moreover, even if the student is expert at predicting the DTF, she or her parents may be liquidity constrained at the times when tuition and fees are due. Since the deduction will not have been realized at those times, the DTF will not relax such liquidity constraints. ${ }^{19}$ Its future receipt will not affect college choices. Thus, even a household that fully understands the DTF may act as though it did not exist.

Finally, the DTF seems designed to convince families that it is an increase in parents' income rather than a decrease in the price of the student's college. It is computed on separate forms (or in a series of rule-obscuring frames if a tax preparer or software is used), transferred to one of a series of deduction lines on form 1040, eventually multiplied by the household's tax rate, and ends up reducing the taxes paid by the filer, who is usually not the student. A family might make all of the connections and recognize that the DTF is actually a discount on the price of college, not an increase in net-of-tax income. However, it is doubtful whether the ordinary family is so savvy. We have already seen that if the family perceives the DTF to be a change in income rather than price, the effect on college-going is likely to be negligible.

C. The Tax Credits' Analogous Issues and Lack of Effect on College-Going In previous work (Bulman and Hoxby 2015), we demonstrate that the tax credits for higher education--which cost as much as $\$ 25$ billion a year--also have little or no effect on collegegoing. Moreover, some estimates in that work are "local" to households with modest incomes: married joint filers with $\$ 25,000$ to $\$ 50,000$, for instance. The tax credits appear not to affect their college-going, but it seems implausible that such households are simply too affluent to be sensitive to the price of college.

While the credits differ substantially from the DTF, the credits share the features likely to make the DTF inefficacious: a lack of salience, timing unaligned with decision-making and

\footnotetext{
${ }^{19}$ In theory, a household that accurately predicts its receipt of a DTF could petition its employer(s) to reduce its
} withholding, thereby realizing the DTF before it files. However, such changes in withholding are extremely rare. 
tuition bills, a method of receipt that makes them likely to be perceived as income rather than as a change in the price of college.

If it is their shared features that make the credits and DTF inefficacious, we should not be surprised that both programs, despite their differences, have little or no effect on collegegoing.

\section{Simple revisions to the DTF might increase its causal effects}

To illustrate the point that relatively arbitrary features of the DTF may explain its inefficacy, we propose a simple experiment. Suppose that instead of the DTF being based on tuition and fees and MAGI in year $t$, it were based on tuition and fees in year $t$ (the tax year) and MAGI in the year in which a person was age 17. Suppose also that schools could file to receive the DTF directly from government.

The DTF would work as follows. After a household filed taxes in the year in which its child was age 17, it would receive a notice saying that its child's price of college would be discounted by its tax rate up to a total discount equal to the maximum DTF. This discount might apply in up to a total of four school years out of the next seven. ${ }^{20}$ Thus, a joint filing household with MAGI of $\$ 120,000$ would be notified that its child would receive a 28 percent discount off tuition and fees up to a maximum discount of $\$ 1,120$ (28 percent of $\$ 4,000)$. The household would receive this notice at about the same time of year as it would receive news about the financial aid for which its child would qualify. ${ }^{21}$ Suppose moreover that the household could show this notice to a college when its tuition was due. At that point, the college could collect the discounted tuition and file a claim with the Treasury for the amount of the discount. Since the discount formula would be predetermined, there would be little reason why the Treasury could not send the funds to the college quickly--just as the U.S. Department of Education sends Pell grants to colleges quickly. (Pell grants are also based on current tuition and a predetermined formula.) Households could receive annual reminder notices of their DTF eligibility until the four school years of use or seven school years of eligibility were exhausted, whichever came sooner.

This simple modification would make the DTF much more salient. It would ensure that most people knew about the DTF when making key college-going decisions. The DTF would reduce payments at the time they were due, thereby relaxing liquidity constraints. The DTF would likely be perceived as a change in the price, much as a coupon is perceived. In other words, if the structure of the DTF makes it inefficacious, the modification might make it efficacious. If households fail to respond to the DTF because they are truly insensitive to the price of college, the modification would make no difference.

The modified DTF could be made approximately budget neutral in a prospective sense.

\footnotetext{
${ }^{20}$ Obviously, these constraints could be varied. Because some children progress slowly through elementary and secondary school or take a "gap year" between high school and college, one would not want to constrain people to take their DTF in--say--only four possible school years.

21 This would be true if the child were born in the first three quarters of the year and had progressed in school in an on-time manner. If the child had an fourth quarter birthday and/or had progressed in school with a year's delay, the family would learn of its DTF eligibility one year ahead of its child receiving financial aid information.
} 
That is, the thresholds could be set to make each household eligible for the same expected discount. However, it is unclear why the income of a person's household at age 18 is a better measure of need for college support than the income of a person's household at age 17.

There might be three additional advantages of tax-based aid that used age 17 household income. First, prospective students could plan their college education with a discount that was certain rather one that could disappear under circumstances beyond the student's control. Second, the Treasury and tax preparers could make tax-based aid "forecasters" available to households filing their taxes for the year when their child was age 16. Like the FAFSA4caster, such tools would provide students and their parents with an early estimate of their aid. Third, a measure based on age 17 household income would reduce families' incentives to "game" the dependent/independent classification in an effort to obtain more generous financial aid.

The only clear disadvantage to a DTF based on age 17 household income is that it would give families additional incentive to manage their MAGI so as to get just below the eligibility threshold. (The incentive would be greater because more years of eligibility would be determined at one time.) Such income management could easily be eliminated by making the DTF phase out rather than sharply cut-off at a threshold. There is no evidence that households manage income to obtain the tax credits for higher education which phase out rather than sharply cut off (Bulman and Hoxby 2015).

It would be feasible to test rigorously whether the DTF's and credits' inefficacy is due to their peculiar features or households' insensitivity to the price of college. A randomized controlled trial that varied eligibility and notification in the manner described above (while holding constant all other rules) might elucidate how households interact with the tax expenditures for higher education. Since the DTF and credits potentially support higher education investments with minimal administrative cost, understanding them better might not only clarify household behavior but might be useful for policy.

\section{References}

Bulman, George B. and Caroline M. Hoxby. 2015. "The Returns to the Federal Tax Credits for Higher Education." Tax Policy and the Economy 29: 1-69.

Deming, David and Susan M. Dynarski. 2008. "The Lengthening of Childhood," Journal of Economic Perspectives, 22(3): 71-92.

Davis, Albert J. 2002. "Choice Complexity in Tax Benefits for Higher Education," National Tax Journal, 50 (3): 509-538.

Hahn, Jinyong, Petra Todd, and Wilber van der Klaauw. 2001. "Identification and Estimation of Treatment Effects with a Regression-Discontinuity Design." Econometrica 69(1): 201-209.

Hoxby, Caroline M. 1998. "Tax Incentives for Higher Education." in Poterba, James M. (ed.), Tax Policy and the Economy, Volume 12, 49-82. MIT Press, Cambridge, MA.

Imbens, Guido, and Karthik Kalyanaraman. 2012. "Optimal Bandwidth Choice for the 
Regression Discontinuity Estimator.” The Review of Economic Studies 142: 675-697.

Lee, David S. and Thomas Lemieux. 2010. "Regression Discontinuity Design in Economics." Journal of Economic Literature. 48(2): 281-355.

Long, Bridget Terry. 2004. "The Impact of Federal Tax Credits for Higher Education." in Hoxby, Caroline M. (ed.), College Choices: The Economics of Which College, When College, and How to Pay For It. Chicago, IL: University of Chicago Press, 101-168..

Maag, Elaine, and Jeffrey Rohaly. 2007. "Who Benefits from the Hope and Lifetime Learning Credit?" Tax Policy Center, Urban Institute and Brookings Institution, Washington, DC.

National Center for Education Statistics, Institute for Education Sciences, U.S. Department of Education. Integrated Postsecondary Education Data System. Online data as of August 2015. http://nces.ed.gov/ipeds

Turner, Nicholas. 2011. "The Effect of Tax-based Federal Student Aid on College Enrollment," National Tax Journal 64: 839-861.

U.S. Department of the Treasury, Internal Revenue Service. 2002 to 2014. Form 1040 and Instructions for Form 1040.

U.S. Department of the Treasury, Internal Revenue Service. 2007 to 2014. Form 8917 and Instructions for Form 8917.

U.S. General Accountability Office. 2010. "For-Profit Colleges: Undercover Testing Finds Colleges Encouraged Fraud and Engaged in Deceptive and Questionable Marketing Practices," GAO-10-948T. 
Figure 1

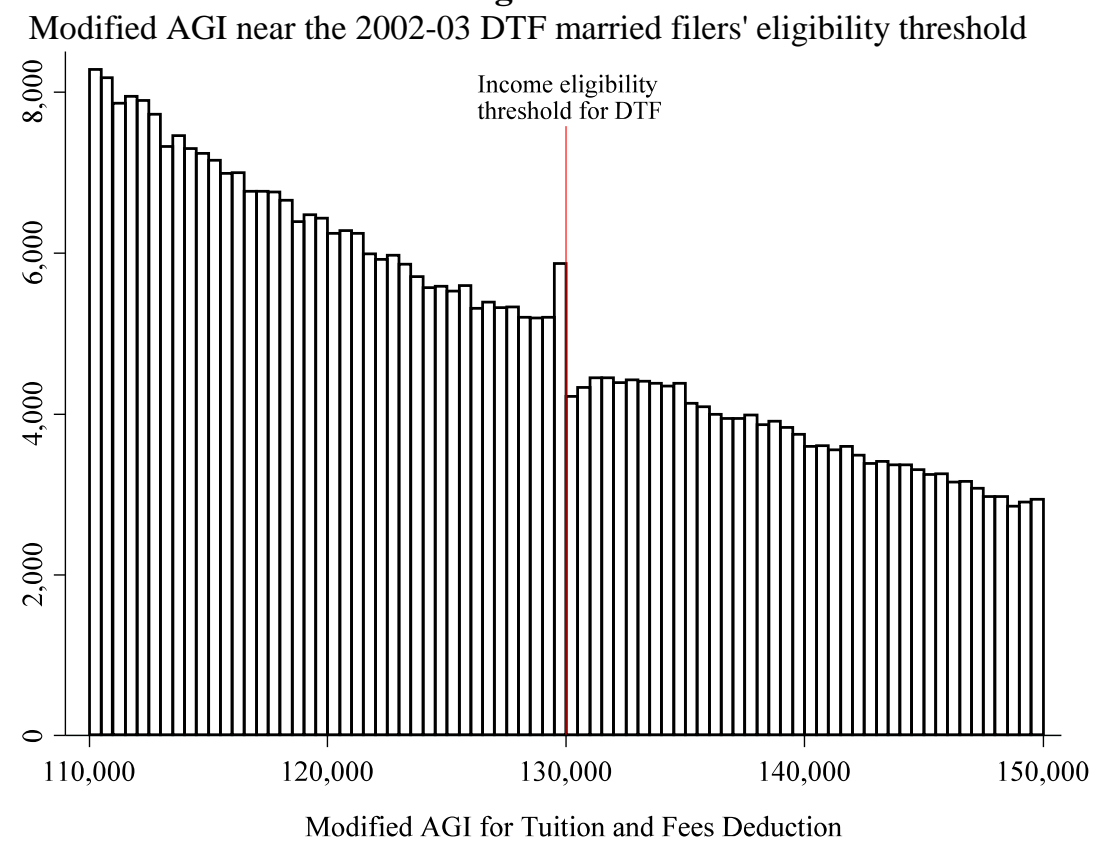

Notes: Figures are histograms of modified adjusted gross income in $\$ 500$ bins in year 1 (2002 and 2003 or 2004 through 2008) among married joint filers who had a child who would have graduated from high school in year 0 if he or she had progressed through secondary school on time. Source: De-identified tax data. 


\section{Figure 2}

Taking the DTF and modified AGI near 2003-04 married eligibility threshold

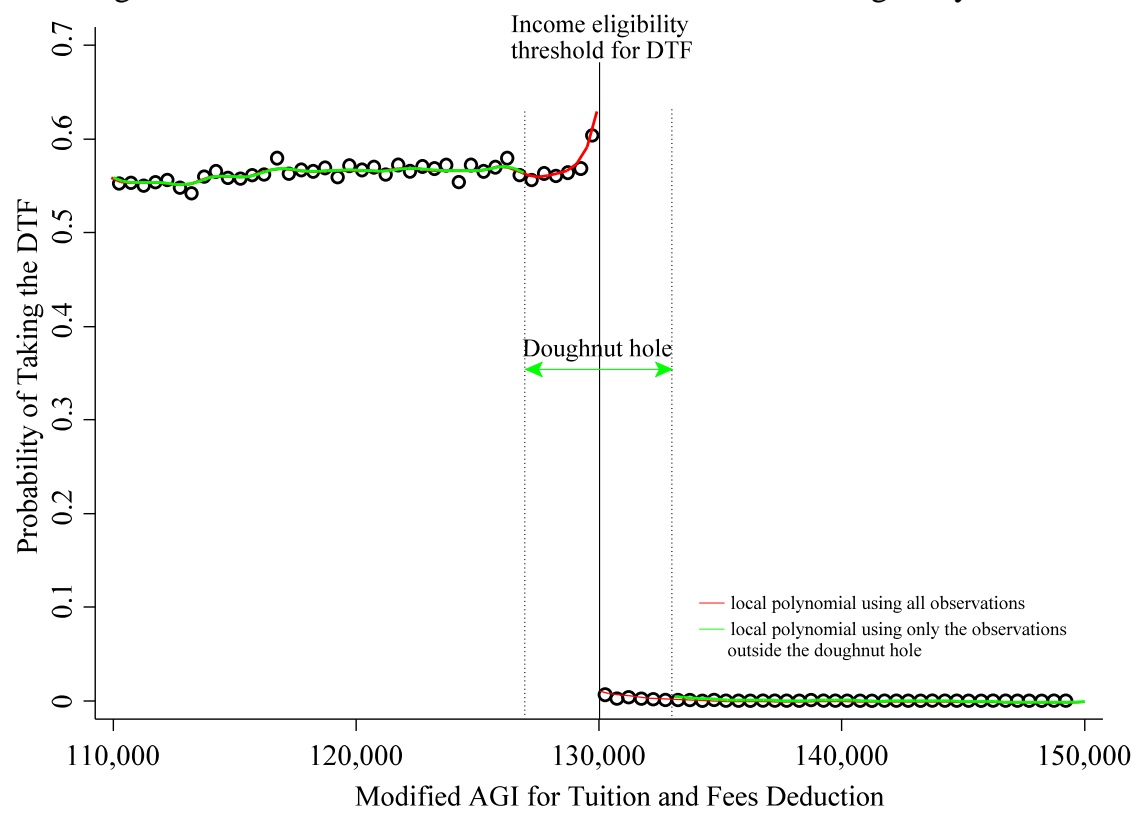

Figure 3

Average DTF and modified AGI near 2003-04 married eligibility threshold

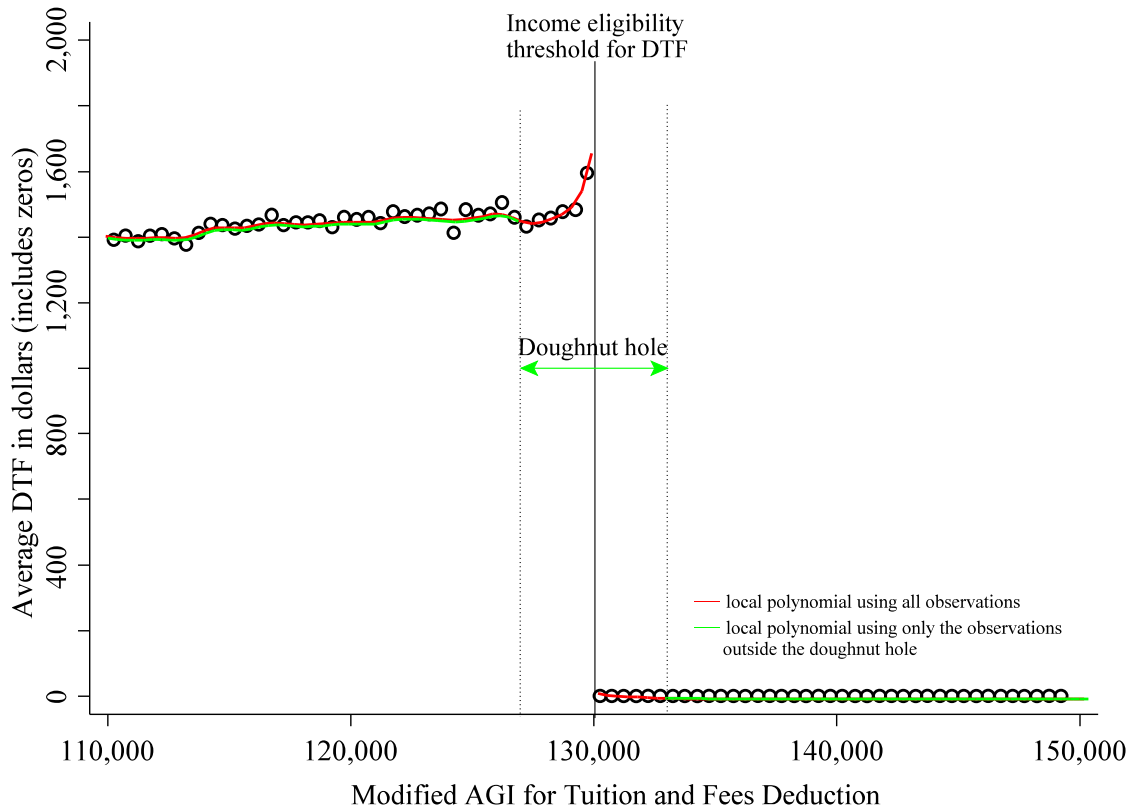

Notes: Figures show the probability of taking the DTF and average DTF in dollars as a function of modified adjusted gross income in year 1 (2002 and 2003) among married joint filers who had a child who would have graduated from high school in year 0 if he or she had progressed through secondary school on time. Average DTF includes zeros (non-takers). Each dot summarizes data in a $\$ 500$ interval. The figures also show smoothed values from gaussian kernel-weighted local polynomial regressions (degree 1, bandwidth 500) that include all observations or only those outside the doughnut hole. Source: de-identified tax data. 
Figure 4

Stylized illustration of a causal effect of the DTF (left panel) versus pure income management (right panel)

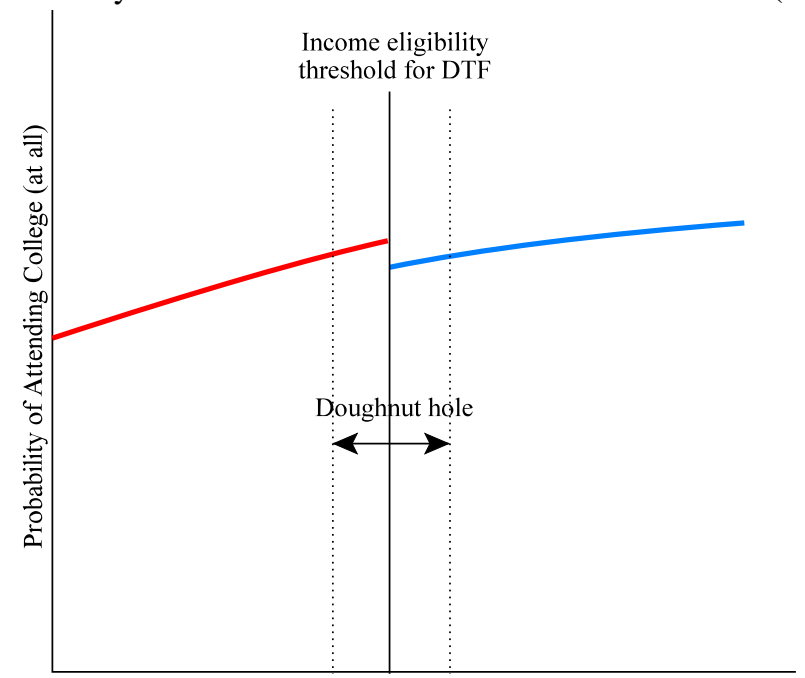

Modified AGI for Tuition and Fees Deduction

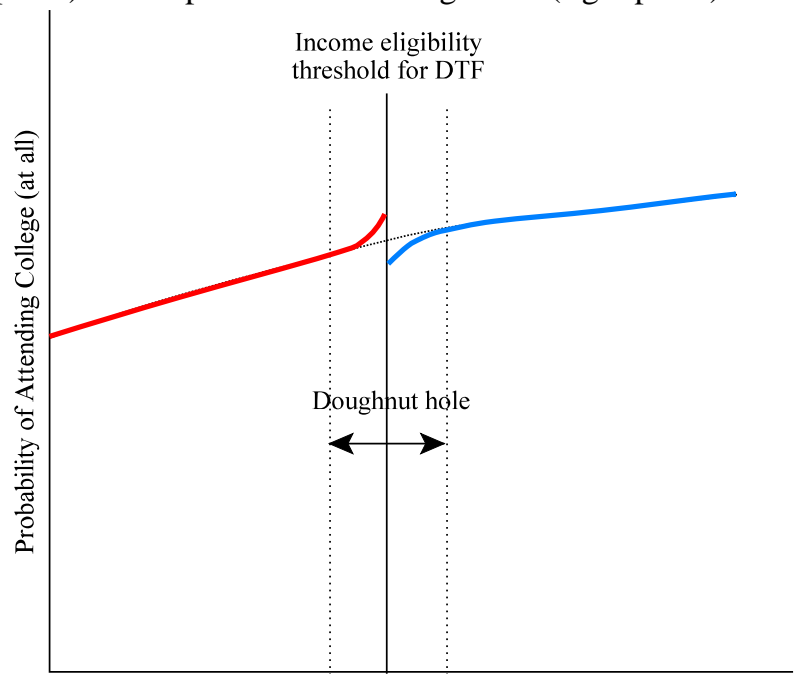

Modified AGI for Tuition and Fees Deduction 


\section{Figure 5}

Attending college and modified AGI at 2002-03 married eligibility threshold

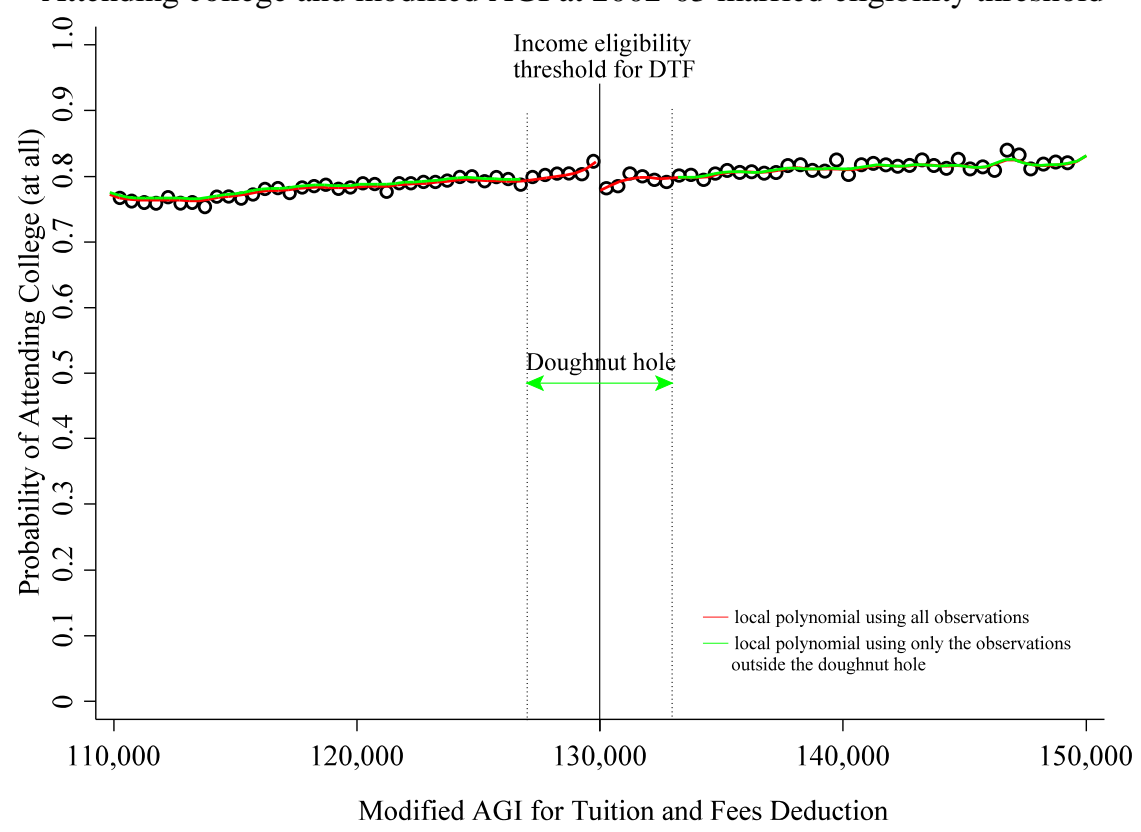

Figure 6

Four-year college and modified AGI at 2003-04 married eligibility threshold

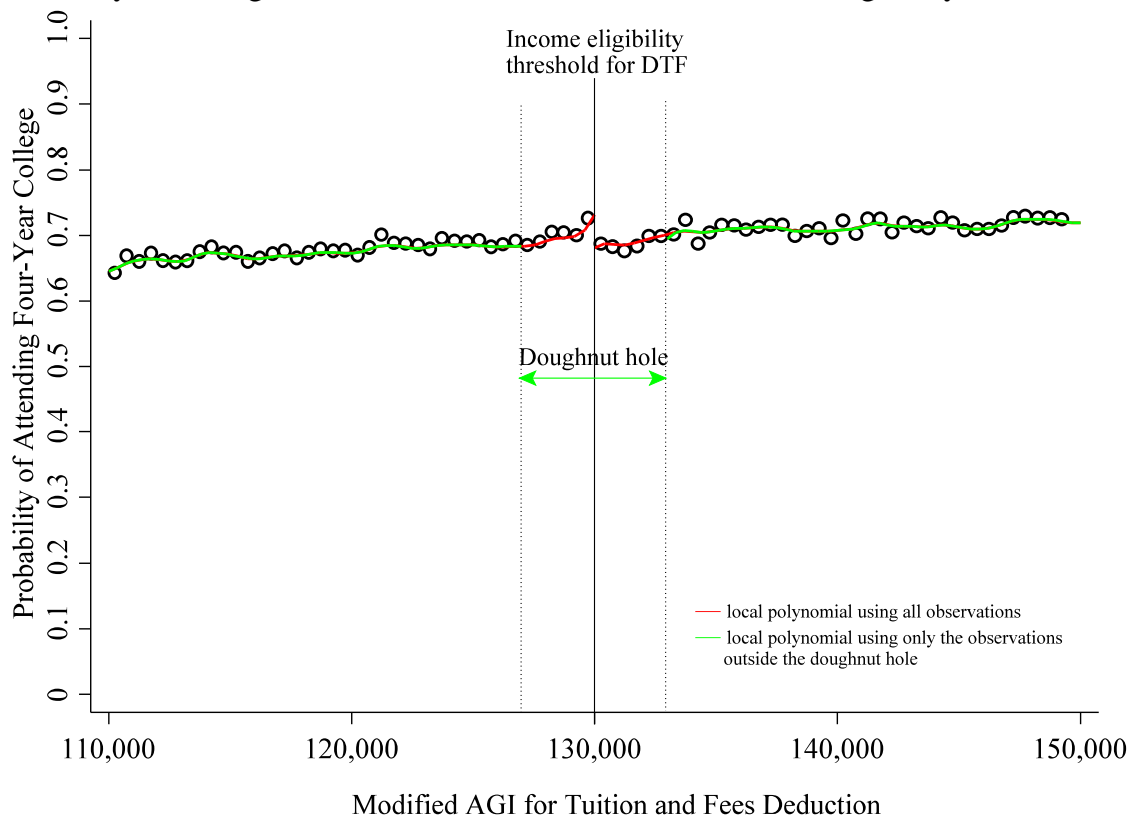

Notes: Figures show the probability of attending college (at all) and attending four-year college (conditional on attending at all) as a function of modified adjusted gross income in year 1 (2002 and 2003) among married joint filers who had a child who would have graduated from high school in year 0 if he or she had progressed through secondary school on time. Each dot summarizes data in a $\$ 500$ interval. The figures also show smoothed values from gaussian kernel-weighted local polynomial regressions (degree 1, bandwidth 500) that include all observations or only those outside the doughnut hole. Source: de-identified tax data. 


\section{Figure 7}

Attending college (at all) and modified AGI at the lower 2004-08 married eligibility threshold

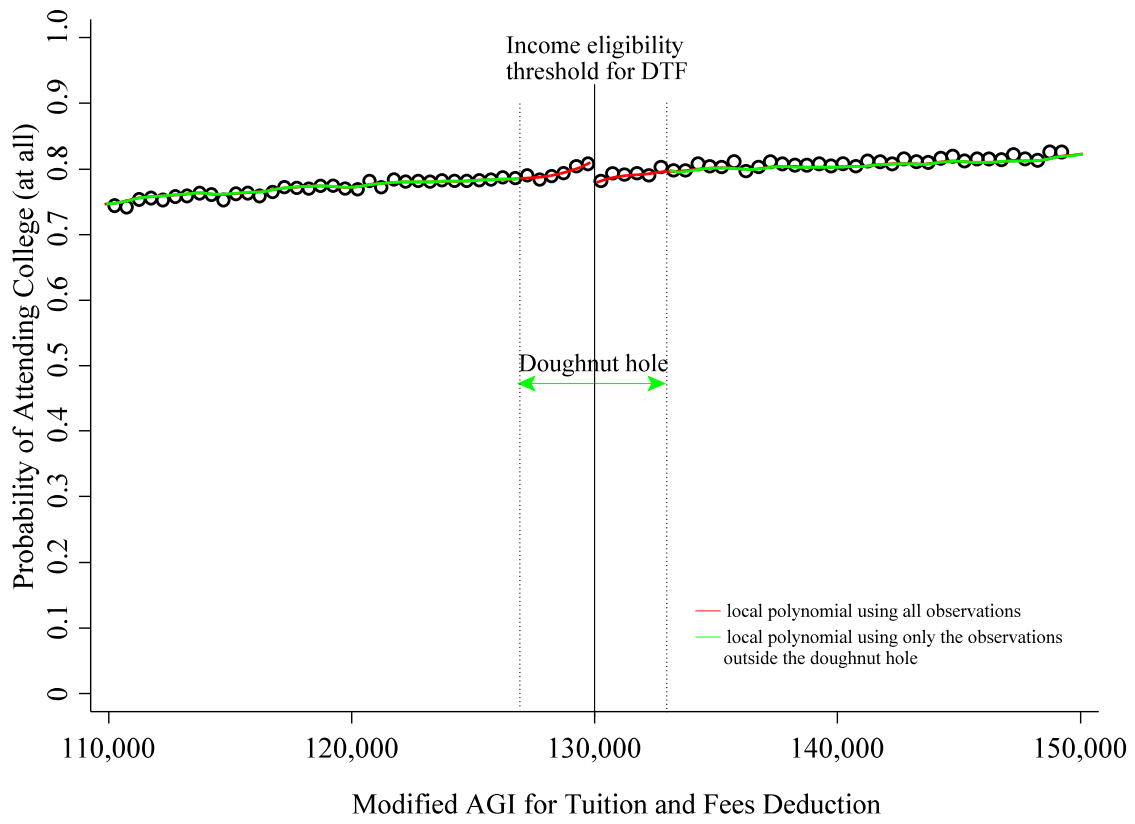

\section{Figure 8}

Attending faur-year college and modified AGI at the lower 2004-08 married eligibility threshold

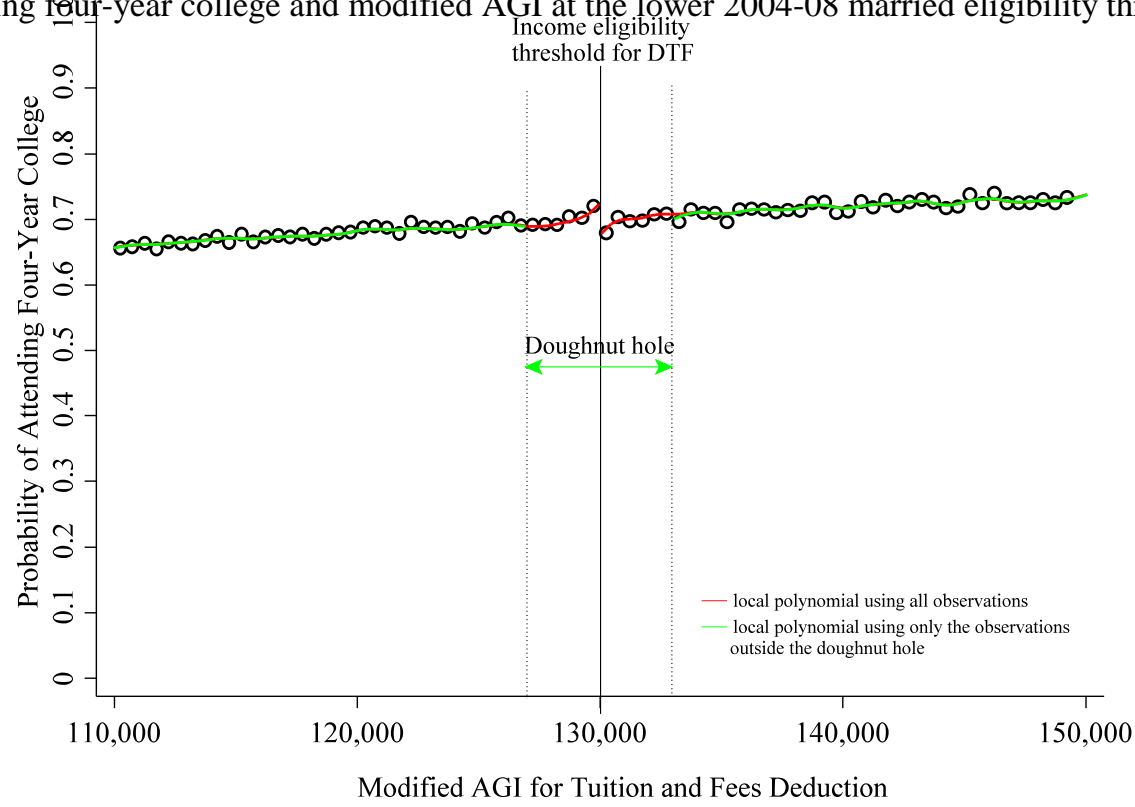

Notes: Figures show the probability of attending college (at all) and attending four-year college (conditional on attending at all) as a function of modified adjusted gross income in year 1 (2004 through 2008) among married joint filers who had a child who would have graduated from high school in year 0 if he or she had progressed through secondary school on time. Each dot summarizes data in a $\$ 500$ interval. The figures also show smoothed values from gaussian kernel-weighted local polynomial regressions (degree 1, bandwidth 500) that include all observations or only those outside the doughnut hole. Source: de-identified tax data. 
Table 1

College-Related Outcomes for the 2004 Cohort from Joint Filing Households

all outcomes are for year 1 except as noted

\begin{tabular}{|c|c|c|c|c|c|c|}
\hline $\begin{array}{l}\text { Modified } \\
\text { Adjusted } \\
\text { Gross } \\
\text { Income }\end{array}$ & $\begin{array}{l}\text { Number of } \\
\text { House- } \\
\text { holds }\end{array}$ & $\begin{array}{r}\text { Attend } \\
\text { Post- } \\
\text { secondary } \\
\text { at All }\end{array}$ & $\begin{array}{r}\text { Attend a } \\
\text { Four-Year } \\
\text { College }\end{array}$ & $\begin{array}{r}\text { Tuition and } \\
\text { Fees Paid } \\
(\$)\end{array}$ & $\begin{array}{r}\text { Core } \\
\text { Educational } \\
\text { Resources }\end{array}$ & $\begin{array}{r}\text { Interest Paid on } \\
\text { Student Loans } \\
\text { through year } 7 \\
(2011)\end{array}$ \\
\hline$\$ 0-25 \mathrm{k}$ & 223,253 & $32.0 \%$ & $54.5 \%$ & 8,829 & 14,731 & 778 \\
\hline$\$ 20-45 \mathrm{k}$ & 298,369 & $40.1 \%$ & $54.4 \%$ & 7,961 & 14,527 & 959 \\
\hline$\$ 45-55 \mathrm{k}$ & 174,107 & $48.6 \%$ & $55.6 \%$ & 7,801 & 14,564 & 1,171 \\
\hline$\$ 55-65 \mathrm{k}$ & 183,033 & $54.5 \%$ & $57.0 \%$ & 7,867 & 14,644 & 1,302 \\
\hline$\$ 65-70 \mathrm{k}$ & 90,682 & $58.8 \%$ & $58.2 \%$ & 8,404 & 14,895 & 1,390 \\
\hline$\$ 70-75 \mathrm{k}$ & 88,492 & $61.4 \%$ & $59.0 \%$ & 8,033 & 14,951 & 1,444 \\
\hline$\$ 75-80 \mathrm{k}$ & 85,350 & $63.5 \%$ & $59.7 \%$ & 8,617 & 15,220 & 1,494 \\
\hline$\$ 80-90 \mathrm{k}$ & 155,395 & $67.5 \%$ & $61.7 \%$ & 8,746 & 15,546 & 1,519 \\
\hline$\$ 90-110 \mathrm{k}$ & 236,533 & $72.7 \%$ & $64.7 \%$ & 10,332 & 16,182 & 1,548 \\
\hline$\$ 110-120 \mathrm{k}$ & 83,681 & $77.0 \%$ & $68.1 \%$ & 11,024 & 17,125 & 1,521 \\
\hline$\$ 120-130 \mathrm{k}$ & 66,986 & $79.4 \%$ & $70.2 \%$ & 13,236 & 17,753 & 1,491 \\
\hline$\$ 130-140 \mathrm{k}$ & 51,764 & $80.8 \%$ & $72.0 \%$ & 15,169 & 18,426 & 1,457 \\
\hline$\$ 140-150 \mathrm{k}$ & 41,564 & $82.1 \%$ & $74.2 \%$ & 15,399 & 19,050 & 1,384 \\
\hline$\$ 150-160 \mathrm{k}$ & 33,680 & $83.2 \%$ & $75.3 \%$ & 16,461 & 19,732 & 1,337 \\
\hline$\$ 160-170 \mathrm{k}$ & 26,518 & $83.7 \%$ & $76.3 \%$ & 17,067 & 20,168 & 1,242 \\
\hline$\$ 170-180 \mathrm{k}$ & 21,843 & $84.9 \%$ & $78.0 \%$ & 17,562 & 20,586 & 1,161 \\
\hline \$180k + & 189,049 & $87.4 \%$ & $84.2 \%$ & 27,031 & 25,096 & 709 \\
\hline
\end{tabular}

Notes: The 2004 cohort is the group of students who would be expected to graduate from high school in June 2004. A person is associated with a joint filing household if, when he is age 17 (and thus not independent) his household files jointly. We continue to associate each person with his age 17 household for the purpose of classification owing to the fact that, after age 17, filing status is endogenous to the person's enrollment in postsecondary school. Year 1 is the first full tax year after a person would be expected to graduate from high school if he started elementary school on time, according to his state's compulsory schooling laws, and progressed through school on schedule (with no retention in grade). Year 1 is the year in which people are most likely to be enrolled in postsecondary school. For on-time students, it corresponds to the spring of freshman year and fall of sophomore year in college.

Source: Authors' calculations based on de-identified tax data. 
Table 2

Effect of the DTF Threshold on Deduction Take-up in Year 1 quintic polynomial and $\$ 20,000$ bandwidth $(\$ 10,000$ for single filers)

\begin{tabular}{|c|c|c|c|c|c|c|}
\hline \multirow[b]{3}{*}{$\begin{array}{l}\text { base case with } \$ 3,000 \\
\text { doughtnut-hole ( } \$ 1,500 \text { for } \\
\text { single filers) } \\
\text { This case is unlikely to be } \\
\text { biased by income } \\
\text { management. }\end{array}$} & \multirow{2}{*}{$\begin{array}{l}2002 \& \\
2003 \\
\text { cohorts } \\
\$ 130,000 \\
\text { threshold }\end{array}$} & \multicolumn{2}{|c|}{$\begin{array}{r}2004 \text { through } 2008 \\
\text { cohorts }\end{array}$} & \multirow{2}{*}{$\begin{array}{l}2002 \& \\
2003 \\
\text { cohorts } \\
\$ 65,000 \\
\text { threshold }\end{array}$} & \multicolumn{2}{|c|}{$\begin{array}{r}2004 \text { through } 2008 \\
\text { cohorts }\end{array}$} \\
\hline & & $\begin{array}{r}\$ 130,000 \\
\text { threshold } \\
\text { (take } \\
\text { larger) }\end{array}$ & $\begin{array}{l}\$ 160,000 \\
\text { threshold }\end{array}$ & & $\begin{array}{r}\$ 65,000 \\
\text { threshold } \\
(\text { take } \\
\text { larger })\end{array}$ & $\begin{array}{r}\$ 80,000 \\
\text { threshold }\end{array}$ \\
\hline & $\begin{array}{r}0.584 * * * \\
(0.010)\end{array}$ & $\begin{array}{r}0.550 * * * \\
(0.006)\end{array}$ & $\begin{array}{r}0.640 * * * \\
(0.008)\end{array}$ & $\begin{array}{r}0.238 * * * \\
(0.013)\end{array}$ & $\begin{array}{r}0.192 * * * \\
(0.007)\end{array}$ & $\begin{array}{r}0.296 * * * \\
(0.011)\end{array}$ \\
\hline $\begin{array}{l}\$ 2,000 \text { doughnut-hole } \\
\text { (1000single) }\end{array}$ & $\begin{array}{r}0.576 \\
(0.007)\end{array}$ & $\begin{array}{r}0.547 \\
(0.004)\end{array}$ & $\begin{array}{r}0.642 \\
(0.006)\end{array}$ & $\begin{array}{r}0.232 \\
(0.009)\end{array}$ & $\begin{array}{r}0.197 \\
(0.005)\end{array}$ & $\begin{array}{r}0.295 \\
(0.008)\end{array}$ \\
\hline $\begin{array}{l}\$ 1,000 \text { doughnut-hole } \\
\text { (500single) }\end{array}$ & $\begin{array}{r}0.573 \\
(0.005)\end{array}$ & $\begin{array}{r}0.549 \\
(0.003)\end{array}$ & $\begin{array}{r}0.643 \\
(0.004)\end{array}$ & $\begin{array}{r}0.242 \\
(0.007)\end{array}$ & $\begin{array}{r}0.194 \\
(0.004)\end{array}$ & $\begin{array}{r}0.303 \\
(0.006)\end{array}$ \\
\hline$\$ 0$ doughnut-hole & $\begin{array}{r}0.586 \\
(0.004)\end{array}$ & $\begin{array}{r}0.560 \\
(0.002)\end{array}$ & $\begin{array}{r}0.648 \\
(0.003)\end{array}$ & $\begin{array}{r}0.258 \\
(0.005)\end{array}$ & $\begin{array}{r}0.198 \\
(0.003)\end{array}$ & $\begin{array}{r}0.308 \\
(0.005)\end{array}$ \\
\hline
\end{tabular}

Notes: The table shows regression discontinuity-based estimates of the effect of various income eligibility cut-offs on take-up of the DTF. Standard errors are in parentheses. The base case is shown in the first row and in bold. *** indicates that an estimate is statistically significantly different from zero at the 0.01 level. We do not show asterisks on estimates that employ doughnut-holes smaller than the base case because we know that those estimates suffer from reverse causality bias due to income management. Because there are two tiers of income eligibility in 2004 through 2008, the estimates in the columns headed "take larger" refer to the households taking up the larger deduction for which they qualify based on being just below an income cut-off. Appendix Table 3 shows results for narrower bandwidths and quartic polynomials.

Source: Authors' calculations based on de-identified tax data. 
Table 3

Effect of the DTF Threshold on the Deduction Amount in Year 1 (unconditional on taking it up) quintic polynomial and $\$ 20,000$ bandwidth $(\$ 10,000$ for single filers)

\begin{tabular}{|c|c|c|c|c|c|c|}
\hline \multirow[b]{3}{*}{$\begin{array}{l}\text { base case with } \$ 3,000 \\
\text { doughtnut-hole ( } \$ 1,500 \text { for } \\
\text { single filers) } \\
\text { This case is unlikely to be } \\
\text { biased by income } \\
\text { management. }\end{array}$} & \multirow{2}{*}{$\begin{array}{l}2002 \& \\
2003 \\
\text { cohorts } \\
\$ 130,000 \\
\text { threshold }\end{array}$} & \multicolumn{2}{|c|}{$\begin{array}{r}2004 \text { through } 2008 \\
\text { cohorts }\end{array}$} & \multirow{2}{*}{$\begin{array}{l}2002 \& \\
2003 \\
\text { cohorts } \\
\$ 65,000 \\
\text { threshold }\end{array}$} & \multicolumn{2}{|c|}{$\begin{array}{r}2004 \text { through } 2008 \\
\text { cohorts }\end{array}$} \\
\hline & & $\begin{array}{r}\$ 130,000 \\
\text { threshold } \\
\text { (take } \\
\text { larger) }\end{array}$ & $\begin{array}{l}\$ 160,000 \\
\text { threshold }\end{array}$ & & $\begin{array}{r}\$ 65,000 \\
\text { threshold } \\
(\text { take } \\
\text { larger })\end{array}$ & $\begin{array}{r}\$ 80,000 \\
\text { threshold }\end{array}$ \\
\hline & $\begin{array}{r}1573 * * * \\
(35)\end{array}$ & $\begin{array}{r}1023 * * * \\
(24)\end{array}$ & $\begin{array}{r}1199 * * * \\
(15)\end{array}$ & $\begin{array}{r}570 * * * \\
(31)\end{array}$ & $\begin{array}{r}361 * * * \\
(27)\end{array}$ & $\begin{array}{r}524 * * * \\
(21)\end{array}$ \\
\hline $\begin{array}{l}\$ 2,000 \text { doughnut-hole } \\
\text { (1000single) }\end{array}$ & $\begin{array}{r}1538 \\
(26)\end{array}$ & $\begin{array}{r}1018 \\
(18)\end{array}$ & $\begin{array}{r}1207 \\
(11)\end{array}$ & $\begin{array}{l}558 \\
(23)\end{array}$ & $\begin{array}{l}382 \\
(20)\end{array}$ & $\begin{array}{l}519 \\
(15)\end{array}$ \\
\hline $\begin{array}{l}\$ 1,000 \text { doughnut-hole } \\
\text { (500single) }\end{array}$ & $\begin{array}{r}1547 \\
(19)\end{array}$ & $\begin{array}{r}1039 \\
(13)\end{array}$ & $\begin{array}{r}1213 \\
(8)\end{array}$ & $\begin{array}{r}586 \\
(17)\end{array}$ & $\begin{array}{l}377 \\
(15)\end{array}$ & $\begin{array}{l}538 \\
(11)\end{array}$ \\
\hline$\$ 0$ doughnut-hole & $\begin{array}{r}1594 \\
(14)\end{array}$ & $\begin{array}{r}1103 \\
(10)\end{array}$ & $\begin{array}{r}1225 \\
(6)\end{array}$ & $\begin{array}{r}619 \\
(13)\end{array}$ & $\begin{array}{l}389 \\
(11)\end{array}$ & $\begin{array}{r}549 \\
(9)\end{array}$ \\
\hline $\begin{array}{l}\text { change in deduction } \\
\text { amount at the cutoff } \\
\text { conditional on taking it }\end{array}$ & 2646 & 1498 & 1860 & 2279 & 1178 & 1755 \\
\hline
\end{tabular}

Notes: The table shows regression discontinuity-based estimates of the effect of various income eligibility cut-offs on the amount of the DTF unconditional on taking it. Standard errors are in parentheses. The base case is shown in the first row and in bold. $* * *$ indicates that an estimate is statistically significantly different from zero at the 0.01 level. We do not show asterisks on estimates that employ doughnut-holes smaller than the base case because we know that those estimates suffer from reverse causality bias due to income management. Appendix Table 4 shows results for narrower bandwidths and quartic polynomials. The bottom row shows the change in the deduction amount at the cut-off for those households that take the DTF. These numbers are useful for understanding the degree to which households are taking the maximum possible DTF.

Source: Authors' calculations based on de-identified tax data. 
Table 4

Effect of the DTF Threshold on Deduction Take-up and Amount in Years 0 through 4, Base Case

\begin{tabular}{|c|c|c|c|c|c|c|}
\hline & $\begin{array}{r}2002 \& \\
2003 \\
\text { cohorts }\end{array}$ & \multicolumn{2}{|c|}{$\begin{array}{r}2004 \text { through } 2008 \\
\text { cohorts }\end{array}$} & $\begin{array}{r}2002 \& \\
2003 \\
\text { cohorts }\end{array}$ & \multicolumn{2}{|c|}{$\begin{array}{r}2004 \text { through } 2008 \\
\text { cohorts }\end{array}$} \\
\hline & $\begin{array}{l}\$ 130,000 \\
\text { threshold }\end{array}$ & $\begin{array}{l}\$ 130,000 \\
\text { threshold }\end{array}$ & $\begin{array}{l}\$ 160,000 \\
\text { threshold }\end{array}$ & $\begin{array}{r}\$ 65,000 \\
\text { threshold }\end{array}$ & $\begin{array}{r}\$ 65,000 \\
\text { threshold }\end{array}$ & $\begin{array}{r}\$ 80,000 \\
\text { threshold }\end{array}$ \\
\hline Take-up the deduction in Year 0 & $\begin{array}{r}0.511 * * * \\
(0.010)\end{array}$ & $\begin{array}{r}0.464 * * * \\
(0.006)\end{array}$ & $\begin{array}{r}0.566^{* * *} \\
(0.008)\end{array}$ & $\begin{array}{r}0.216^{* * * *} \\
(0.011)\end{array}$ & $\begin{array}{r}0.151 * * * \\
(0.006)\end{array}$ & $\begin{array}{r}0.243^{* * * *} \\
(0.010)\end{array}$ \\
\hline Take-up the deduction in Year 1 & $\begin{array}{r}0.584 * * * \\
(0.010)\end{array}$ & $\begin{array}{r}0.550 * * * \\
(0.006)\end{array}$ & $\begin{array}{r}0.640 * * * \\
(0.008)\end{array}$ & $\begin{array}{r}0.238 * * * \\
(0.013)\end{array}$ & $\begin{array}{r}0.192 * * * \\
(0.007)\end{array}$ & $\begin{array}{r}0.296^{* * * *} \\
(0.011)\end{array}$ \\
\hline Take-up the deduction in Year 2 & $\begin{array}{r}0.547 * * * \\
(0.010)\end{array}$ & $\begin{array}{r}0.542 * * * \\
(0.006)\end{array}$ & $\begin{array}{r}0.624 * * * \\
(0.008)\end{array}$ & $\begin{array}{r}0.234 * * * \\
(0.013)\end{array}$ & $\begin{array}{r}0.196 * * * \\
(0.007)\end{array}$ & $\begin{array}{r}0.271 * * * \\
(0.011)\end{array}$ \\
\hline Take-up the deduction in Year 3 & $\begin{array}{r}0.511 * * * \\
(0.010)\end{array}$ & $\begin{array}{r}0.509 * * * \\
(0.006)\end{array}$ & $\begin{array}{r}0.576^{* * * *} \\
(0.008)\end{array}$ & $\begin{array}{r}0.205^{* * *} \\
(0.012)\end{array}$ & $\begin{array}{r}0.158^{* * * *} \\
(0.006)\end{array}$ & $\begin{array}{r}0.244 * * * \\
(0.011)\end{array}$ \\
\hline Take-up the deduction in Year 4 & $\begin{array}{r}0.440 * * * \\
(0.010)\end{array}$ & $\begin{array}{r}0.447 * * * \\
(0.006)\end{array}$ & $\begin{array}{r}0.503 * * * \\
(0.008)\end{array}$ & $\begin{array}{r}0.191 * * * \\
(0.012)\end{array}$ & $\begin{array}{r}0.137 * * * \\
(0.006)\end{array}$ & $\begin{array}{r}0.204^{* * * *} \\
(0.010)\end{array}$ \\
\hline $\begin{array}{l}\text { Deduction amount (unconditional } \\
\text { on attending) in Year } 0\end{array}$ & $\begin{array}{r}1308 * * * \\
(32)\end{array}$ & $\begin{array}{r}856 * * * \\
(24)\end{array}$ & $\begin{array}{r}1035 * * * \\
(15)\end{array}$ & $\begin{array}{r}499 * * * \\
(29)\end{array}$ & $\begin{array}{r}273 * * * * \\
(25)\end{array}$ & $\begin{array}{r}432 * * * \\
(18)\end{array}$ \\
\hline $\begin{array}{l}\text { Deduction amount (unconditional } \\
\text { on attending) in Year } 1\end{array}$ & $\begin{array}{r}1573 * * * \\
(35)\end{array}$ & $\begin{array}{r}1023 * * * \\
(24)\end{array}$ & $\begin{array}{r}1199 * * * \\
(15)\end{array}$ & $\begin{array}{r}570^{* * * *} \\
(31)\end{array}$ & $\begin{array}{r}361^{* * *} \\
(27)\end{array}$ & $\begin{array}{r}524 * * * \\
(21)\end{array}$ \\
\hline $\begin{array}{l}\text { Deduction amount (unconditional } \\
\text { on attending) in Year } 2\end{array}$ & $\begin{array}{r}1487 * * * \\
(28)\end{array}$ & $\begin{array}{r}1033 * * * \\
(25)\end{array}$ & $\begin{array}{r}1178 * * * \\
(15)\end{array}$ & $\begin{array}{r}597 * * * \\
(32)\end{array}$ & $\begin{array}{r}405 * * * \\
(27)\end{array}$ & $\begin{array}{r}490 * * * \\
(20)\end{array}$ \\
\hline $\begin{array}{l}\text { Deduction amount (unconditional } \\
\text { on attending) in Year } 3\end{array}$ & $\begin{array}{r}1385 * * * \\
(28)\end{array}$ & $\begin{array}{r}997 * * * \\
(25)\end{array}$ & $\begin{array}{r}1082 * * * \\
(16)\end{array}$ & $\begin{array}{r}521 * * * \\
(31)\end{array}$ & $\begin{array}{r}278 * * * \\
(31)\end{array}$ & $\begin{array}{r}449 * * * \\
(20)\end{array}$ \\
\hline $\begin{array}{l}\text { Deduction amount (unconditional } \\
\text { on attending) in Year } 4\end{array}$ & $\begin{array}{r}1189 * * * \\
(28)\end{array}$ & $\begin{array}{r}839 * * * \\
(25)\end{array}$ & $\begin{array}{r}953 * * * \\
(16)\end{array}$ & $\begin{array}{r}483 * * * \\
(30)\end{array}$ & $\begin{array}{r}264 * * * \\
(26)\end{array}$ & $\begin{array}{r}373 * * * \\
(19)\end{array}$ \\
\hline
\end{tabular}

Notes: The table shows regression discontinuity-based estimates of the effect of various income eligibility cut-offs on take-up of the DTF and the amount of the DTF unconditional on taking it. Standard errors are in parentheses. *** indicates that an estimate is statistically significantly different from zero at the 0.01 level. Only base case estimates, which are unlikely to suffer from reverse causality bias, are shown. (See text and Tables 2 and 3 for the base case specification.)

Source: Authors' calculations based on de-identified tax data. 
Table 5

Effect of the DTF Threshold on College Attendance in Year 1 quintic polynomial and $\$ 20,000$ bandwidth $(\$ 10,000$ for single filers)

\begin{tabular}{|c|c|c|c|c|c|c|}
\hline \multirow[b]{3}{*}{$\begin{array}{l}\text { base case with } \$ 3,000 \\
\text { doughtnut-hole ( } \$ 1,500 \text { for } \\
\text { single filers) } \\
\text { This case is unlikely to be } \\
\text { biased by income } \\
\text { management. }\end{array}$} & \multirow{2}{*}{$\begin{array}{l}2002 \& \\
2003 \\
\text { cohorts } \\
\$ 130,000 \\
\text { threshold }\end{array}$} & \multicolumn{2}{|c|}{$\begin{array}{r}2004 \text { through } 2008 \\
\text { cohorts }\end{array}$} & \multirow{2}{*}{$\begin{array}{l}2002 \& \\
2003 \\
\text { cohorts } \\
\$ 65,000 \\
\text { threshold }\end{array}$} & \multicolumn{2}{|c|}{$\begin{array}{r}2004 \text { through } 2008 \\
\text { cohorts }\end{array}$} \\
\hline & & $\begin{array}{r}\$ 130,000 \\
\text { threshold } \\
(\text { take } \\
\text { larger) }\end{array}$ & $\begin{array}{l}\$ 160,000 \\
\text { threshold }\end{array}$ & & $\begin{array}{r}\$ 65,000 \\
\text { threshold } \\
(\text { take } \\
\text { larger })\end{array}$ & $\begin{array}{r}\$ 80,000 \\
\text { threshold }\end{array}$ \\
\hline & $\begin{array}{r}-\mathbf{0 . 0 0 7} \\
(0.009)\end{array}$ & $\begin{array}{r}-0.003 \\
(0.006)\end{array}$ & $\begin{array}{r}0.000 \\
(0.008)\end{array}$ & $\begin{array}{r}-0.005 \\
(0.007)\end{array}$ & $\begin{array}{r}0.005 \\
(0.004)\end{array}$ & $\begin{array}{r}-0.000 \\
(0.006)\end{array}$ \\
\hline $\begin{array}{l}\$ 2,000 \text { doughnut-hole } \\
\text { (1000single) }\end{array}$ & $\begin{array}{r}0.005 \\
(0.007)\end{array}$ & $\begin{array}{r}0.001 \\
(0.004)\end{array}$ & $\begin{array}{r}0.009 \\
(0.006)\end{array}$ & $\begin{array}{r}-0.000 \\
(0.014)\end{array}$ & $\begin{array}{r}0.010 \\
(0.008)\end{array}$ & $\begin{array}{r}0.003 \\
(0.011)\end{array}$ \\
\hline $\begin{array}{l}\$ 1,000 \text { doughnut-hole } \\
\text { (500single) }\end{array}$ & $\begin{array}{r}0.005 \\
(0.005)\end{array}$ & $\begin{array}{r}0.003 \\
(0.003)\end{array}$ & $\begin{array}{r}0.007 \\
(0.004)\end{array}$ & $\begin{array}{r}0.003 \\
(0.010)\end{array}$ & $\begin{array}{r}0.017 \\
(0.006)\end{array}$ & $\begin{array}{r}0.005 \\
(0.008)\end{array}$ \\
\hline$\$ 0$ doughnut-hole & $\begin{array}{r}0.019 \\
(0.004)\end{array}$ & $\begin{array}{r}0.012 \\
(0.003)\end{array}$ & $\begin{array}{r}0.007 \\
(0.003)\end{array}$ & $\begin{array}{r}0.015 \\
(0.008)\end{array}$ & $\begin{array}{r}0.019 \\
(0.005)\end{array}$ & $\begin{array}{r}0.012 \\
(0.006)\end{array}$ \\
\hline
\end{tabular}

Notes: The table shows regression discontinuity-based estimates of the effect of various income eligibility cut-offs on college attendance (at all). Standard errors are in parentheses. The base case is shown in the first row and in bold. $* * *, * *$, or $*$ indicates that an estimate is statistically significantly different from zero at the $0.01,0.05$, or 0.10 level. We do not show asterisks on estimates that employ doughnut-holes smaller than the base case because we know that those estimates suffer from reverse causality bias due to income management. Appendix Table 5 shows results for narrower bandwidths and quartic polynomials.

Source: Authors' calculations based on de-identified tax data. 
Table 6

Effect of the DTF Threshold on Attending Four-Year College (conditional on attending at all) in Year 1 quintic polynomial and $\$ 20,000$ bandwidth ( $\$ 10,000$ for single filers)

\begin{tabular}{|c|c|c|c|c|c|c|}
\hline \multirow[b]{3}{*}{$\begin{array}{l}\text { base case with } \$ 3,000 \\
\text { doughtnut-hole ( } \$ 1,500 \text { for } \\
\text { single filers) } \\
\text { This case is unlikely to be } \\
\text { biased by income } \\
\text { management. }\end{array}$} & \multirow{2}{*}{$\begin{array}{l}2002 \& \\
2003 \\
\text { cohorts } \\
\$ 130,000 \\
\text { threshold }\end{array}$} & \multicolumn{2}{|c|}{$\begin{array}{r}2004 \text { through } 2008 \\
\text { cohorts }\end{array}$} & \multirow{2}{*}{$\begin{array}{l}2002 \& \\
2003 \\
\text { cohorts } \\
\$ 65,000 \\
\text { threshold }\end{array}$} & \multicolumn{2}{|c|}{$\begin{array}{r}2004 \text { through } 2008 \\
\text { cohorts }\end{array}$} \\
\hline & & $\begin{array}{r}\$ 130,000 \\
\text { threshold } \\
(\text { take } \\
\text { larger) }\end{array}$ & $\begin{array}{l}\$ 160,000 \\
\text { threshold }\end{array}$ & & $\begin{array}{r}\$ 65,000 \\
\text { threshold } \\
(\text { take } \\
\text { larger })\end{array}$ & $\begin{array}{r}\$ 80,000 \\
\text { threshold }\end{array}$ \\
\hline & $\begin{array}{r}-0.003 \\
(0.010)\end{array}$ & $\begin{array}{r}-0.002 \\
(0.006)\end{array}$ & $\begin{array}{r}0.001 \\
(0.008)\end{array}$ & $\begin{array}{r}0.007 \\
(\mathbf{0 . 0 1 1 )}\end{array}$ & $\begin{array}{r}0.002 \\
(0.007)\end{array}$ & $\begin{array}{r}0.003 \\
(0.009)\end{array}$ \\
\hline $\begin{array}{l}\$ 2,000 \text { doughnut-hole } \\
\text { (1000single) }\end{array}$ & $\begin{array}{r}-0.003 \\
(0.010)\end{array}$ & $\begin{array}{r}-0.002 \\
(0.006)\end{array}$ & $\begin{array}{r}0.001 \\
(0.008)\end{array}$ & $\begin{array}{r}0.025 \\
(0.022)\end{array}$ & $\begin{array}{r}0.003 \\
(0.013)\end{array}$ & $\begin{array}{r}0.016 \\
(0.017)\end{array}$ \\
\hline $\begin{array}{l}\$ 1,000 \text { doughnut-hole } \\
\text { (500single) }\end{array}$ & $\begin{array}{r}0.019 \\
(0.008)\end{array}$ & $\begin{array}{r}0.004 \\
(0.005)\end{array}$ & $\begin{array}{r}-0.000 \\
(0.006)\end{array}$ & $\begin{array}{r}0.016 \\
(0.016)\end{array}$ & $\begin{array}{r}0.012 \\
(0.010)\end{array}$ & $\begin{array}{r}0.012 \\
(0.013)\end{array}$ \\
\hline$\$ 0$ doughnut-hole & $\begin{array}{r}0.027 \\
(0.006)\end{array}$ & $\begin{array}{r}0.014 \\
(0.004)\end{array}$ & $\begin{array}{r}0.008 \\
(0.005)\end{array}$ & $\begin{array}{r}0.017 \\
(0.012)\end{array}$ & $\begin{array}{r}0.013 \\
(0.007)\end{array}$ & $\begin{array}{r}0.015 \\
(0.010)\end{array}$ \\
\hline
\end{tabular}

Notes: The table shows regression discontinuity-based estimates of the effect of various income eligibility cut-offs on four-year college attendance (conditional on attending at all). Standard errors are in parentheses. The base case is shown in the first row and in bold. $* * *, * *$, or $*$ indicates that an estimate is statistically significantly different from zero at the $0.01,0.05$, or 0.10 level. We do not show asterisks on estimates that employ doughnut-holes smaller than the base case because we know that those estimates suffer from reverse causality bias due to income management. Appendix Table 6 shows results for narrower bandwidths and quartic polynomials.

Source: Authors' calculations based on de-identified tax data. 
Table 7

Effect of the DTF Threshold on Attending College and Four-Year College in Years 0 through 4, Base Case

\begin{tabular}{|c|c|c|c|c|c|c|}
\hline & $\begin{array}{r}2002 \& \\
2003\end{array}$ & \multicolumn{2}{|c|}{$\begin{array}{r}2004 \text { through } 2008 \\
\text { cohorts }\end{array}$} & $\begin{array}{r}2002 \& \\
2003\end{array}$ & \multicolumn{2}{|c|}{$\begin{array}{r}2004 \text { through } 2008 \\
\text { cohorts }\end{array}$} \\
\hline & $\begin{array}{r}\text { cohorts } \\
\$ 130,000 \\
\text { threshold }\end{array}$ & $\begin{array}{l}\$ 130,000 \\
\text { threshold }\end{array}$ & $\begin{array}{l}\$ 160,000 \\
\text { threshold }\end{array}$ & $\begin{array}{r}\text { cohorts } \\
\$ 65,000 \\
\text { threshold }\end{array}$ & $\begin{array}{r}\$ 65,000 \\
\text { threshold }\end{array}$ & $\begin{array}{r}\$ 80,000 \\
\text { threshold }\end{array}$ \\
\hline Attending college (at all) in Year 0 & $\begin{array}{l}-0.004 \\
(0.012)\end{array}$ & $\begin{array}{r}0.016^{* *} \\
(0.007)\end{array}$ & $\begin{array}{r}0.010 \\
(0.010)\end{array}$ & $\begin{array}{r}0.021 \\
(0.017)\end{array}$ & $\begin{array}{l}0.020 * \\
(0.012)\end{array}$ & $\begin{array}{r}0.008 \\
(0.015)\end{array}$ \\
\hline Attending college (at all) in Year 1 & $\begin{array}{r}-0.007 \\
(0.010)\end{array}$ & $\begin{array}{r}-0.003 \\
(0.006)\end{array}$ & $\begin{array}{r}0.000 \\
(0.008)\end{array}$ & $\begin{array}{r}-0.008 \\
(0.018)\end{array}$ & $\begin{array}{r}0.014 \\
(0.011)\end{array}$ & $\begin{array}{r}0.015 \\
(0.015)\end{array}$ \\
\hline Attending college (at all) in Year 2 & $\begin{array}{r}0.001 \\
(0.010)\end{array}$ & $\begin{array}{r}0.010 \\
(0.006)\end{array}$ & $\begin{array}{r}0.015^{*} \\
(0.008)\end{array}$ & $\begin{array}{r}0.026 \\
(0.019)\end{array}$ & $\begin{array}{r}0.008 \\
(0.011)\end{array}$ & $\begin{array}{r}0.008 \\
(0.015)\end{array}$ \\
\hline Attending college (at all) in Year 3 & $\begin{array}{r}-0.013 \\
(0.011)\end{array}$ & $\begin{array}{r}-0.000 \\
(0.007)\end{array}$ & $\begin{array}{r}0.005 \\
(0.009)\end{array}$ & $\begin{array}{r}0.012 \\
(0.019)\end{array}$ & $\begin{array}{l}-0.011 \\
(0.012)\end{array}$ & $\begin{array}{r}0.009 \\
(0.016)\end{array}$ \\
\hline Attending college (at all) in Year 4 & $\begin{array}{r}0.034 * * \\
(0.012)\end{array}$ & $\begin{array}{r}-0.001 \\
(0.007)\end{array}$ & $\begin{array}{r}0.002 \\
(0.010)\end{array}$ & $\begin{array}{r}0.016 \\
(0.019)\end{array}$ & $\begin{array}{r}0.007 \\
(0.012)\end{array}$ & $\begin{array}{r}-0.002 \\
(0.016)\end{array}$ \\
\hline $\begin{array}{l}\text { Four-year college (conditional on } \\
\text { attending at all) in Year } 0\end{array}$ & $\begin{array}{r}0.009 \\
(0.017)\end{array}$ & $\begin{array}{r}0.006 \\
(0.008)\end{array}$ & $\begin{array}{l}-0.008 \\
(0.013)\end{array}$ & $\begin{array}{r}0.039 \\
(0.034)\end{array}$ & $\begin{array}{r}0.019 \\
(0.020)\end{array}$ & $\begin{array}{r}-0.007 \\
(0.026)\end{array}$ \\
\hline $\begin{array}{l}\text { Four-year college (conditional on } \\
\text { attending at all) in Year } 1\end{array}$ & $\begin{array}{r}-0.002 \\
(0.014)\end{array}$ & $\begin{array}{r}0.009 \\
(0.009)\end{array}$ & $\begin{array}{r}0.006 \\
(0.011)\end{array}$ & $\begin{array}{r}-0.004 \\
(0.029)\end{array}$ & $\begin{array}{r}-0.021 \\
(0.017)\end{array}$ & $\begin{array}{l}-0.002 \\
(0.023)\end{array}$ \\
\hline $\begin{array}{l}\text { Four-year college (conditional on } \\
\text { attending at all) in Year } 2\end{array}$ & $\begin{array}{r}0.011 \\
(0.015)\end{array}$ & $\begin{array}{r}-0.000 \\
(0.009)\end{array}$ & $\begin{array}{r}-0.011 \\
(0.011)\end{array}$ & $\begin{array}{r}0.030 \\
(0.030)\end{array}$ & $\begin{array}{r}0.026 \\
(0.018)\end{array}$ & $\begin{array}{r}0.008 \\
(0.023)\end{array}$ \\
\hline $\begin{array}{l}\text { Four-year college (conditional on } \\
\text { attending at all) in Year } 3\end{array}$ & $\begin{array}{r}0.012 \\
(0.015)\end{array}$ & $\begin{array}{r}-0.000 \\
(0.009)\end{array}$ & $\begin{array}{r}-0.008 \\
(0.011)\end{array}$ & $\begin{array}{r}-0.020 \\
(0.030)\end{array}$ & $\begin{array}{l}-0.026 \\
(0.019)\end{array}$ & $\begin{array}{r}-0.017 \\
(0.023)\end{array}$ \\
\hline $\begin{array}{l}\text { Four-year college (conditional on } \\
\text { attending at all) in Year } 4\end{array}$ & $\begin{array}{r}0.006 \\
(0.015)\end{array}$ & $\begin{array}{r}0.004 \\
(0.009)\end{array}$ & $\begin{array}{r}0.019 \\
(0.012)\end{array}$ & $\begin{array}{r}0.026 \\
(0.031)\end{array}$ & $\begin{array}{r}0.019 \\
(0.019)\end{array}$ & $\begin{array}{r}0.023 \\
(0.025)\end{array}$ \\
\hline
\end{tabular}

Notes: The table shows regression discontinuity-based estimates of the effect of various income eligibility cut-offs on college attendance (at all) and attending four-year college (conditional on attending). Standard errors are in parentheses. Only base case estimates, which are unlikely to suffer from reverse causality bias, are shown. (See text and Tables 5 and 6 for the base case specification.) $* * *, * *$, or * indicates that an estimate is statistically significantly different from zero at the $0.01,0.05$, or 0.10 level. Source: Authors' calculations based on de-identified tax data. 
Table 8

Effect of the DTF Threshold on Various College-Related Outcomes, Year 1, Base Case all outcomes are conditional on attending college at all

\begin{tabular}{|c|c|c|c|c|c|c|}
\hline & $\begin{array}{r}2002 \& \\
2003 \\
\text { cohorts }\end{array}$ & 2004 th & $\begin{array}{r}\text { rough } 2008 \\
\text { cohorts } \\
\text { (see notes) }\end{array}$ & $\begin{array}{r}2002 \& \\
2003 \\
\text { cohorts }\end{array}$ & 2004 th & $\begin{array}{r}\text { rough } 2008 \\
\text { cohorts } \\
\text { (see notes) }\end{array}$ \\
\hline & $\begin{array}{l}\$ 130,000 \\
\text { threshold }\end{array}$ & $\begin{array}{l}\$ 130,000 \\
\text { threshold }\end{array}$ & $\begin{array}{l}\$ 160,000 \\
\text { threshold }\end{array}$ & $\begin{array}{r}\$ 65,000 \\
\text { threshold }\end{array}$ & $\begin{array}{r}\$ 65,000 \\
\text { threshold }\end{array}$ & $\begin{array}{r}\$ 80,000 \\
\text { threshold }\end{array}$ \\
\hline Attending college full-time in Year 1 & $\begin{array}{r}-0.014 \\
(0.011)\end{array}$ & $\begin{array}{r}-0.004 \\
(0.007)\end{array}$ & $\begin{array}{r}0.001 \\
(0.009)\end{array}$ & $\begin{array}{r}-0.016 \\
(0.018)\end{array}$ & $\begin{array}{r}0.006 \\
(0.011)\end{array}$ & $\begin{array}{r}0.002 \\
(0.016)\end{array}$ \\
\hline Two-year college in Year 1 & $\begin{array}{r}-0.000 \\
(0.015)\end{array}$ & $\begin{array}{r}-0.009 \\
(0.009)\end{array}$ & $\begin{array}{r}-0.007 \\
(0.011)\end{array}$ & $\begin{array}{r}0.004 \\
(0.029)\end{array}$ & $\begin{array}{r}0.023 \\
(0.017)\end{array}$ & $\begin{array}{r}0.006 \\
(0.023)\end{array}$ \\
\hline $\begin{array}{l}\text { Instructional spending of the college } \\
\text { attended in Year } 1\end{array}$ & $\begin{array}{r}-50 \\
(247)\end{array}$ & $\begin{array}{l}139 \\
(98)\end{array}$ & $\begin{array}{r}119 \\
(143)\end{array}$ & $\begin{array}{r}-144 \\
(424)\end{array}$ & $\begin{array}{r}-214 \\
(168)\end{array}$ & $\begin{array}{r}-192 \\
(233)\end{array}$ \\
\hline $\begin{array}{l}\text { Core educational spending of the } \\
\text { college attended in Year } 1\end{array}$ & $\begin{array}{r}-73 \\
(476)\end{array}$ & $\begin{array}{r}215 \\
(178)\end{array}$ & $\begin{array}{r}177 \\
(256)\end{array}$ & $\begin{array}{r}-449 \\
(845)\end{array}$ & $\begin{array}{r}-642 \\
(307)\end{array}$ & $\begin{array}{r}-11 \\
(425)\end{array}$ \\
\hline $\begin{array}{l}\text { "Sticker price" tuition and fees of the } \\
\text { college attended in Year } 1\end{array}$ & $\begin{array}{r}-271 \\
(350)\end{array}$ & $\begin{array}{r}209 \\
(181)\end{array}$ & $\begin{array}{r}289 \\
(259)\end{array}$ & $\begin{array}{r}309 \\
(595)\end{array}$ & $\begin{array}{r}-284 \\
(309)\end{array}$ & $\begin{array}{r}-36 \\
(430)\end{array}$ \\
\hline Total tuition paid in Year 1 & $\begin{array}{r}149 * * \\
(65)\end{array}$ & $\begin{array}{r}171 \\
(152)\end{array}$ & $\begin{array}{r}79 \\
(221)\end{array}$ & $\begin{array}{r}-10 \\
(107)\end{array}$ & $\begin{array}{r}-151 \\
(256)\end{array}$ & $\begin{array}{r}234 \\
(360)\end{array}$ \\
\hline $\begin{array}{l}\text { Total grants and scholarships in Year } \\
1\end{array}$ & $\begin{array}{r}72 \\
(90)\end{array}$ & $\begin{array}{r}24 \\
(84)\end{array}$ & $\begin{array}{r}53 \\
(113)\end{array}$ & $\begin{array}{r}239 \\
(193)\end{array}$ & $\begin{array}{r}-249 \\
(175)\end{array}$ & $\begin{array}{r}45 \\
(228)\end{array}$ \\
\hline $\begin{array}{l}\text { Student loan interest paid in Years } 1 \\
\text { through } 7\end{array}$ & $\begin{array}{r}29 \\
(74)\end{array}$ & $\begin{array}{l}-56 \\
(87)\end{array}$ & $\begin{array}{r}-62 \\
(122)\end{array}$ & $\begin{array}{r}41 \\
(89)\end{array}$ & $\begin{array}{r}-30 \\
(100)\end{array}$ & $\begin{array}{r}-230 \\
(157)\end{array}$ \\
\hline
\end{tabular}

Notes: The table shows regression discontinuity-based estimates of the effect of various income eligibility cut-offs on college-related outcomes. Standard errors are in parentheses. Only base case estimates, which are unlikely to suffer from reverse causality bias, are shown. (See text and Tables 5 and 6 for the base case specification.) ***, **, or * indicates that an estimate is statistically significantly different from zero at the $0.01,0.05$, or 0.10 level. Only the 2004 and 2005 cohorts are used for the estimates of student loan interest paid in years 1 through 7 .

Source: Authors' calculations based on de-identified tax data. 
Table 9

Effect of Current and Lagged DTF Eligibility on Attending College and Four-Year College $\$ 20,000$ Bandwidth, Quintic Polynomial

\begin{tabular}{|c|c|c|c|c|}
\hline & $\begin{array}{r}2002-2008 \\
\text { cohorts }\end{array}$ & $\begin{array}{r}2002-2008 \\
\text { cohorts }\end{array}$ & $\begin{array}{r}2004 \& 2007 \\
\text { cohorts }\end{array}$ & $\begin{array}{r}2004-2008 \\
\text { cohorts }\end{array}$ \\
\hline & $\begin{array}{l}\$ 130,000 \\
\text { threshold }\end{array}$ & $\begin{array}{r}\$ 65,000 \\
\text { threshold }\end{array}$ & $\begin{array}{l}\$ 160,000 \\
\text { threshold }\end{array}$ & $\begin{array}{r}\$ 80,000 \\
\text { threshold }\end{array}$ \\
\hline \multicolumn{5}{|l|}{ Attending college at all } \\
\hline Eligible for DTF in current year (year 1) & $\begin{array}{r}0.003 \\
(0.008)\end{array}$ & $\begin{array}{r}0.002 \\
(0.016)\end{array}$ & $\begin{array}{l}0.028^{*} \\
(0.016)\end{array}$ & $\begin{array}{r}0.012 \\
(0.032)\end{array}$ \\
\hline Eligible for DTF in prior year (year 0) & $\begin{array}{r}-0.002 \\
(0.009)\end{array}$ & $\begin{array}{r}0.008 \\
(0.017)\end{array}$ & $\begin{array}{r}0.011 \\
(0.016)\end{array}$ & $\begin{array}{r}-0.016 \\
(0.033)\end{array}$ \\
\hline Eligible for DTF in current year (year 2) & $\begin{array}{r}0.012 \\
(0.009)\end{array}$ & $\begin{array}{r}0.027 \\
(0.017)\end{array}$ & $\begin{array}{r}-0.000 \\
(0.016)\end{array}$ & $\begin{array}{r}0.005 \\
(0.033)\end{array}$ \\
\hline Eligible for DTF in prior year (year 1) & $\begin{array}{l}-0.013 \\
(0.009)\end{array}$ & $\begin{array}{r}0.007 \\
(0.017)\end{array}$ & $\begin{array}{r}0.008 \\
(0.017)\end{array}$ & $\begin{array}{r}-0.007 \\
(0.034)\end{array}$ \\
\hline \multicolumn{5}{|l|}{ Four-year college attendance } \\
\hline Eligible for DTF in current year (year 1) & $\begin{array}{r}0.010 \\
(0.013)\end{array}$ & $\begin{array}{r}-0.025 \\
(0.025)\end{array}$ & $\begin{array}{r}0.011 \\
(0.023)\end{array}$ & $\begin{array}{r}-0.057 \\
(0.048)\end{array}$ \\
\hline Eligible for DTF in prior year (year 0) & $\begin{array}{r}0.006 \\
(0.013)\end{array}$ & $\begin{array}{r}0.031 \\
(0.026)\end{array}$ & $\begin{array}{r}-0.028 \\
(0.024)\end{array}$ & $\begin{array}{r}-0.008 \\
(0.049)\end{array}$ \\
\hline Eligible for DTF in current year (year 2) & $\begin{array}{r}0.011 \\
(0.013)\end{array}$ & $\begin{array}{r}-0.012 \\
(0.026)\end{array}$ & $\begin{array}{r}-0.004 \\
(0.023)\end{array}$ & $\begin{array}{r}0.004 \\
(0.049)\end{array}$ \\
\hline Eligible for DTF in prior year (year 1) & $\begin{array}{r}0.009 \\
(0.013)\end{array}$ & $\begin{array}{r}-0.030 \\
(0.027)\end{array}$ & $\begin{array}{r}-0.014 \\
(0.024)\end{array}$ & $\begin{array}{l}-0.003 \\
(0.050)\end{array}$ \\
\hline
\end{tabular}

Notes: The table shows regression discontinuity-based estimates of the effect of various income eligibility cut-offs on college attendance (at all) and attending four-year college (conditional on attending). The specification that includes current year and lagged income eligibility is employed: equation (7) in the text. Standard errors are in parentheses. Only estimates that employ the base case doughnut holes, which are unlikely to suffer from reverse causality bias, are shown. (See text for further information on the base case doughnut holes.) ***, **, or * indicates that an estimate is statistically significantly different from zero at the $0.01,0.05$, or 0.10 level.

Source: Authors' calculations based on de-identified tax data. 


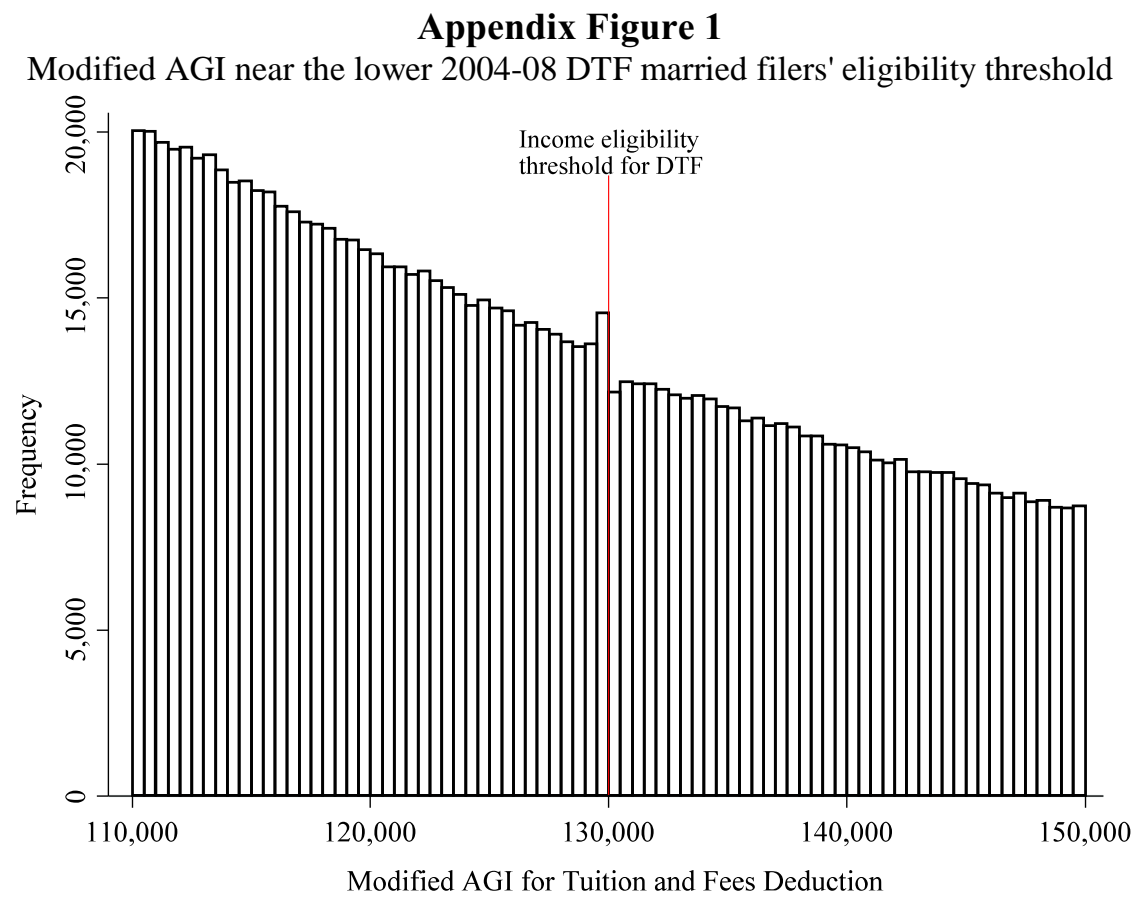

Notes: Figures are histograms of modified adjusted gross income in $\$ 500$ bins in year 1 (2002 and 2003 or 2004 through 2008) among married joint filers who had a child who would have graduated from high school in year 0 if he or she had progressed through secondary school on time. Source: De-identified tax data. 
Appendix Figure 2

Modified AGI near the upper 2004-08 DTF married filers' eligibility threshold

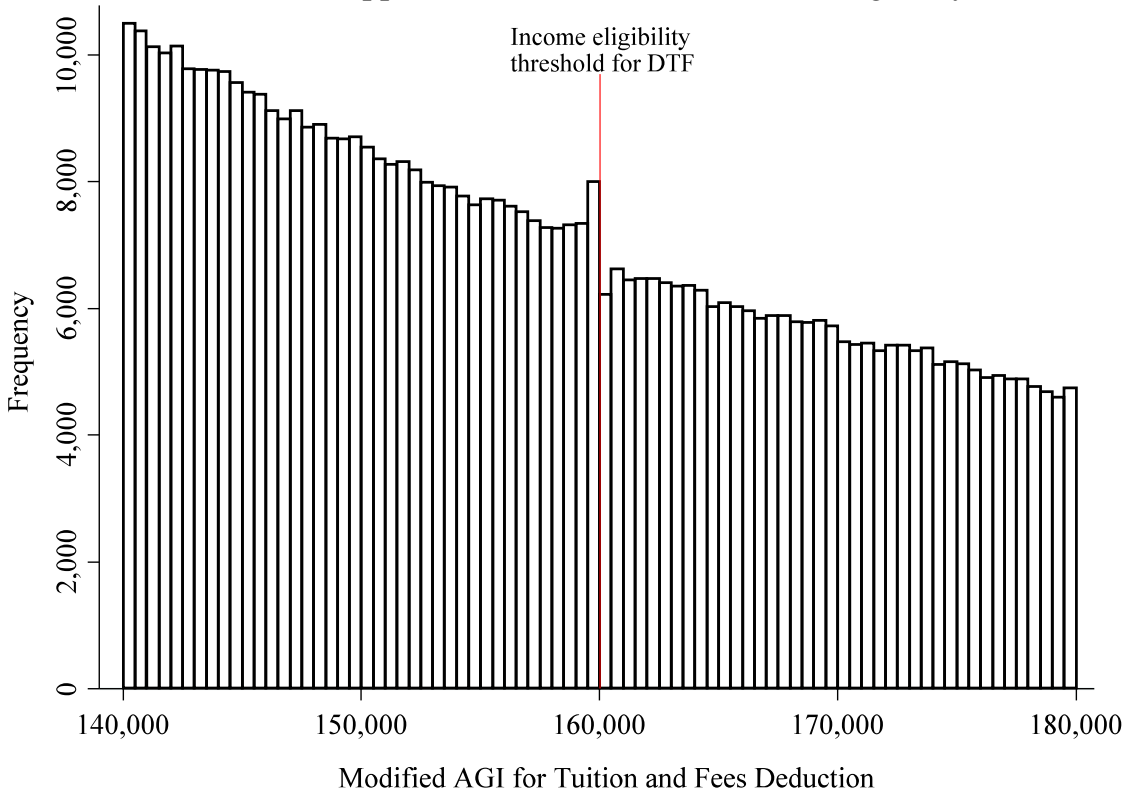

Appendix Figure 3

Modified AGI near the 2002-03 DTF single filers' eligibility threshold

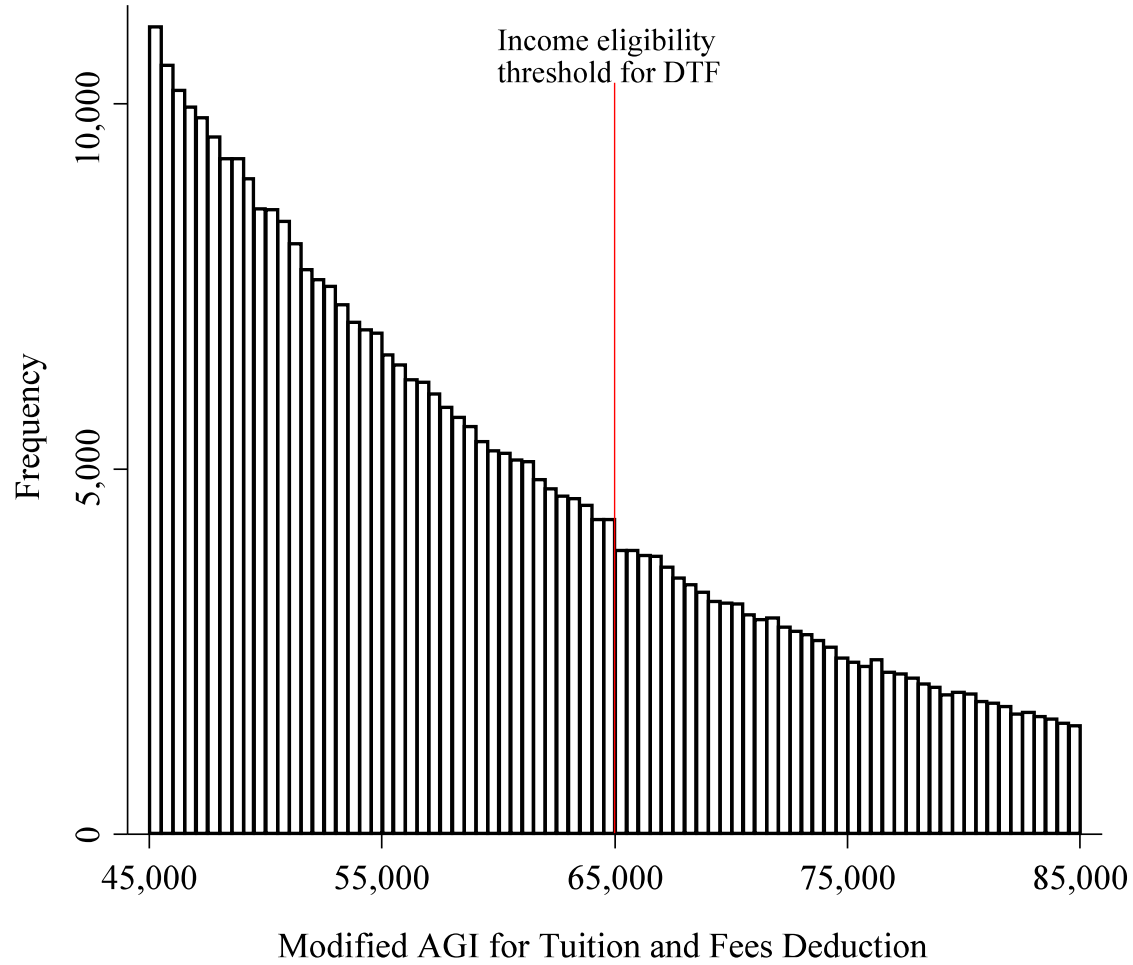

Notes: Figures are histograms of modified adjusted gross income in $\$ 500$ bins in year 1 (2002 and 2003 or 2004 through 2008) among married joint or single filers who had a child who would have graduated from high school in year 0 if he or she had progressed through secondary school on time. Source: de-identified tax data. 
Appendix Figure 4

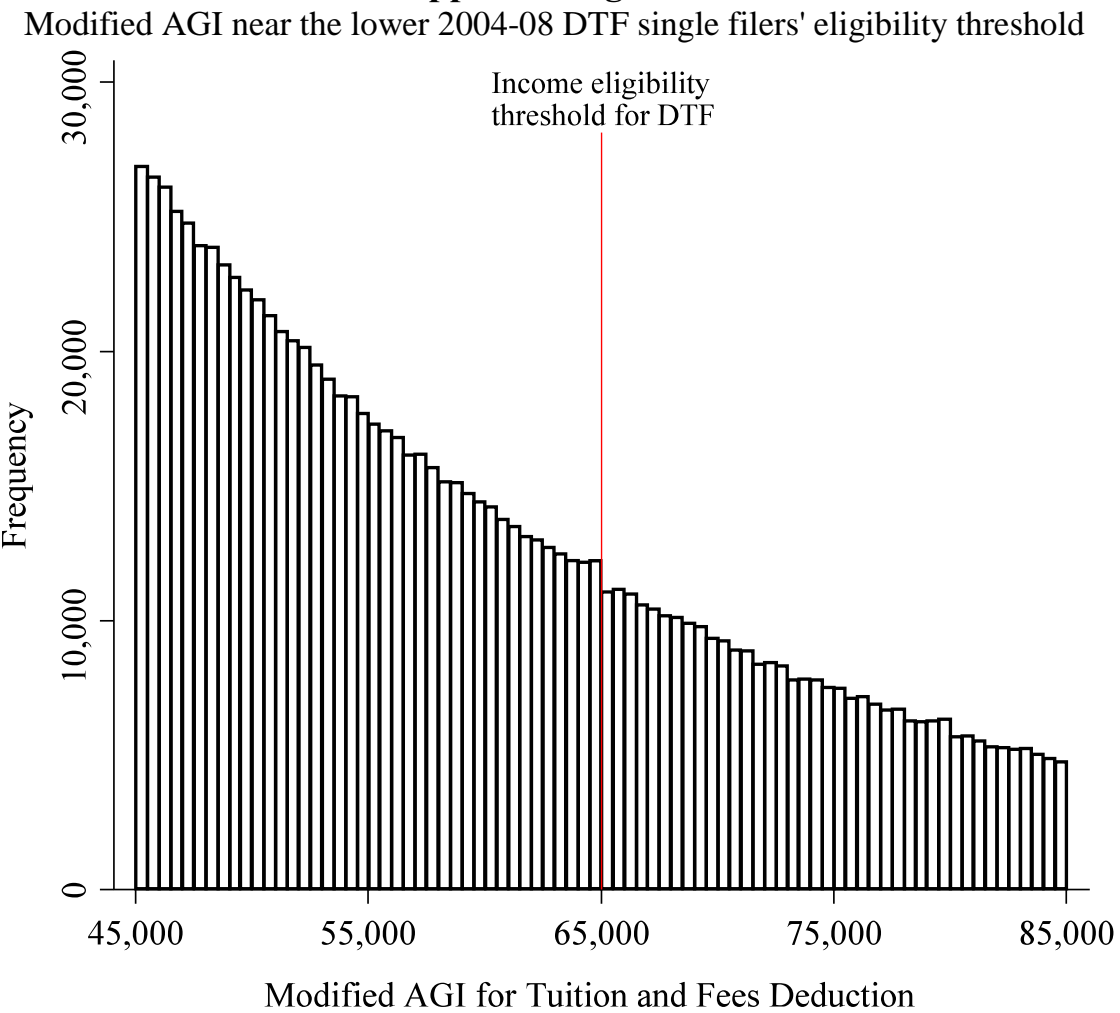

Appendix Figure 5

Modified AGI near the upper 2004-08 DTF single filers' eligibility threshold

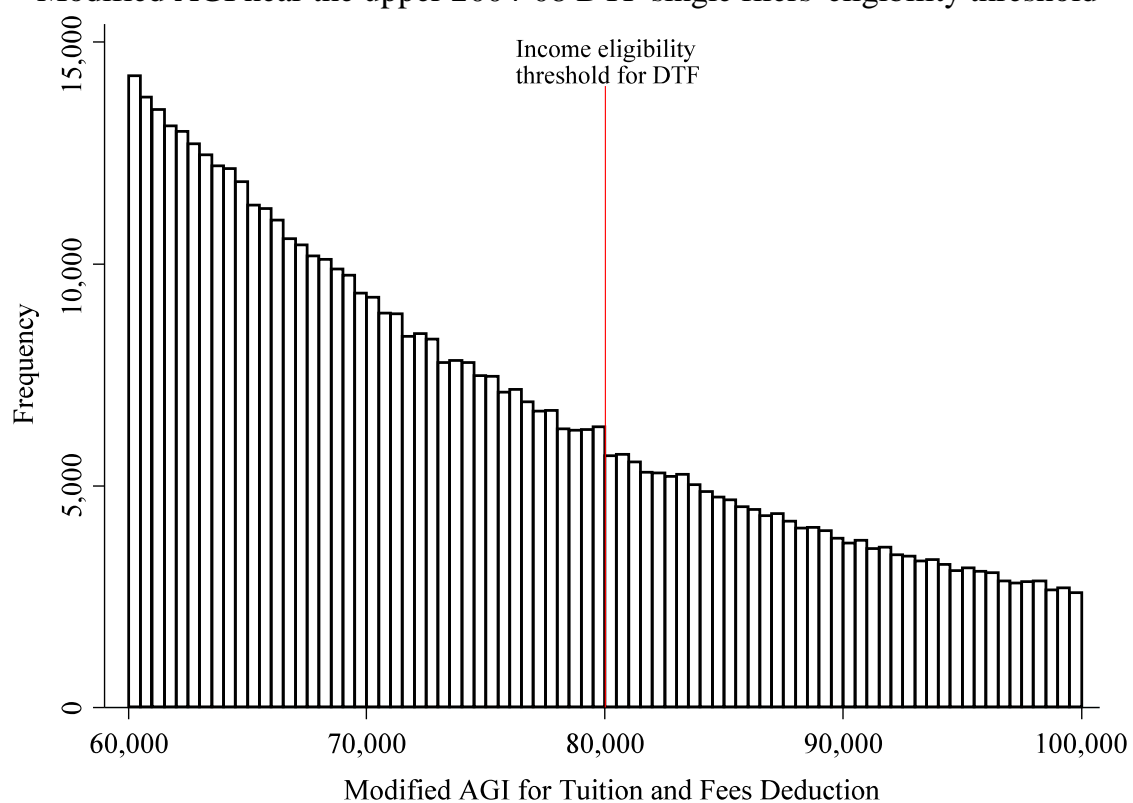

Notes: Figures are histograms of modified adjusted gross income in $\$ 500$ bins in year 1 (2004 through 2008) among single filers who had a child who would have graduated from high school in year 0 if he or she had progressed through secondary school on time. Source: de-identified tax data. 
Appendix Figure 6

(a) Taking DTF and modified AGI at lower 2004-08 married eligibility threshold

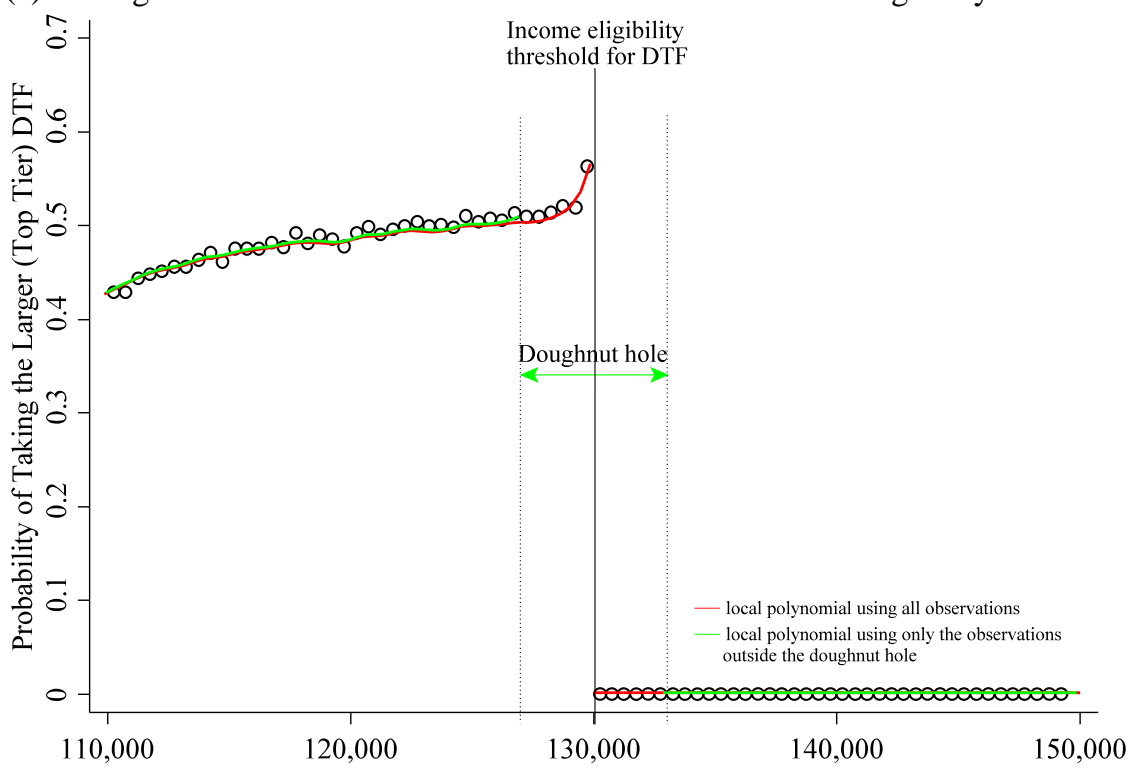

Modified AGI for Tuition and Fees Deduction

(b) Average DTF and modified AGI at lower 2004-08 married eligibility threshold

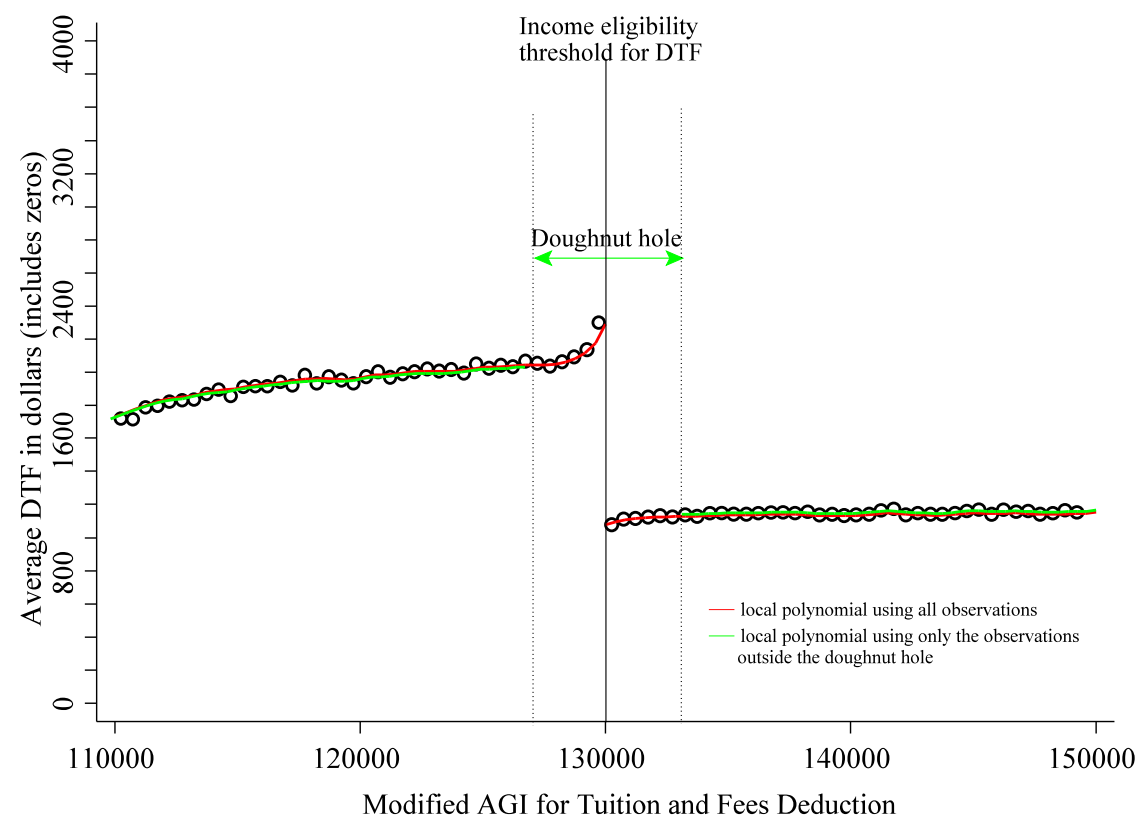

Notes: Figures show the probability of taking the DTF and average DTF in dollars as a function of modified adjusted gross income in year 1 (2004 through 2008) among married joint filers who had a child who would have graduated from high school in year 0 if he or she had progressed through secondary school on time. Average DTF includes zeros (non-takers). Each dot summarizes data in a $\$ 500$ interval. The figures also show smoothed values from gaussian kernel-weighted local polynomial regressions (degree 1, bandwidth 500) that include all observations or only those outside the doughnut hole. Source: de-identified tax data.

\section{Appendix Page 4}


Appendix Figure 7

(a) Taking DTF and modified AGI at upper 2004-08 married eligibility threshold

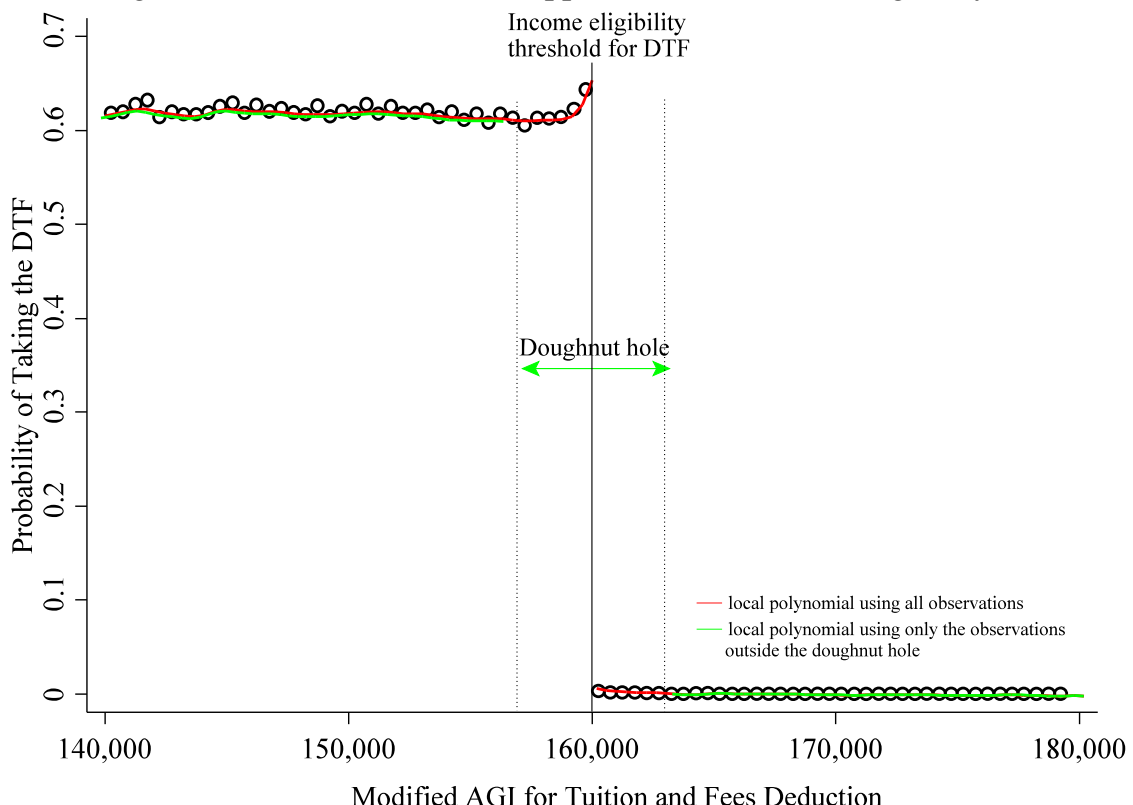

(b) Average DTF \& modified AGI at upper 2004-08 married eligibility threshold

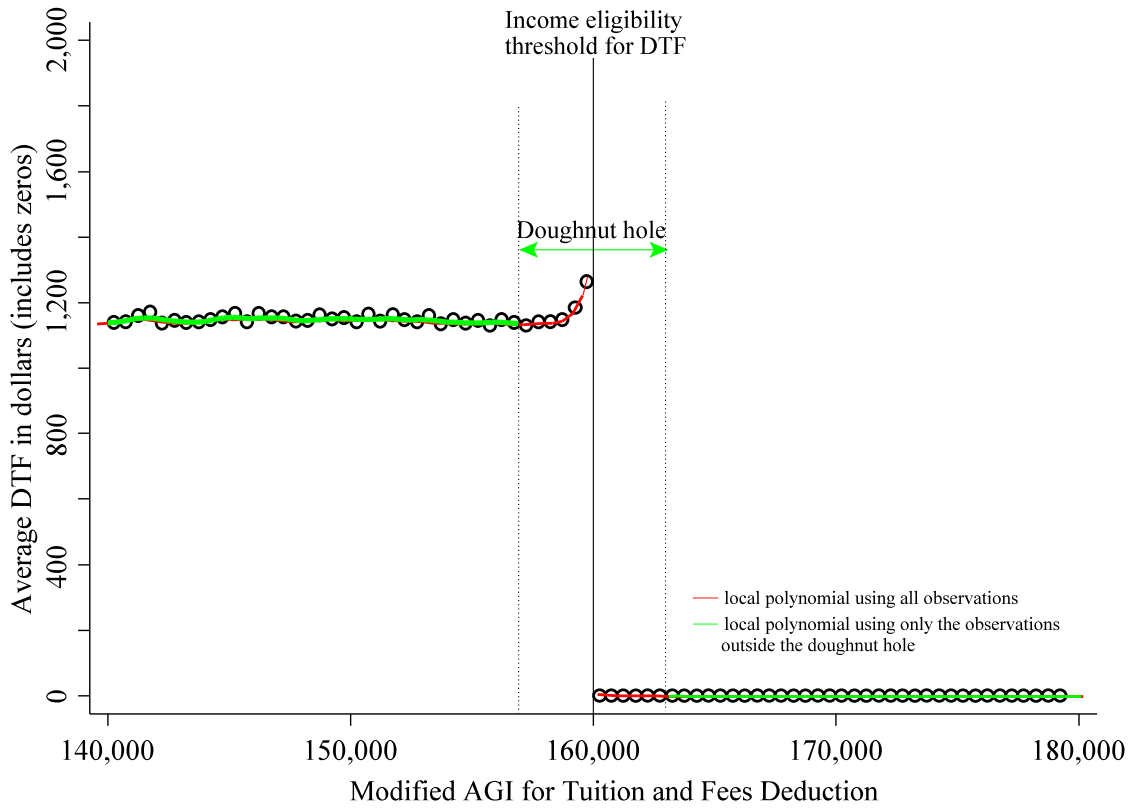

Notes: Figures show the probability of taking the DTF and average DTF in dollars as a function of modified adjusted gross income in year 1 (2004 through 2008) among married joint filers who had a child who would have graduated from high school in year 0 if he or she had progressed through secondary school on time. Average DTF includes zeros (non-takers). Each dot summarizes data in a $\$ 500$ interval. The figures also show smoothed values from gaussian kernel-weighted local polynomial regressions (degree 1, bandwidth 500) that include all observations or only those outside the doughnut hole. Source: de-identified tax data.

\section{Appendix Page 5}




\section{Appendix Figure 8}

(a) Taking DTF and modified AGI at 2002-03 single eligibility threshold

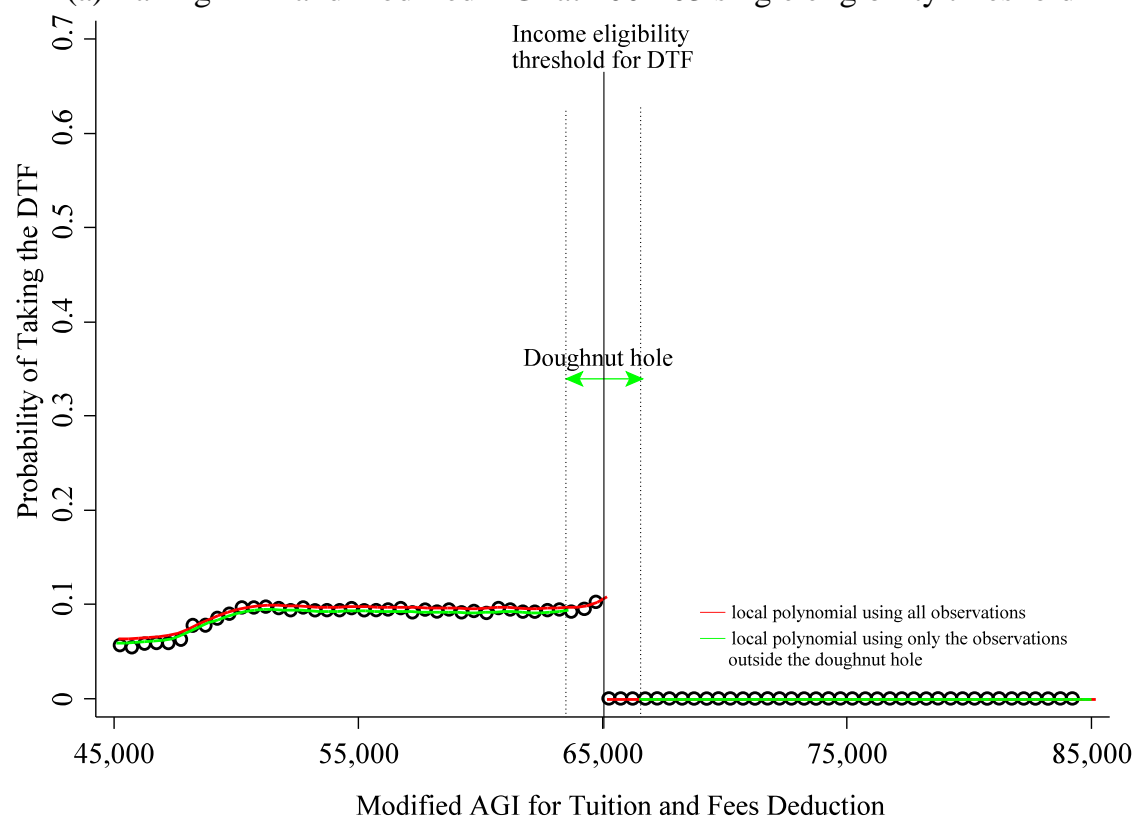

(b) Average DTF and modified AGI at 2002-03 single eligibility threshold

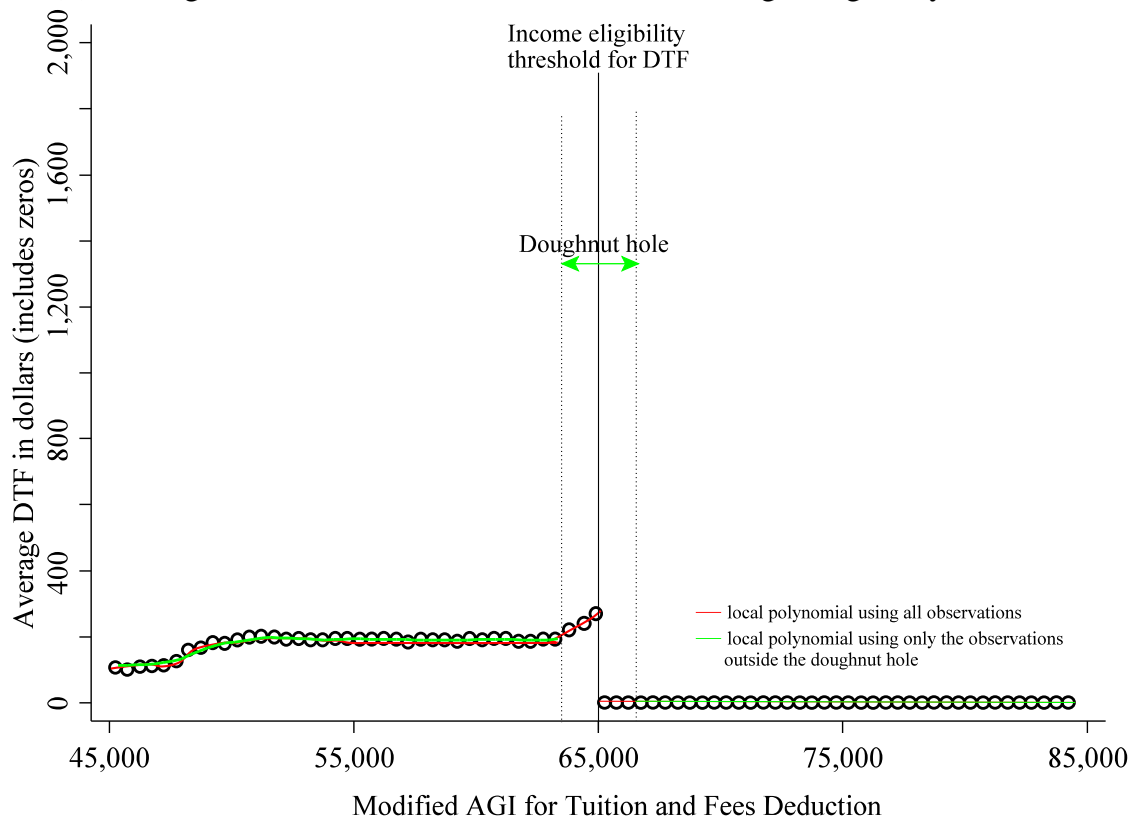

Notes: Figures show the probability of taking the DTF and average DTF in dollars as a function of modified adjusted gross income in year 1 (2002 and 2003) among single filers who had a child who would have graduated from high school in year 0 if he or she had progressed through secondary school on time. Average DTF includes zeros (non-takers). Each dot summarizes data in a $\$ 500$ interval. The figures also show smoothed values from gaussian kernel-weighted local polynomial regressions (degree 1, bandwidth 500) that include all observations or only those outside the doughnut hole. Source: de-identified tax data.

\section{Appendix Page 6}


Appendix Figure 9

(a) Taking DTF and modified AGI at lower 2004-08 single eligibility threshold 今.

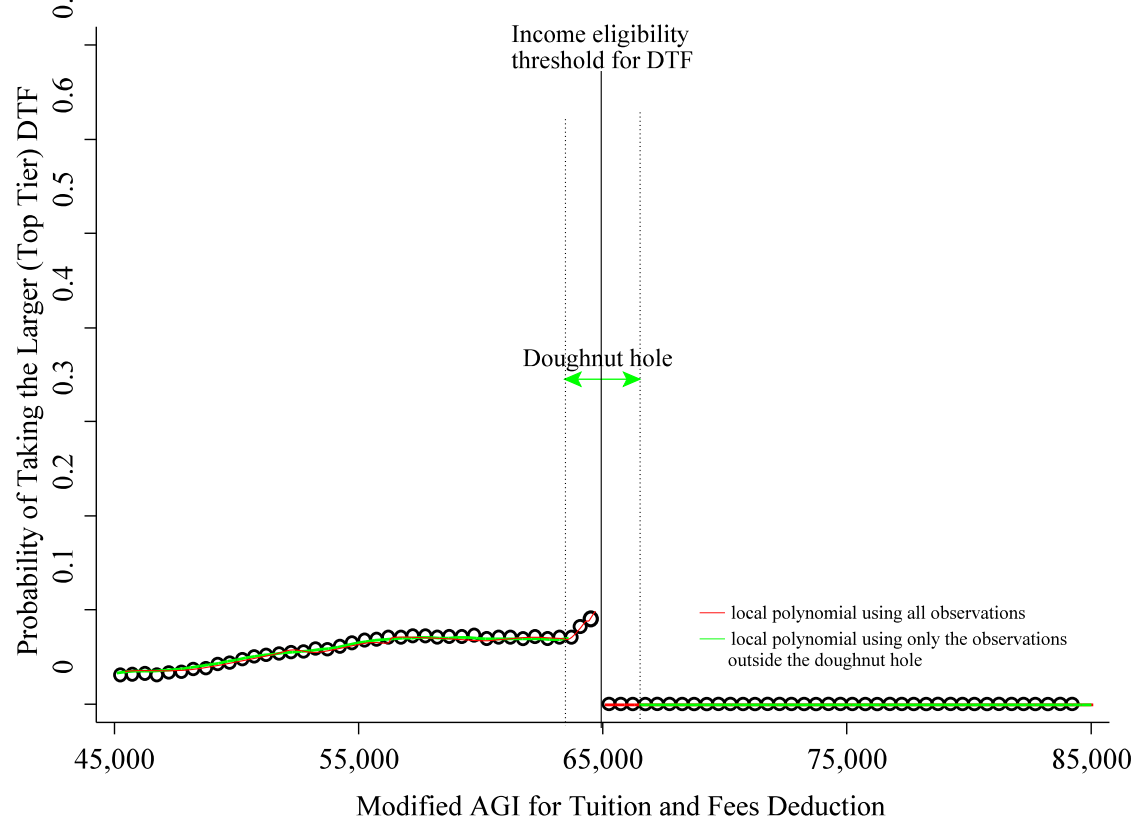

(b) Average DTF and modified AGI at lower 2004-08 single eligibility threshold

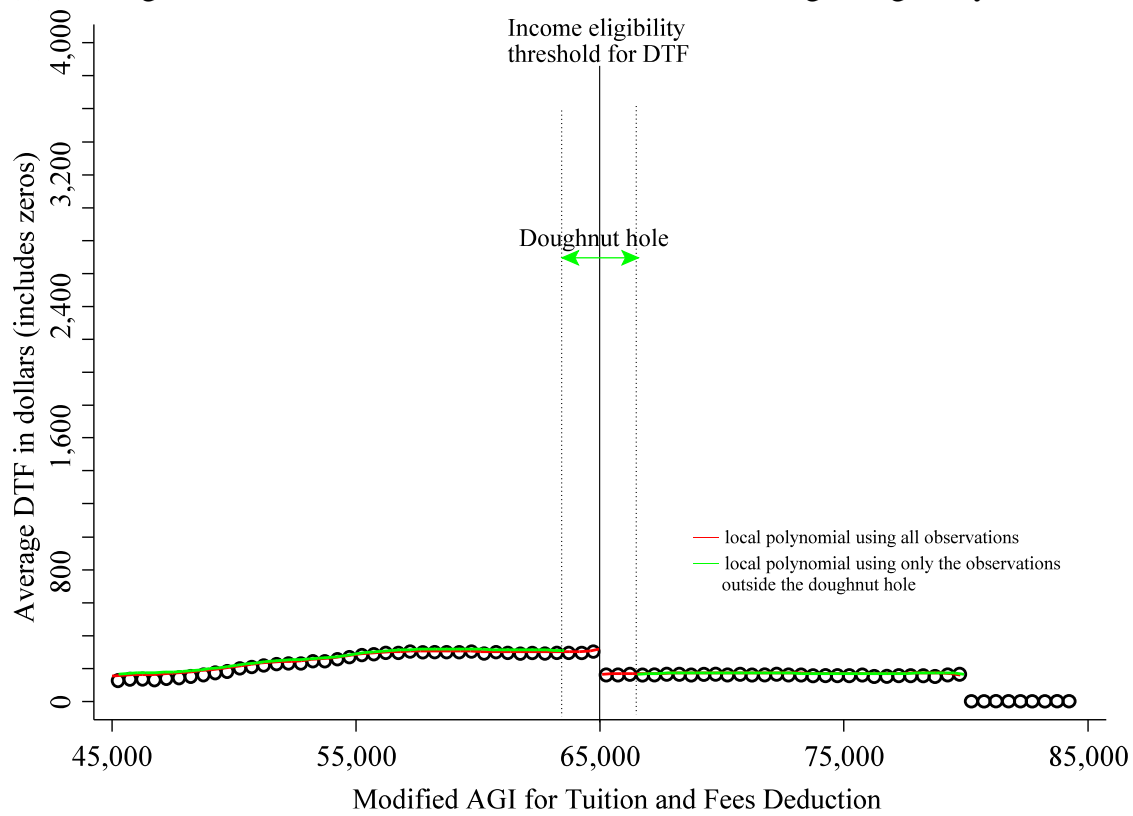

Notes: Figures show the probability of taking the DTF and average DTF in dollars as a function of modified adjusted gross income in year 1 (2004 through 2008) among single filers who had a child who would have graduated from high school in year 0 if he or she had progressed through secondary school on time. Average DTF includes zeros (non-takers). Each dot summarizes data in a $\$ 500$ interval. The figures also show smoothed values from gaussian kernel-weighted local polynomial regressions (degree 1, bandwidth 500) that include all observations or only those outside the doughnut hole. Source: de-identified tax data. 


\section{Appendix Figure 10}

(a) Taking DTF and modified AGI at upper 2004-08 single eligibility threshold

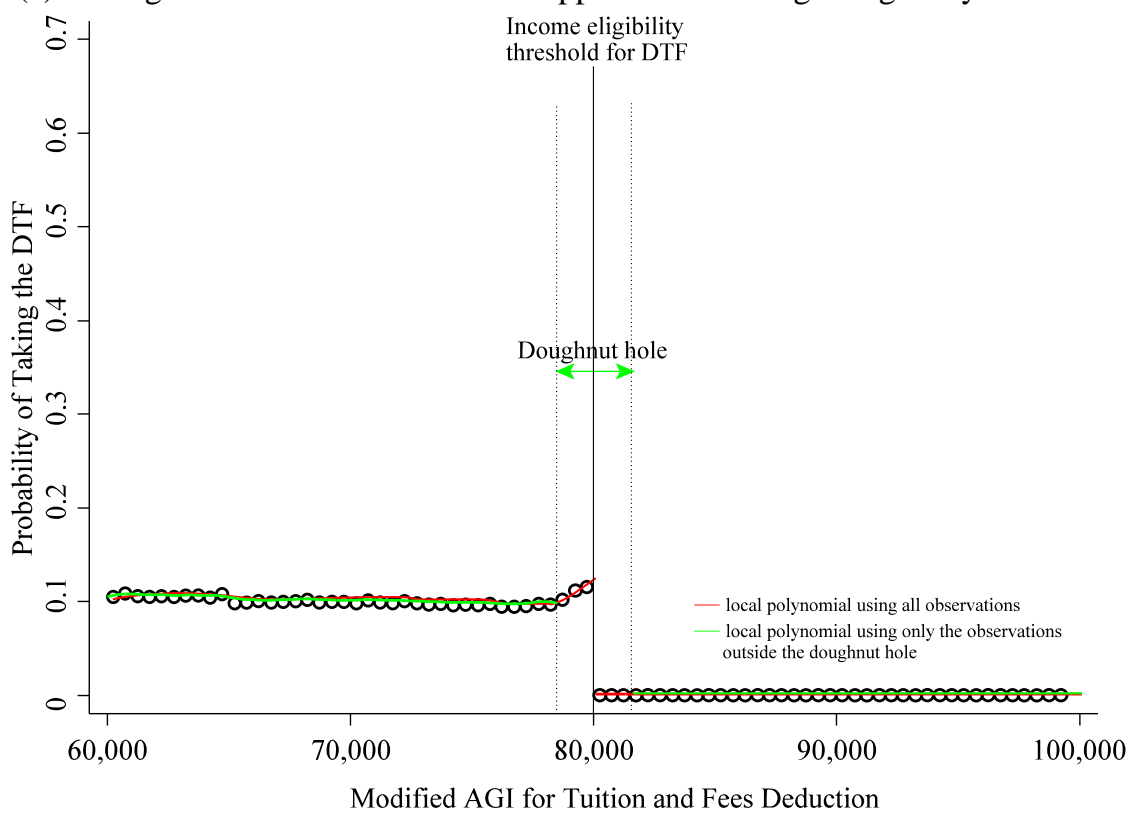

(b) Average DTF and modified AGI at upper 2004-08 single eligibility threshold

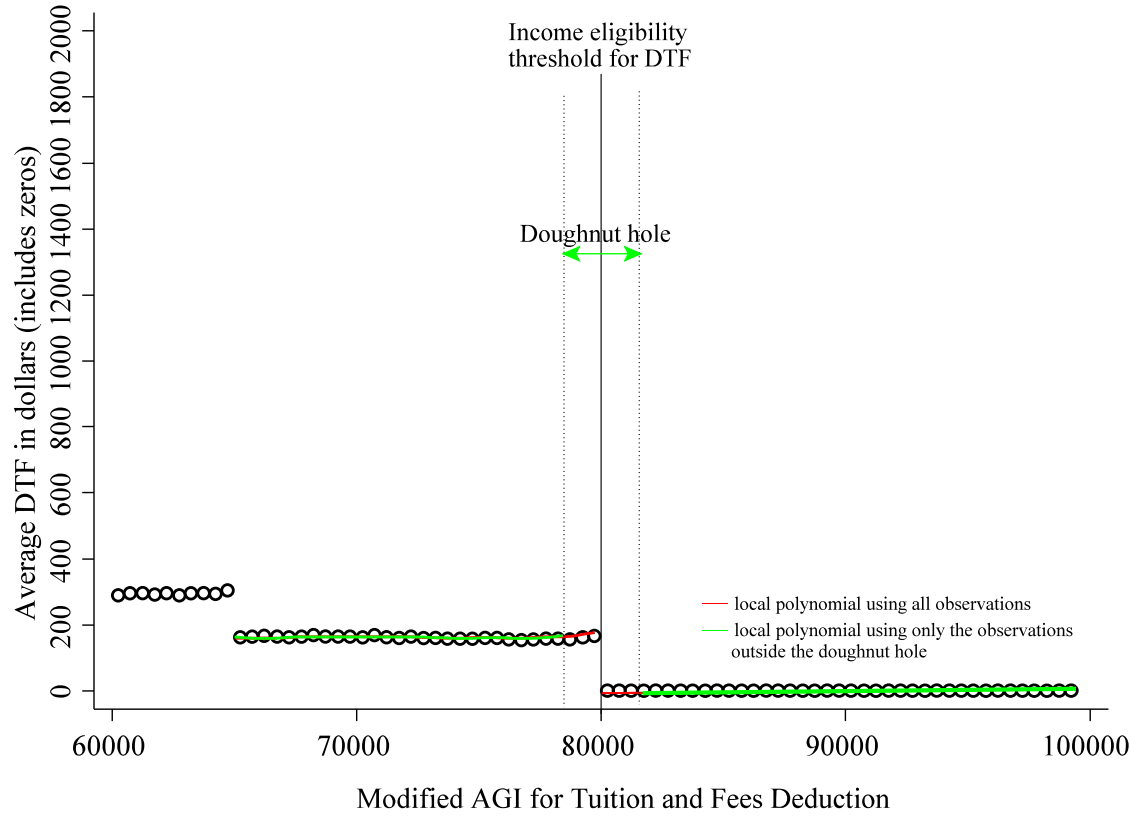

Notes: Figures show the probability of taking the DTF and average DTF in dollars as a function of modified adjusted gross income in year 1 (2004 through 2008) among single filers who had a child who would have graduated from high school in year 0 if he or she had progressed through secondary school on time. Average DTF includes zeros (non-takers). Each dot summarizes data in a $\$ 500$ interval. The figures also show smoothed values from gaussian kernel-weighted local polynomial regressions (degree 1, bandwidth 500) that include all observations or only those outside the doughnut hole. Source: de-identified tax data. 


\section{Appendix Figure 11}

(a) Attending college (at all) and modified AGI at the upper 2004-08 married eligibility threshold

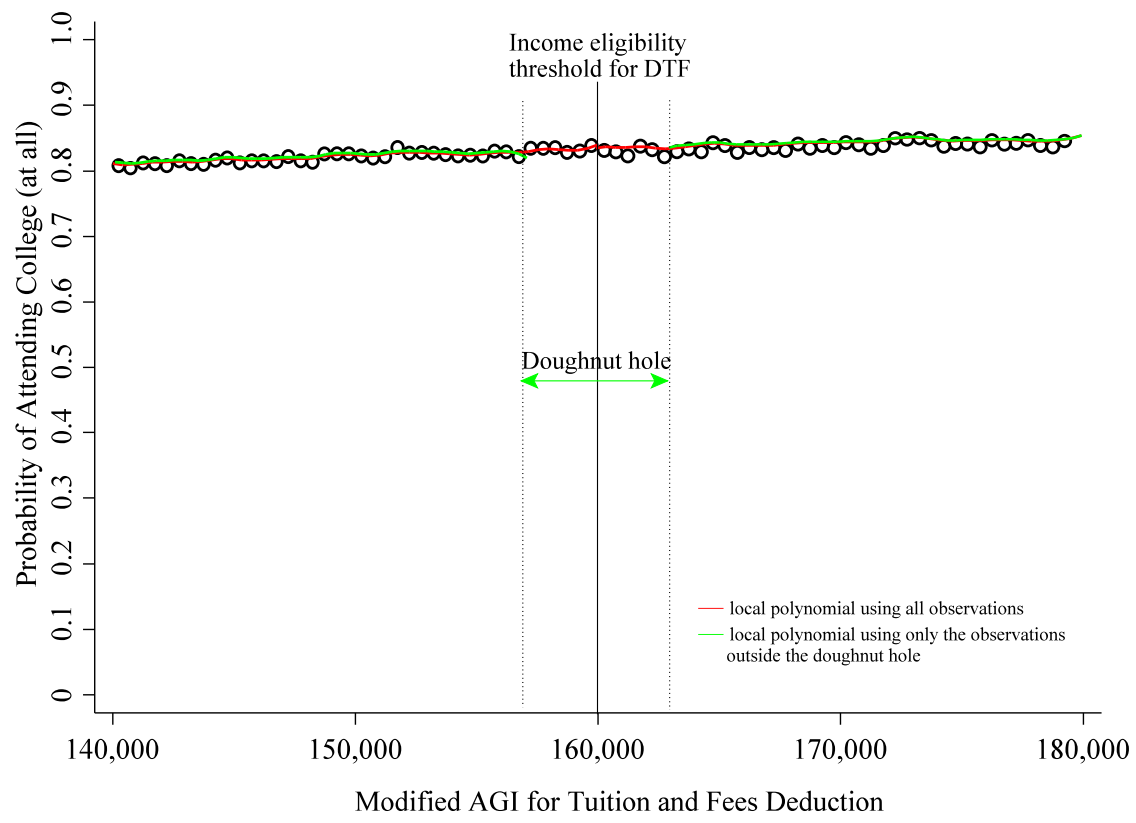

(b) Four-year college and modified AGI at the upper 2004-08 married eligibility threshold

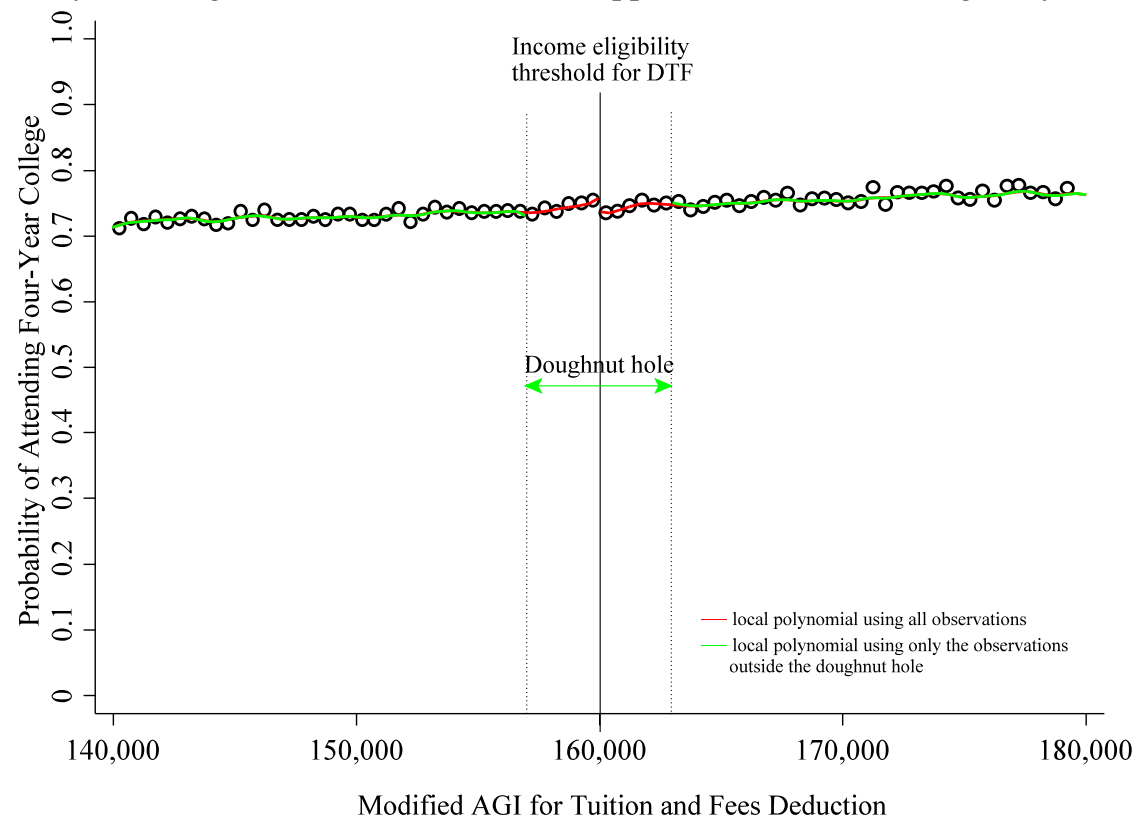

Notes: Figures show the probability of attending college (at all) and attending four-year college (conditional on attending at all) as a function of modified adjusted gross income in year 1 (2004 through 2008) among married joint filers who had a child who would have graduated from high school in year 0 if he or she had progressed through secondary school on time. Each dot summarizes data in a $\$ 500$ interval. The figures also show smoothed values from gaussian kernel-weighted local polynomial regressions (degree 1, bandwidth 500) that include all observations or only those outside the doughnut hole. Source: de-identified tax data. 


\section{Appendix Figure 12}

(a) Attending college and modified AGI at the 2002-03 single eligibility threshold

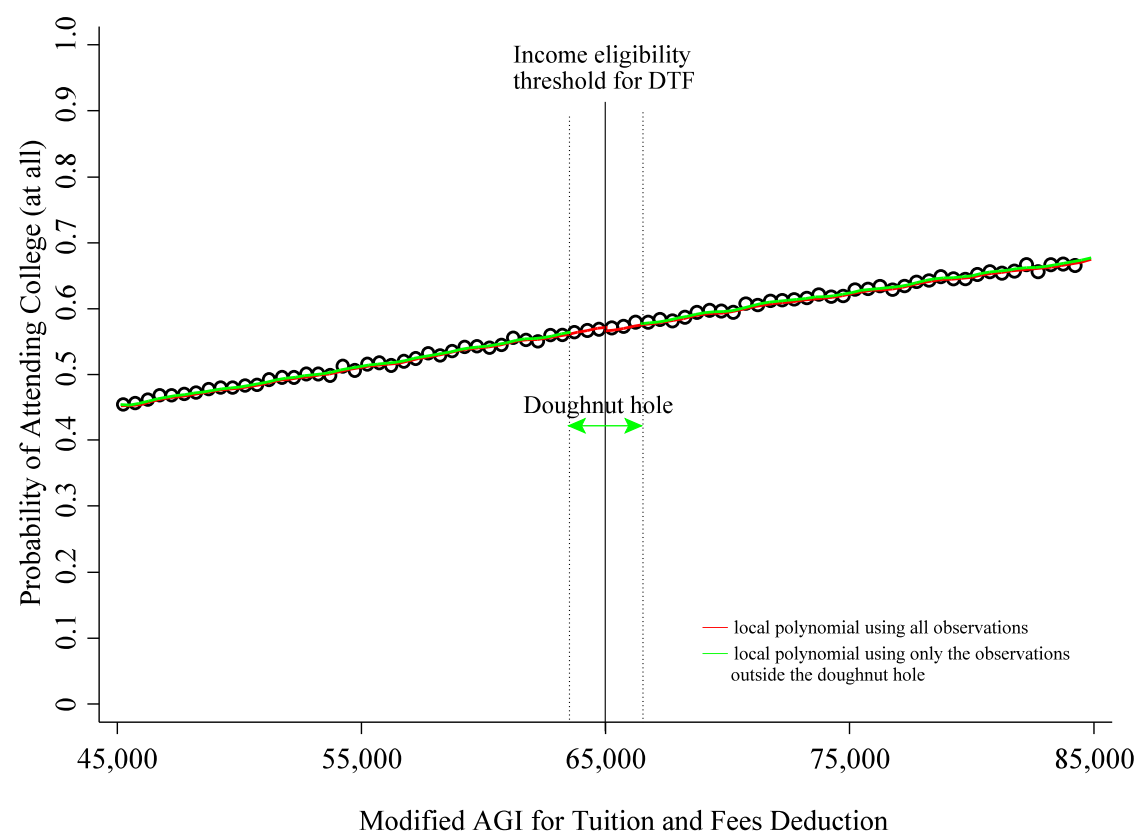

(b) Four-year college and modified AGI at the 2002-03 single eligibility threshold

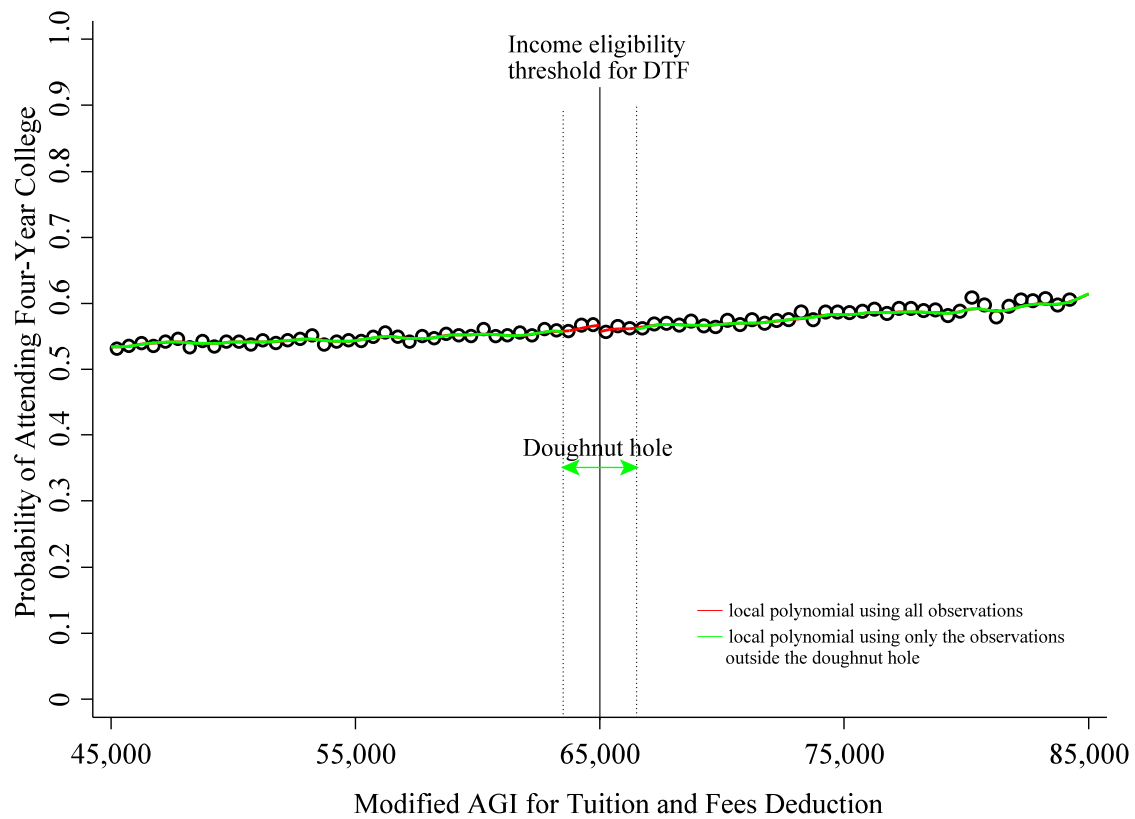

Notes: Figures show the probability of attending college (at all) and attending four-year college (conditional on attending at all) as a function of modified adjusted gross income in year 1 (2002 and 2003) among single filers who had a child who would have graduated from high school in year 0 if he or she had progressed through secondary school on time. Each dot summarizes data in a $\$ 500$ interval. The figures also show smoothed values from gaussian kernel-weighted local polynomial regressions (degree 1, bandwidth 500) that include all observations or only those outside the doughnut hole. Source: de-identified tax data. 


\section{Appendix Figure 13}

(a) Attending college and modified AGI at the lower 2004-08 single eligibility threshold

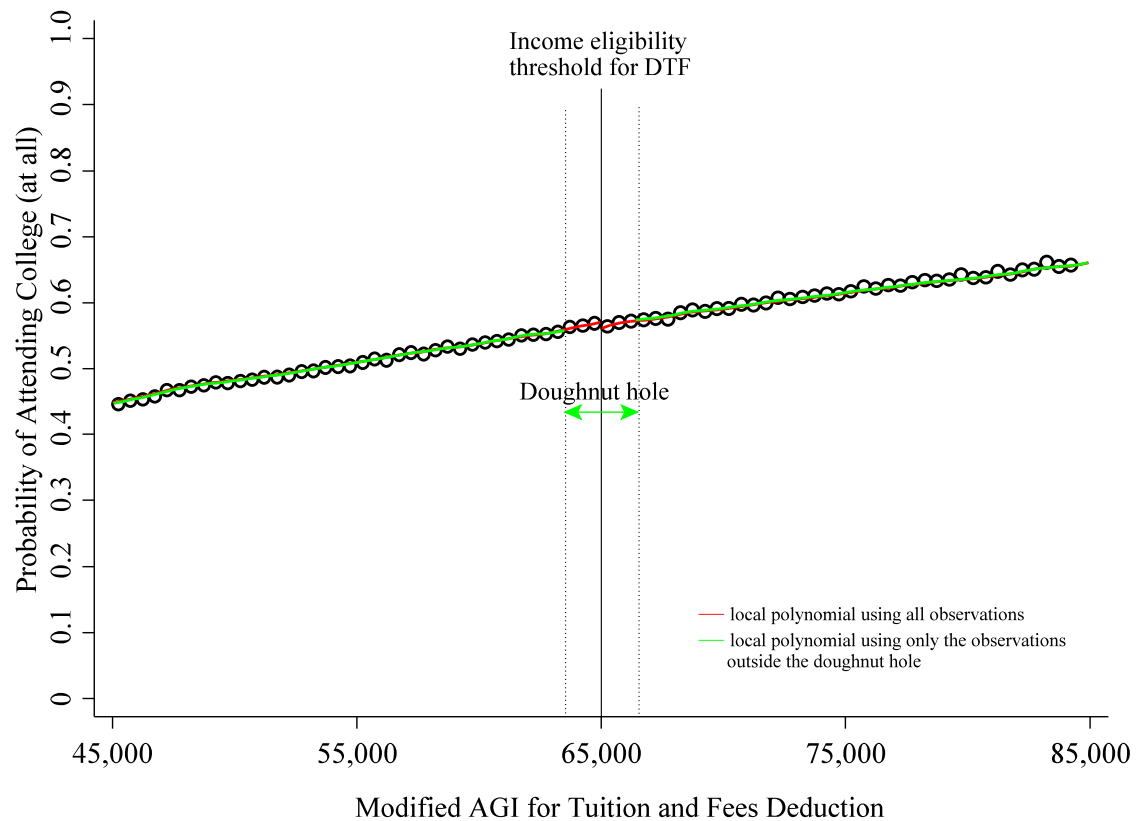

(b) Four-year college and modified AGI at the lower 2004-08 single eligibility threshold

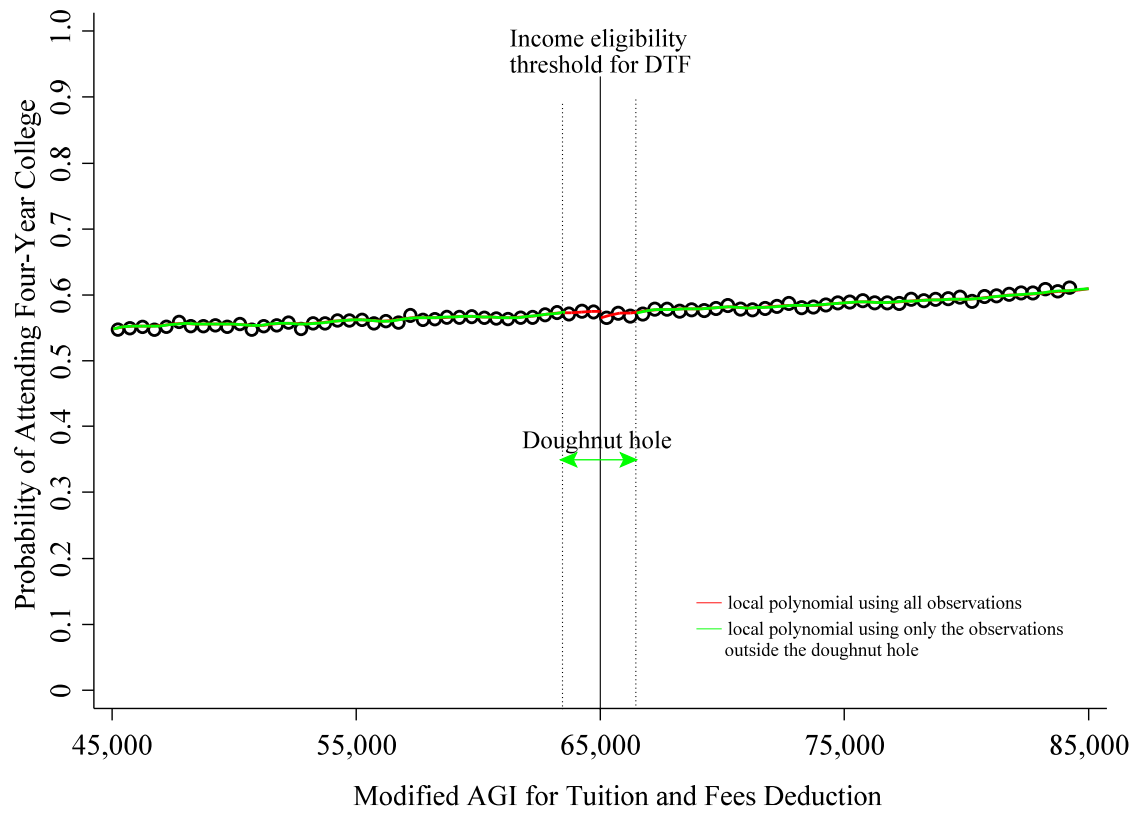

Notes: Figures show the probability of attending college (at all) and attending four-year college (conditional on attending at all) as a function of modified adjusted gross income in year 1 (2004 through 2008) among single filers who had a child who would have graduated from high school in year 0 if he or she had progressed through secondary school on time. Each dot summarizes data in a $\$ 500$ interval. The figures also show smoothed values from gaussian kernel-weighted local polynomial regressions (degree 1, bandwidth 500) that include all observations or only those outside the doughnut hole. Source: de-identified tax data. 


\section{Appendix Figure 14}

(a) Attending college and modified AGI at the upper 2004-08 single eligibility threshold

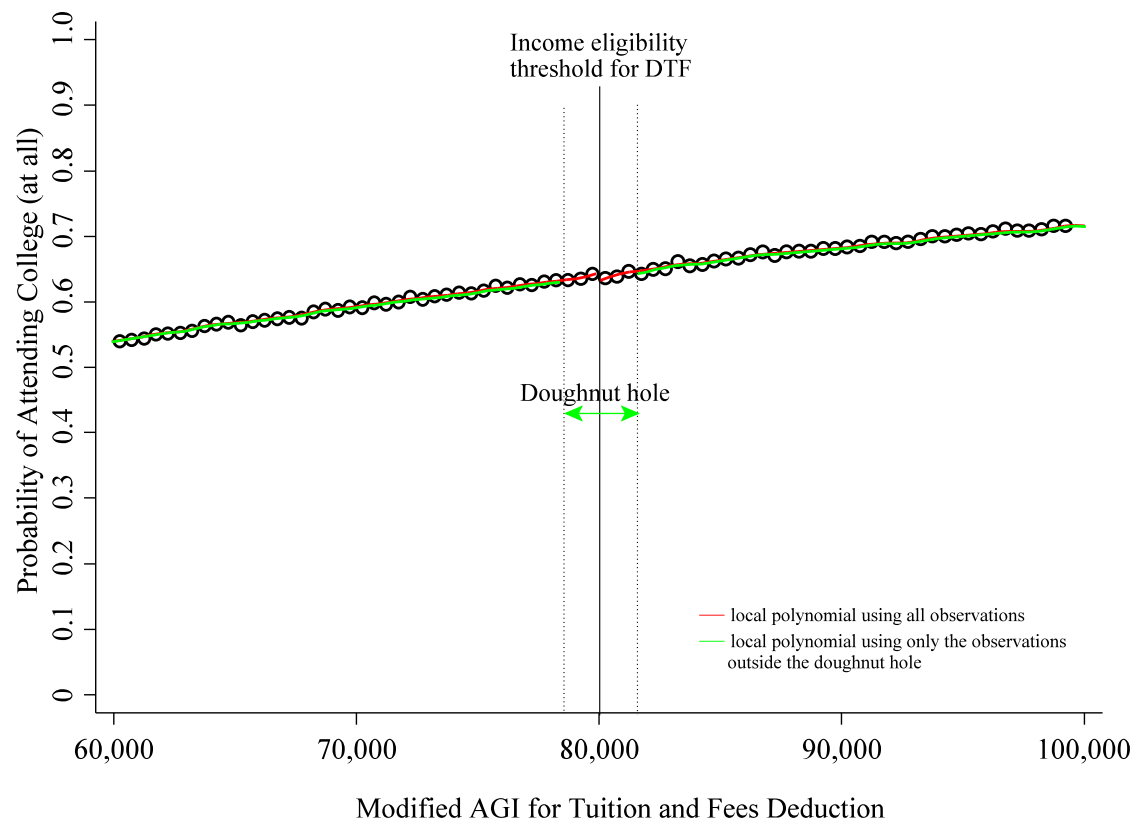

(b) Four-year college and modified AGI at the upper 2004-08 single eligibility threshold

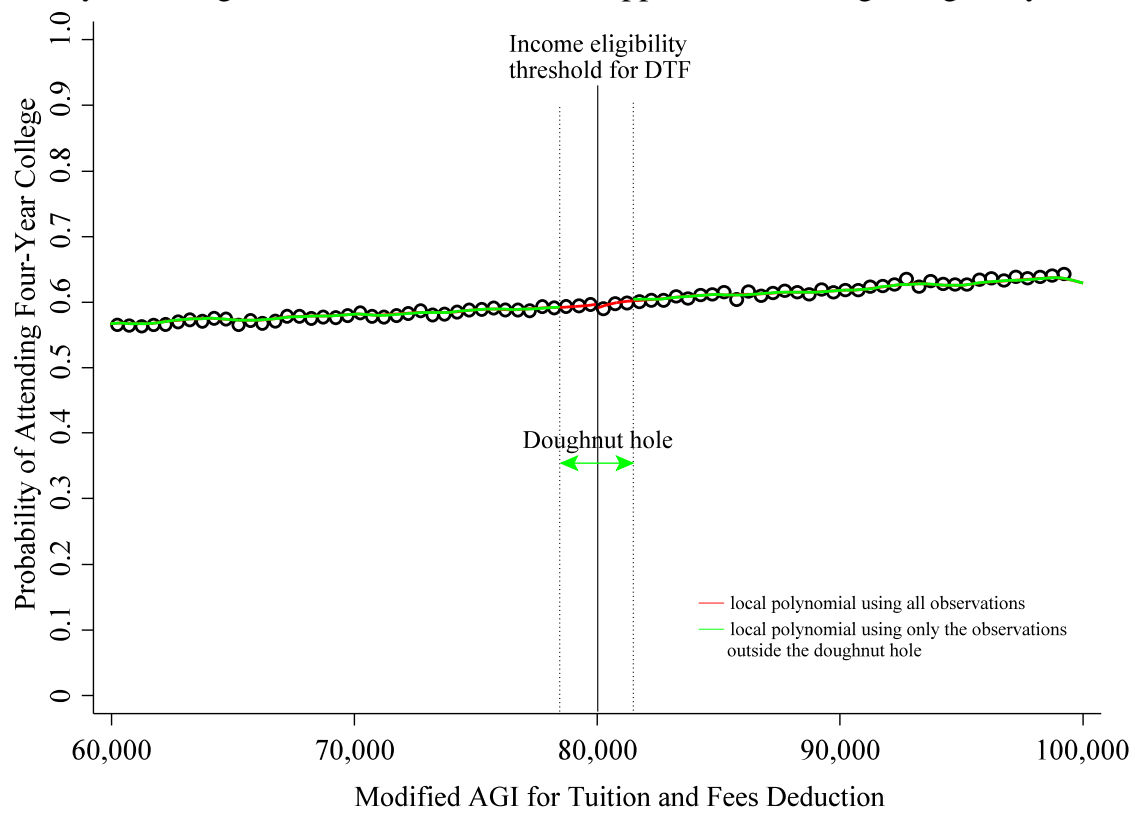

Notes: Figures show the probability of attending college (at all) and attending four-year college (conditional on attending at all) as a function of modified adjusted gross income in year 1 (2004 through 2008) among single filers who had a child who would have graduated from high school in year 0 if he or she had progressed through secondary school on time. Each dot summarizes data in a $\$ 500$ interval. The figures also show smoothed values from gaussian kernel-weighted local polynomial regressions (degree 1, bandwidth 500) that include all observations or only those outside the doughnut hole. Source: de-identified tax data. 
Appendix Table 1

College-Related Outcomes for the 2004 Cohort from Joint Filing Households all outcomes are for year 1 except as noted

\begin{tabular}{|c|c|c|c|c|c|}
\hline \multirow[b]{2}{*}{$\begin{array}{l}\text { Modified } \\
\text { Adjusted Gross } \\
\text { Income }\end{array}$} & \multirow[b]{2}{*}{$\begin{array}{l}\text { Number of } \\
\text { Households }\end{array}$} & \multicolumn{4}{|c|}{$\begin{array}{c}\text { All outcomes below for those who enroll in at least some postsecondary } \\
\text { education }\end{array}$} \\
\hline & & $\begin{array}{r}\text { Attend at } \\
\text { Least } \\
\text { Half-Time }\end{array}$ & $\begin{array}{r}\text { Grants and } \\
\text { Scholarships } \\
\text { Received }(\$)\end{array}$ & $\begin{array}{r}\text { "List" Tuition } \\
\text { and Fees }\end{array}$ & $\begin{array}{r}\text { Instructional } \\
\text { Spending Per } \\
\text { Student }\end{array}$ \\
\hline$\$ 0-25 \mathrm{k}$ & 223,253 & $86.4 \%$ & 6,397 & 6,314 & 6,033 \\
\hline$\$ 20-45 \mathrm{k}$ & 298,369 & $87.6 \%$ & 5,417 & 6,429 & 5,962 \\
\hline$\$ 45-55 \mathrm{k}$ & 174,107 & $88.8 \%$ & 4,269 & 6,590 & 5,974 \\
\hline$\$ 55-65 k$ & 183,033 & $89.8 \%$ & 3,850 & 6,796 & 6,003 \\
\hline$\$ 65-70 \mathrm{k}$ & 90,682 & $89.9 \%$ & 3,883 & 6,876 & 6,107 \\
\hline$\$ 70-75 \mathrm{k}$ & 88,492 & $90.4 \%$ & 3,418 & 7,032 & 6,122 \\
\hline$\$ 75-80 \mathrm{k}$ & 85,350 & $90.7 \%$ & 3,825 & 7,092 & 6,236 \\
\hline$\$ 80-90 \mathrm{k}$ & 155,395 & $90.9 \%$ & 3,534 & 7,319 & 6,365 \\
\hline$\$ 90-110 \mathrm{k}$ & 236,533 & $91.4 \%$ & 3,640 & 7,682 & 6,621 \\
\hline$\$ 110-120 \mathrm{k}$ & 83,681 & $91.6 \%$ & 3,574 & 8,174 & 7,012 \\
\hline$\$ 120-130 \mathrm{k}$ & 66,986 & $91.9 \%$ & 3,908 & 8,566 & 7,253 \\
\hline$\$ 130-140 \mathrm{k}$ & 51,764 & $91.9 \%$ & 4,171 & 8,842 & 7,525 \\
\hline$\$ 140-150 \mathrm{k}$ & 41,564 & $92.0 \%$ & 3,426 & 9,280 & 7,790 \\
\hline$\$ 150-160 \mathrm{k}$ & 33,680 & $92.4 \%$ & 3,228 & 9,627 & 8,064 \\
\hline$\$ 160-170 \mathrm{k}$ & 26,518 & $92.1 \%$ & 3,222 & 9,896 & 8,231 \\
\hline$\$ 170-180 \mathrm{k}$ & 21,843 & $92.4 \%$ & 3,354 & 9,996 & 8,410 \\
\hline$\$ 180 \mathrm{k}+$ & 189,049 & $92.1 \%$ & 2,637 & 12,765 & 10,212 \\
\hline
\end{tabular}

Notes: The 2004 cohort is the group of students who would be expected to graduate from high school in June 2004. A person is associated with a joint filing household if, when he is age 17 (and thus not independent) his household files jointly. We continue to associate each person with his age 17 household for the purpose of classification owing to the fact that, after age 17, filing status is endogenous to the person's enrollment in postsecondary school. Year 1 is the first full tax year after a person would be expected to graduate from high school if he started elementary school on time, according to his state's compulsory schooling laws, and progressed through school on schedule (with no retention in grade). Year 1 is the year in which people are most likely to be enrolled in postsecondary school. For on-time students, it corresponds to the spring of freshman year and fall of sophomore year in college.

Source: Authors' calculations based on de-identified tax data. 
Appendix Table 2

College-Related Outcomes for the 2004 Cohort from Single Filing Households all outcomes are for year 1 except as noted

\begin{tabular}{|c|c|c|c|c|c|c|c|c|c|c|}
\hline \multirow[b]{2}{*}{$\begin{array}{l}\text { Modified } \\
\text { Adjusted } \\
\text { Gross } \\
\text { Income }\end{array}$} & \multirow[b]{2}{*}{$\begin{array}{r}\text { Number } \\
\text { of } \\
\text { House- } \\
\text { holds }\end{array}$} & \multirow[b]{2}{*}{$\begin{array}{r}\text { Attend } \\
\text { Postse- } \\
\text { condary } \\
\text { at All }\end{array}$} & \multicolumn{8}{|c|}{ All outcomes below are conditional on some postsecondary attendance } \\
\hline & & & $\begin{array}{r}\text { Attend } \\
\text { at Least } \\
\text { Half- } \\
\text { Time }\end{array}$ & $\begin{array}{r}\text { Attend } \\
\text { a Four- } \\
\text { Year } \\
\text { College }\end{array}$ & $\begin{array}{r}\text { Tuition } \\
\text { and } \\
\text { Fees } \\
\text { Paid } \\
(\$)\end{array}$ & $\begin{array}{r}\text { Grants } \\
\text { and } \\
\text { Schol- } \\
\text { arships } \\
\text { Re- } \\
\text { ceived } \\
(\$)\end{array}$ & $\begin{array}{r}\text { "List" } \\
\text { Tuition } \\
\text { and } \\
\text { Fees } \\
(\$)\end{array}$ & $\begin{array}{r}\text { Instruc- } \\
\text { tional } \\
\text { Spend } \\
\text { ing Per } \\
\text { Student } \\
(\$)\end{array}$ & $\begin{array}{r}\text { Core } \\
\text { Educa- } \\
\text { tional } \\
\text { Re- } \\
\text { sources } \\
(\$)\end{array}$ & $\begin{array}{r}\text { Interest } \\
\text { Paid on } \\
\text { Student } \\
\text { Loans } \\
\text { through } \\
\text { year } 7 \\
(\$)\end{array}$ \\
\hline$\$ 0-25 \mathrm{k}$ & 535,248 & $24.8 \%$ & $84.8 \%$ & $53.1 \%$ & 6,878 & 5,211 & 5,958 & 5,537 & 13,499 & 715 \\
\hline$\$ 25-45 \mathrm{k}$ & 371,594 & $35.4 \%$ & $86.6 \%$ & $55.0 \%$ & 7,247 & 4,738 & 6,337 & 5,740 & 14,007 & 956 \\
\hline$\$ 45-55 \mathrm{k}$ & 98,366 & $46.0 \%$ & $88.5 \%$ & $56.4 \%$ & 7,939 & 4,226 & 6,778 & 6,167 & 15,055 & 1,136 \\
\hline$\$ 55-65 \mathrm{k}$ & 63,631 & $52.1 \%$ & $88.8 \%$ & $57.6 \%$ & 8,659 & 4,317 & 7,083 & 6,217 & 15,238 & 1,202 \\
\hline$\$ 65-70 \mathrm{k}$ & 22,487 & $56.0 \%$ & $89.2 \%$ & $58.5 \%$ & 9,512 & 4,354 & 7,313 & 6,388 & 15,701 & 1,219 \\
\hline$\$ 70-75 \mathrm{k}$ & 17,933 & $58.7 \%$ & $89.0 \%$ & $57.9 \%$ & 10,874 & 3,497 & 7,210 & 6,542 & 15,965 & 1,198 \\
\hline$\$ 75-80 \mathrm{k}$ & 14,153 & $60.2 \%$ & $89.7 \%$ & $60.1 \%$ & 11,513 & 5 & 7,645 & 6,692 & 16,369 & 1,209 \\
\hline$\$ 80-90 k$ & 19,903 & $62.4 \%$ & $89.7 \%$ & $61.8 \%$ & 11,124 & 4,596 & 7,930 & 6,934 & 16,946 & 1,270 \\
\hline$\$ 90-110 \mathrm{k}$ & 21,514 & $66.5 \%$ & $89.4 \%$ & $62.9 \%$ & 14,514 & 4,547 & 8,211 & 7,285 & 17,860 & 1,208 \\
\hline$\$ 110-120 \mathrm{k}$ & 5,963 & $69.6 \%$ & $90.5 \%$ & $65.4 \%$ & 14,998 & 4,959 & 8,855 & 7,425 & 18,194 & 1,078 \\
\hline$\$ 120-130 \mathrm{k}$ & 4,320 & 72 & $90.2 \%$ & 65 & 15,190 & 3 , & 0,0 & 7,670 & 18,866 & 1,063 \\
\hline$\$ 130-140 \mathrm{k}$ & 3,253 & $72.7 \%$ & $90.6 \%$ & $69.3 \%$ & 15,279 & 5,409 & 9,485 & 8,133 & 19,861 & 1,148 \\
\hline$\$ 140-150 \mathrm{k}$ & 2,411 & $74.1 \%$ & $91.0 \%$ & $69.2 \%$ & 15,703 & 4,150 & 9,714 & 8,072 & 19,800 & 1,009 \\
\hline$\$ 150-160 \mathrm{k}$ & 2,091 & $74.2 \%$ & $90.9 \%$ & $69.7 \%$ & 15,853 & 2,556 & 9,480 & 8,043 & 19,747 & 1,032 \\
\hline$\$ 160-170 \mathrm{k}$ & 1,571 & $75.9 \%$ & $91.6 \%$ & $71.2 \%$ & 16,825 & 3,957 & 9,643 & 8,326 & 20,344 & 938 \\
\hline$\$ 170-180 \mathrm{k}$ & 1,337 & $74.7 \%$ & $92.7 \%$ & $70.5 \%$ & 19,536 & 3,463 & 10,273 & 8,503 & 20,803 & 981 \\
\hline$\$ 180 \mathrm{k}+$ & 12,502 & $79.5 \%$ & $91.2 \%$ & $77.0 \%$ & 19,205 & 2,394 & 11,785 & 9,642 & 23,606 & 647 \\
\hline
\end{tabular}

Notes: The 2004 cohort is the group of students who would be expected to graduate from high school in June 2004. A person is associated with a joint filing household if, when he is age 17 (and thus not independent) his household files jointly. We continue to associate each person with his age 17 household for the purpose of classification owing to the fact that, after age 17, filing status is endogenous to the person's enrollment in postsecondary school. Year 1 is the first full tax year after a person would be expected to graduate from high school if he started elementary school on time, according to his state's compulsory schooling laws, and progressed through school on schedule (with no retention in grade). Year 1 is the year in which people are most likely to be enrolled in postsecondary school. For on-time students, it corresponds to the spring of freshman year and fall of sophomore year in college.

Source: Authors' calculations based on de-identified tax data. 
Appendix Table 3

Effect of the DTF Threshold on Deduction Take-up in Year 1

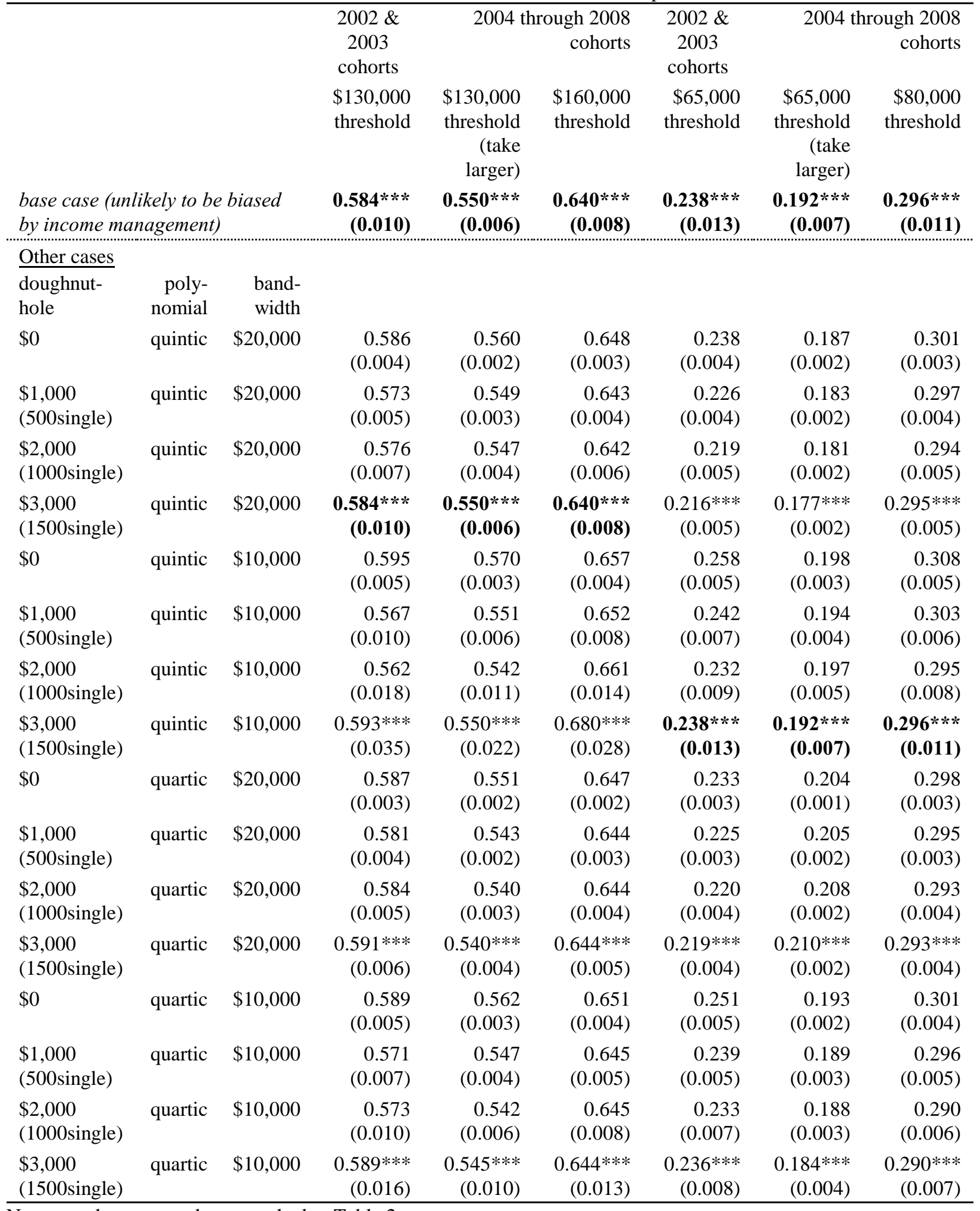

Notes are the same as those attached to Table 2. 
Appendix Table 4

Effect of the DTF Threshold on the Deduction Amount in Year 1 (unconditional on taking it up)

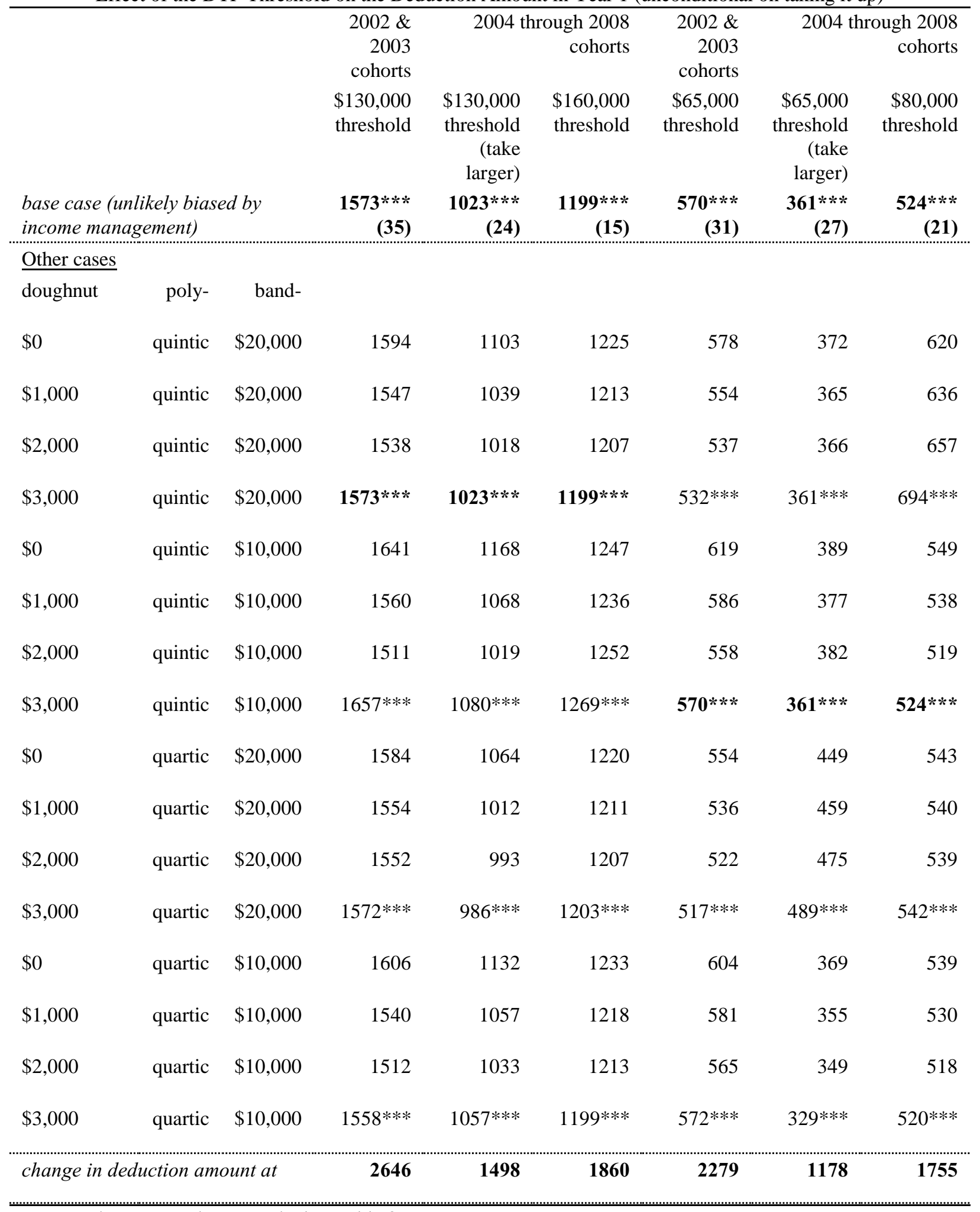

Notes are the same as those attached to Table 3.

Appendix Page 16 
Appendix Table 5

Effect of the DTF Threshold on College Attendance in Year 1

\begin{tabular}{|c|c|c|c|c|c|c|c|c|}
\hline & \multicolumn{3}{|c|}{ joint filing households } & \multicolumn{3}{|c|}{ single filing households } \\
\hline & & & $\begin{array}{r}2002 \& \\
2003\end{array}$ & \multicolumn{2}{|c|}{$\begin{array}{r}2004 \text { through } 2008 \\
\text { cohorts }\end{array}$} & $\begin{array}{r}2002 \& \\
2003\end{array}$ & \multicolumn{2}{|c|}{$\begin{array}{r}2004 \text { through } 2008 \\
\text { cohorts }\end{array}$} \\
\hline & & & $\begin{array}{l}\$ 130,000 \\
\text { threshold }\end{array}$ & $\begin{array}{l}\$ 130,000 \\
\text { threshold }\end{array}$ & $\begin{array}{l}\$ 160,000 \\
\text { threshold }\end{array}$ & $\begin{array}{r}\$ 65,000 \\
\text { threshold }\end{array}$ & $\begin{array}{r}\$ 65,000 \\
\text { threshold }\end{array}$ & $\begin{array}{r}\$ 80,000 \\
\text { threshold }\end{array}$ \\
\hline \multicolumn{3}{|c|}{$\begin{array}{l}\text { base case (unlikely to be biased by } \\
\text { income management) }\end{array}$} & $\begin{array}{r}-0.007 \\
(0.009)\end{array}$ & $\begin{array}{r}-0.003 \\
(0.006)\end{array}$ & $\begin{array}{r}0.000 \\
(0.008)\end{array}$ & $\begin{array}{r}-0.005 \\
(0.007)\end{array}$ & $\begin{array}{r}0.005 \\
(0.004)\end{array}$ & $\begin{array}{r}-0.000 \\
(0.006)\end{array}$ \\
\hline \multicolumn{9}{|l|}{ Other cases } \\
\hline $\begin{array}{l}\text { doughnut } \\
\text { hole }\end{array}$ & $\begin{array}{r}\text { polyno } \\
\text { mial }\end{array}$ & $\begin{array}{l}\text { band- } \\
\text { width }\end{array}$ & & & & & & \\
\hline$\$ 0$ & quintic & $\$ 20,000$ & $\begin{array}{r}0.019 \\
(0.004)\end{array}$ & $\begin{array}{r}0.012 \\
(0.003)\end{array}$ & $\begin{array}{r}0.007 \\
(0.003)\end{array}$ & $\begin{array}{r}0.005 \\
(0.005)\end{array}$ & $\begin{array}{r}0.012 \\
(0.003)\end{array}$ & $\begin{array}{r}0.005 \\
(0.005)\end{array}$ \\
\hline $\begin{array}{l}\$ 1,000 \\
(500 \text { single })\end{array}$ & quintic & $\$ 20,000$ & $\begin{array}{r}0.005 \\
(0.005)\end{array}$ & $\begin{array}{r}0.003 \\
(0.003)\end{array}$ & $\begin{array}{r}0.007 \\
(0.004)\end{array}$ & $\begin{array}{r}-0.002 \\
(0.006)\end{array}$ & $\begin{array}{r}0.009 \\
(0.004)\end{array}$ & $\begin{array}{r}0.001 \\
(0.005)\end{array}$ \\
\hline $\begin{array}{l}\$ 2,000 \\
(1000 \text { single })\end{array}$ & quintic & $\$ 20,000$ & $\begin{array}{r}0.005 \\
(0.007)\end{array}$ & $\begin{array}{r}0.001 \\
(0.004)\end{array}$ & $\begin{array}{r}0.009 \\
(0.006)\end{array}$ & $\begin{array}{r}-0.005 \\
(0.007)\end{array}$ & $\begin{array}{r}0.005 \\
(0.004)\end{array}$ & $\begin{array}{r}-0.000 \\
(0.006)\end{array}$ \\
\hline $\begin{array}{l}\$ 3,000 \\
(1500 \text { single })\end{array}$ & quintic & $\$ 20,000$ & $\begin{array}{r}-0.007 \\
(0.009)\end{array}$ & $\begin{array}{r}-0.003 \\
(0.006)\end{array}$ & $\begin{array}{r}0.000 \\
(0.008)\end{array}$ & $\begin{array}{r}-0.008 \\
(0.008)\end{array}$ & $\begin{array}{r}0.005 \\
(0.005)\end{array}$ & $\begin{array}{r}0.002 \\
(0.007)\end{array}$ \\
\hline$\$ 0$ & quintic & $\$ 10,000$ & $\begin{array}{r}0.031 \\
(0.006)\end{array}$ & $\begin{array}{r}0.024 \\
(0.004)\end{array}$ & $\begin{array}{r}0.009 \\
(0.005)\end{array}$ & $\begin{array}{r}0.015 \\
(0.008)\end{array}$ & $\begin{array}{r}0.019 \\
(0.005)\end{array}$ & $\begin{array}{r}0.012 \\
(0.006)\end{array}$ \\
\hline $\begin{array}{l}\$ 1,000 \\
(500 \text { single })\end{array}$ & quintic & $\$ 10,000$ & $\begin{array}{r}0.007 \\
(0.010)\end{array}$ & $\begin{array}{r}0.014 \\
(0.006)\end{array}$ & $\begin{array}{r}0.011 \\
(0.008)\end{array}$ & $\begin{array}{r}0.003 \\
(0.010)\end{array}$ & $\begin{array}{r}0.017 \\
(0.006)\end{array}$ & $\begin{array}{r}0.005 \\
(0.008)\end{array}$ \\
\hline $\begin{array}{l}\$ 2,000 \\
(1000 \text { single })\end{array}$ & quintic & $\$ 10,000$ & $\begin{array}{r}0.014 \\
(0.018)\end{array}$ & $\begin{array}{r}0.019 \\
(0.012)\end{array}$ & $\begin{array}{r}0.031 \\
(0.015)\end{array}$ & $\begin{array}{r}-0.000 \\
(0.014)\end{array}$ & $\begin{array}{r}0.010 \\
(0.008)\end{array}$ & $\begin{array}{r}0.003 \\
(0.011)\end{array}$ \\
\hline $\begin{array}{l}\$ 3,000 \\
(1500 \text { single })\end{array}$ & quintic & $\$ 10,000$ & $\begin{array}{r}-0.043 \\
(0.037)\end{array}$ & $\begin{array}{r}0.019 \\
(0.023)\end{array}$ & $\begin{array}{r}0.008 \\
(0.029)\end{array}$ & $\begin{array}{r}-0.008 \\
(0.018)\end{array}$ & $\begin{array}{r}0.014 \\
(0.011)\end{array}$ & $\begin{array}{r}0.015 \\
(0.015)\end{array}$ \\
\hline$\$ 0$ & quartic & $\$ 20,000$ & $\begin{array}{r}0.019 \\
(0.003)\end{array}$ & $\begin{array}{r}0.006 \\
(0.002)\end{array}$ & $\begin{array}{r}0.008 \\
(0.003)\end{array}$ & $\begin{array}{r}0.002 \\
(0.005)\end{array}$ & $\begin{array}{r}0.004 \\
(0.003)\end{array}$ & $\begin{array}{r}0.005 \\
(0.004)\end{array}$ \\
\hline $\begin{array}{l}\$ 1,000 \\
(500 \text { single) }\end{array}$ & quartic & $\$ 20,000$ & $\begin{array}{r}0.010 \\
(0.004)\end{array}$ & $\begin{array}{r}-0.002 \\
(0.002)\end{array}$ & $\begin{array}{r}0.008 \\
(0.003)\end{array}$ & $\begin{array}{r}-0.004 \\
(0.005)\end{array}$ & $\begin{array}{r}0.001 \\
(0.003)\end{array}$ & $\begin{array}{r}0.002 \\
(0.004)\end{array}$ \\
\hline $\begin{array}{l}\$ 2,000 \\
(1000 \text { single })\end{array}$ & quartic & $\$ 20,000$ & $\begin{array}{r}0.013 \\
(0.005)\end{array}$ & $\begin{array}{r}-0.005 \\
(0.003)\end{array}$ & $\begin{array}{r}0.010 \\
(0.004)\end{array}$ & $\begin{array}{r}-0.005 \\
(0.006)\end{array}$ & $\begin{array}{r}-0.003 \\
(0.003)\end{array}$ & $\begin{array}{r}0.001 \\
(0.005)\end{array}$ \\
\hline $\begin{array}{l}\$ 3,000 \\
(1500 \text { single })\end{array}$ & quartic & $\$ 20,000$ & $\begin{array}{r}0.008 \\
(0.006)\end{array}$ & $\begin{array}{r}-0.009 * * \\
(0.004)\end{array}$ & $\begin{array}{r}0.006 \\
(0.005)\end{array}$ & $\begin{array}{r}-0.007 \\
(0.006)\end{array}$ & $\begin{array}{r}-0.004 \\
(0.004)\end{array}$ & $\begin{array}{r}0.003 \\
(0.005)\end{array}$ \\
\hline$\$ 0$ & quartic & $\$ 10,000$ & $\begin{array}{r}0.024 \\
(0.005)\end{array}$ & $\begin{array}{r}0.017 \\
(0.003)\end{array}$ & $\begin{array}{r}0.008 \\
(0.004)\end{array}$ & $\begin{array}{r}0.012 \\
(0.007)\end{array}$ & $\begin{array}{r}0.013 \\
(0.004)\end{array}$ & $\begin{array}{r}0.007 \\
(0.005)\end{array}$ \\
\hline $\begin{array}{l}\$ 1,000 \\
(500 \text { single })\end{array}$ & quartic & $\$ 10,000$ & $\begin{array}{r}0.007 \\
(0.007)\end{array}$ & $\begin{array}{r}0.006 \\
(0.004)\end{array}$ & $\begin{array}{r}0.008 \\
(0.006)\end{array}$ & $\begin{array}{r}0.004 \\
(0.008)\end{array}$ & $\begin{array}{r}0.009 \\
(0.005)\end{array}$ & $\begin{array}{r}0.000 \\
(0.007)\end{array}$ \\
\hline $\begin{array}{l}\$ 2,000 \\
(1000 \text { single })\end{array}$ & quartic & $\$ 10,000$ & $\begin{array}{r}0.011 \\
(0.011)\end{array}$ & $\begin{array}{r}0.003 \\
(0.007)\end{array}$ & $\begin{array}{r}0.013 \\
(0.009)\end{array}$ & $\begin{array}{r}0.003 \\
(0.010)\end{array}$ & $\begin{array}{r}0.003 \\
(0.006)\end{array}$ & $\begin{array}{r}-0.002 \\
(0.008)\end{array}$ \\
\hline $\begin{array}{l}\$ 3,000 \\
(1500 \text { single })\end{array}$ & quartic & $\$ 10,000$ & $\begin{array}{r}-0.010 \\
(0.017)\end{array}$ & $\begin{array}{r}-0.005 \\
(0.011)\end{array}$ & $\begin{array}{r}-0.005 \\
(0.014)\end{array}$ & $\begin{array}{r}0.001 \\
(0.011)\end{array}$ & $\begin{array}{r}0.003 \\
(0.007)\end{array}$ & $\begin{array}{r}0.002 \\
(0.010)\end{array}$ \\
\hline
\end{tabular}

Notes are the same those attached to Table 5. 
Appendix Table 6

Effect of the DTF Threshold on Attending Four-Year College (conditional on attending at all) in Year 1

\begin{tabular}{|c|c|c|c|c|c|c|c|c|}
\hline & $\begin{array}{r}2002 \& \\
2003 \\
\text { cohorts }\end{array}$ & \multicolumn{2}{|c|}{$\begin{array}{r}2004 \text { through } 2008 \\
\text { cohorts }\end{array}$} & $\begin{array}{r}2002 \& \\
2003 \\
\text { cohorts }\end{array}$ & \multicolumn{2}{|c|}{$\begin{array}{r}2004 \text { through } 2008 \\
\text { cohorts }\end{array}$} \\
\hline & & & $\begin{array}{l}\$ 130,000 \\
\text { threshold }\end{array}$ & $\begin{array}{l}\$ 130,000 \\
\text { threshold }\end{array}$ & $\begin{array}{l}\$ 160,000 \\
\text { threshold }\end{array}$ & $\begin{array}{r}\$ 65,000 \\
\text { threshold }\end{array}$ & $\begin{array}{r}\$ 65,000 \\
\text { threshold }\end{array}$ & $\begin{array}{r}\$ 80,000 \\
\text { threshold }\end{array}$ \\
\hline \multicolumn{3}{|c|}{$\begin{array}{l}\text { base case (unlikely to be biased by } \\
\text { income management) }\end{array}$} & $\begin{array}{r}-0.003 \\
(0.010)\end{array}$ & $\begin{array}{r}-0.002 \\
(0.006)\end{array}$ & $\begin{array}{r}0.001 \\
(0.008)\end{array}$ & $\begin{array}{r}0.007 \\
(0.011)\end{array}$ & $\begin{array}{r}0.002 \\
(0.007)\end{array}$ & $\begin{array}{r}0.003 \\
(0.009)\end{array}$ \\
\hline \multicolumn{9}{|l|}{ Other cases } \\
\hline $\begin{array}{l}\text { doughnut } \\
\text { hole }\end{array}$ & $\begin{array}{l}\text { poly- } \\
\text { nomial }\end{array}$ & $\begin{array}{l}\text { band- } \\
\text { width }\end{array}$ & & & & & & \\
\hline$\$ 0$ & quintic & $\$ 20,000$ & $\begin{array}{r}0.027 \\
(0.006)\end{array}$ & $\begin{array}{r}0.014 \\
(0.004)\end{array}$ & $\begin{array}{r}0.008 \\
(0.005)\end{array}$ & $\begin{array}{r}0.009 \\
(0.009)\end{array}$ & $\begin{array}{r}0.008 \\
(0.005)\end{array}$ & $\begin{array}{r}0.006 \\
(0.007)\end{array}$ \\
\hline $\begin{array}{l}\$ 1,000 \\
(500 \text { single })\end{array}$ & quintic & $\$ 20,000$ & $\begin{array}{r}0.019 \\
(0.008)\end{array}$ & $\begin{array}{r}0.004 \\
(0.005)\end{array}$ & $\begin{array}{r}-0.000 \\
(0.006)\end{array}$ & $\begin{array}{r}0.006 \\
(0.010)\end{array}$ & $\begin{array}{r}0.007 \\
(0.006)\end{array}$ & $\begin{array}{r}0.003 \\
(0.008)\end{array}$ \\
\hline $\begin{array}{l}\$ 2,000 \\
(1000 \text { single })\end{array}$ & quintic & $\$ 20,000$ & $\begin{array}{r}-0.003 \\
(0.010)\end{array}$ & $\begin{array}{r}-0.002 \\
(0.006)\end{array}$ & $\begin{array}{r}0.001 \\
(0.008)\end{array}$ & $\begin{array}{r}0.007 \\
(0.011)\end{array}$ & $\begin{array}{r}0.002 \\
(0.007)\end{array}$ & $\begin{array}{r}0.003 \\
(0.009)\end{array}$ \\
\hline $\begin{array}{l}\$ 3,000 \\
(1500 \text { single })\end{array}$ & quintic & $\$ 20,000$ & $\begin{array}{r}-0.002 \\
(0.015)\end{array}$ & $\begin{array}{r}0.009 \\
(0.009)\end{array}$ & $\begin{array}{r}0.006 \\
(0.011)\end{array}$ & $\begin{array}{r}-0.005 \\
(0.013)\end{array}$ & $\begin{array}{r}-0.004 \\
(0.008)\end{array}$ & $\begin{array}{r}-0.005 \\
(0.010)\end{array}$ \\
\hline$\$ 0$ & quintic & $\$ 10,000$ & $\begin{array}{r}0.048 \\
(0.009)\end{array}$ & $\begin{array}{r}0.022 \\
(0.005)\end{array}$ & $\begin{array}{r}0.015 \\
(0.007)\end{array}$ & $\begin{array}{r}0.017 \\
(0.012)\end{array}$ & $\begin{array}{r}0.013 \\
(0.007)\end{array}$ & $\begin{array}{r}0.015 \\
(0.010)\end{array}$ \\
\hline $\begin{array}{l}\$ 1,000 \\
(500 \text { single })\end{array}$ & quintic & $\$ 10,000$ & $\begin{array}{r}0.053 \\
(0.015)\end{array}$ & $\begin{array}{r}0.003 \\
(0.009)\end{array}$ & $\begin{array}{r}-0.004 \\
(0.012)\end{array}$ & $\begin{array}{r}0.016 \\
(0.016)\end{array}$ & $\begin{array}{r}0.012 \\
(0.010)\end{array}$ & $\begin{array}{r}0.012 \\
(0.013)\end{array}$ \\
\hline $\begin{array}{l}\$ 2,000 \\
(1000 \text { single })\end{array}$ & quintic & $\$ 10,000$ & $\begin{array}{r}0.009 \\
(0.028)\end{array}$ & $\begin{array}{r}-0.030 \\
(0.017)\end{array}$ & $\begin{array}{l}-0.015 \\
(0.022)\end{array}$ & $\begin{array}{r}0.025 \\
(0.022)\end{array}$ & $\begin{array}{r}0.003 \\
(0.013)\end{array}$ & $\begin{array}{r}0.016 \\
(0.017)\end{array}$ \\
\hline $\begin{array}{l}\$ 3,000 \\
(1500 \text { single })\end{array}$ & quintic & $\$ 10,000$ & $\begin{array}{r}0.009 \\
(0.057)\end{array}$ & $\begin{array}{r}-0.003 \\
(0.034)\end{array}$ & $\begin{array}{r}-0.032 \\
(0.043)\end{array}$ & $\begin{array}{r}-0.004 \\
(0.029)\end{array}$ & $\begin{array}{r}-0.021 \\
(0.017)\end{array}$ & $\begin{array}{r}-0.002 \\
(0.023)\end{array}$ \\
\hline$\$ 0$ & quartic & $\$ 20,000$ & $\begin{array}{r}0.010 \\
(0.006)\end{array}$ & $\begin{array}{r}0.010 \\
(0.003)\end{array}$ & $\begin{array}{r}0.006 \\
(0.004)\end{array}$ & $\begin{array}{r}0.005 \\
(0.007)\end{array}$ & $\begin{array}{r}0.006 \\
(0.004)\end{array}$ & $\begin{array}{r}0.001 \\
(0.006)\end{array}$ \\
\hline $\begin{array}{l}\$ 1,000 \\
(500 \text { single })\end{array}$ & quartic & $\$ 20,000$ & $\begin{array}{r}-0.007 \\
(0.008)\end{array}$ & $\begin{array}{r}0.003 \\
(0.004)\end{array}$ & $\begin{array}{r}-0.001 \\
(0.005)\end{array}$ & $\begin{array}{r}0.003 \\
(0.008)\end{array}$ & $\begin{array}{r}0.005 \\
(0.005)\end{array}$ & $\begin{array}{r}-0.003 \\
(0.006)\end{array}$ \\
\hline $\begin{array}{l}\$ 2,000 \\
(1000 \text { single })\end{array}$ & quartic & $\$ 20,000$ & $\begin{array}{r}-0.008 \\
(0.010)\end{array}$ & $\begin{array}{r}-0.001 \\
(0.004)\end{array}$ & $\begin{array}{r}0.000 \\
(0.006)\end{array}$ & $\begin{array}{r}0.002 \\
(0.009)\end{array}$ & $\begin{array}{r}0.002 \\
(0.005)\end{array}$ & $\begin{array}{r}-0.004 \\
(0.007)\end{array}$ \\
\hline $\begin{array}{l}\$ 3,000 \\
(1500 \text { single })\end{array}$ & quartic & $\$ 20,000$ & $\begin{array}{r}0.004 \\
(0.007)\end{array}$ & $\begin{array}{r}0.006 \\
(0.006)\end{array}$ & $\begin{array}{r}0.003 \\
(0.007)\end{array}$ & $\begin{array}{r}-0.006 \\
(0.010)\end{array}$ & $\begin{array}{r}-0.003 \\
(0.006)\end{array}$ & $\begin{array}{r}-0.010 \\
(0.008)\end{array}$ \\
\hline$\$ 0$ & quartic & $\$ 10,000$ & $\begin{array}{r}0.037 \\
(0.007)\end{array}$ & $\begin{array}{r}0.019 \\
(0.004)\end{array}$ & $\begin{array}{r}0.009 \\
(0.006)\end{array}$ & $\begin{array}{r}0.013 \\
(0.010)\end{array}$ & $\begin{array}{r}0.009 \\
(0.006)\end{array}$ & $\begin{array}{r}0.016 \\
(0.008)\end{array}$ \\
\hline $\begin{array}{l}\$ 1,000 \\
\text { (500single) }\end{array}$ & quartic & $\$ 10,000$ & $\begin{array}{r}0.033 \\
(0.011)\end{array}$ & $\begin{array}{r}0.007 \\
(0.006)\end{array}$ & $\begin{array}{r}-0.006 \\
(0.008)\end{array}$ & $\begin{array}{r}0.011 \\
(0.012)\end{array}$ & $\begin{array}{r}0.007 \\
(0.007)\end{array}$ & $\begin{array}{r}0.015 \\
(0.010)\end{array}$ \\
\hline $\begin{array}{l}\$ 2,000 \\
(1000 \text { single })\end{array}$ & quartic & $\$ 10,000$ & $\begin{array}{r}-0.005 \\
(0.027)\end{array}$ & $\begin{array}{r}-0.004 \\
(0.010)\end{array}$ & $\begin{array}{r}-0.010 \\
(0.013)\end{array}$ & $\begin{array}{r}0.014 \\
(0.015)\end{array}$ & $\begin{array}{r}0.000 \\
(0.009)\end{array}$ & $\begin{array}{r}0.019 \\
(0.012)\end{array}$ \\
\hline $\begin{array}{l}\$ 3,000 \\
(1500 \text { single })\end{array}$ & quartic & $\$ 10,000$ & $\begin{array}{r}0.018 * * * \\
(0.005)\end{array}$ & $\begin{array}{r}0.021 \\
(0.016)\end{array}$ & $\begin{array}{r}-0.009 \\
(0.020)\end{array}$ & $\begin{array}{r}-0.004 \\
(0.018)\end{array}$ & $\begin{array}{r}-0.013 \\
(0.011)\end{array}$ & $\begin{array}{r}0.012 \\
(0.015)\end{array}$ \\
\hline
\end{tabular}

Notes are the same as those attached to Table 6 . 